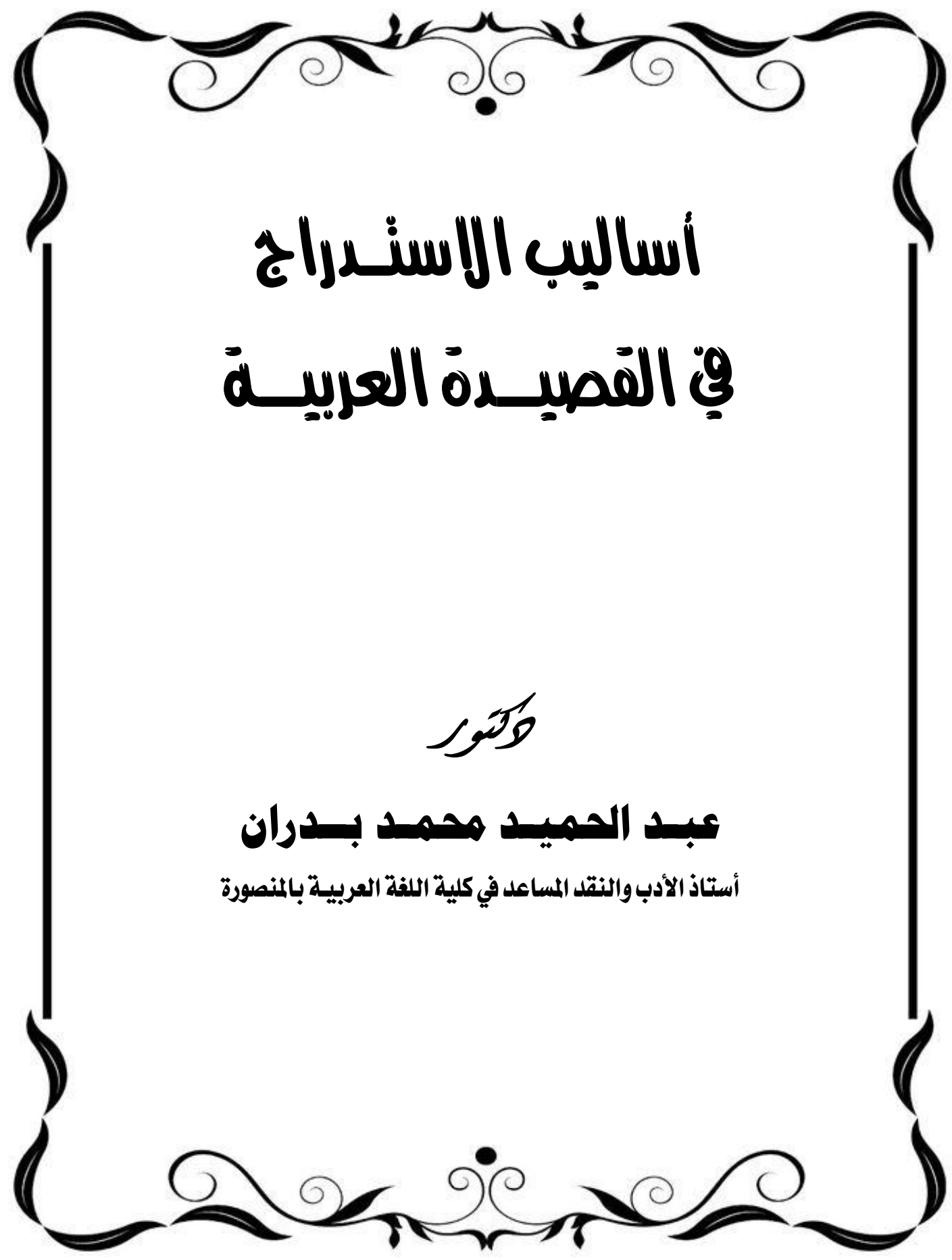




$$
\text { بـ عبدالميدمحد بلران }
$$

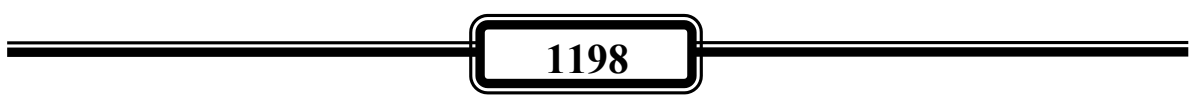




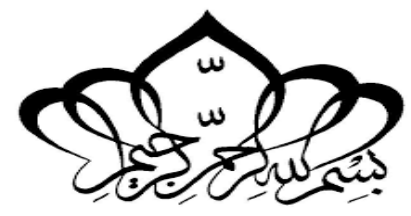

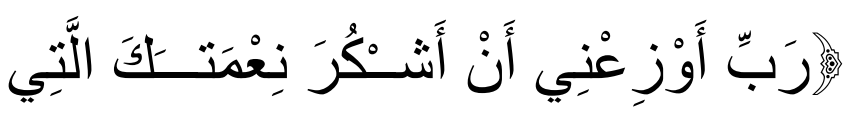

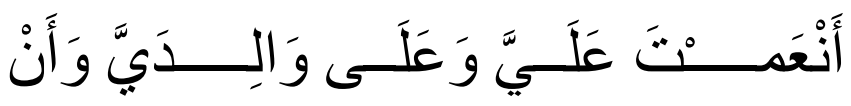

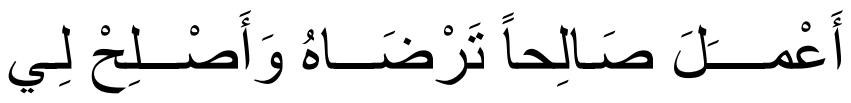

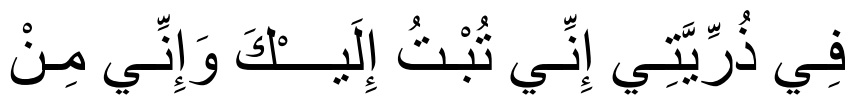

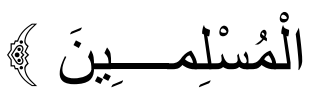

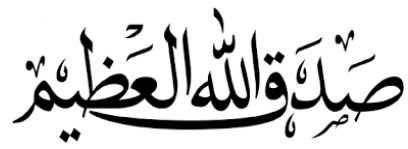




$$
\text { بـ عبدالميدمحد بلران }
$$




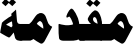

لا نبالغ إذا قلنا إن تقنية الاستدراج في القصيدة العربية كانت تقنية جهيرة وواسعة الثـهرة في أدبنـا العريـي القديم ، ويخاصـة مـع اعتمـاد الثـاعر العربي على مجموعة من المسلمات التي كان يحاول توظيفها ببراعة في كثير من قصائدة ، بغية ذيوع شعره وإنتشاره .

وإذا كان بنـاء القصيلة العربية القديمة قد اشتهر بانحصـاره في البنـاء الغنائي والبناء القصصي ـ فإن تقنية الاستدراج في القصيدة العربية يمكن

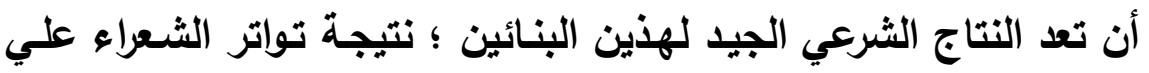

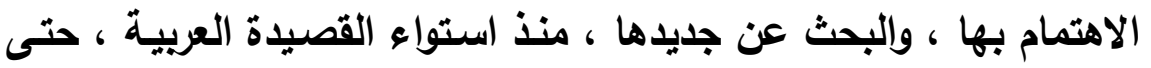
الثعر العربي الحديث المعتمد على التفعيلة ، مما يؤكد أن الاستدراج كان لونا من الألوان التجديدية التي حفظت للقصيدة العربية حيويتها ، وأكدات أن حركتها في كل ألوان التجديد كانت حركة بنائية فنية منضبطة الأطر

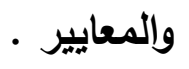

ومسن ثم كانت ملاحظة الاستـاج في القصيلة العربية ملاحظة جديرة

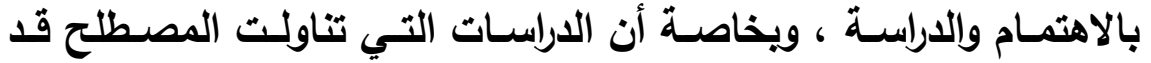
حلدته في إطـار بلاغي يحجم مـن فضـاء|ته الثـعرية الإيحائيسة (1) ، ويحصـره في كونـهـ قيمـة مـن القيم البلاغيـة التـي تـدور عليهـا الكتابـة

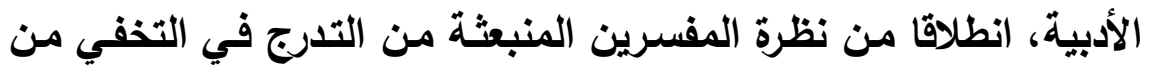
أجل تحقيق المباغتة المهلكة ، كما بدا في تفسيرهم قول الله جل وعزّ :

(1) من الدراسات البلاغية الجيدة التي تناولت مقامات الاستدر اج في القران

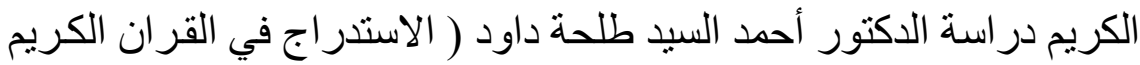

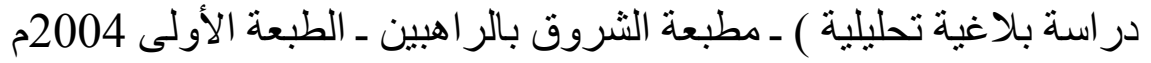




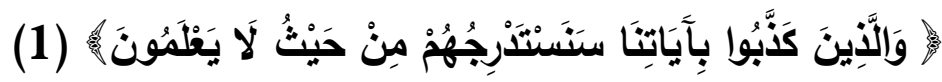

وقد اقتضت طبيعة الدراسـة أن يتم تتبع صورة القصيدة العربيـة القديمـة والحديثة ، التي تعنسى بتطور الحـدث وتتامبـه ، أو التي تعنسى بتعـدد الأغراض في القصيدة الواحدة ، من أجل الوقوف على أهم الأنماط التي

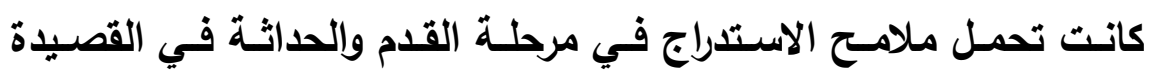
العربية، ومن ثم كان تقسيم البحث إلى خمسة مباحث : المبحث الأول (مصطلح الاستدراج) وفيه تتبعت معنى مصطلح الاستدراج عند اللغويين والمفسرين والبلاغيين واللنقاد ، بغيـة الوصول إلى تحديـ فني واضح للمصطلح ، من خلال فقه أبعاده التي يرمسي إليها في حركية القصيدة العربية ، وتحديد الأساليب التي يمكن أن يدور عليها المصطلح فـي المبحـث الثـاني (مقدمـة القصـيدة) ، والمبحـث الثالــث (النهايــة المفاجئة)، والمبحث الرابع (الارتداد)، والمبحث الخامس (المفارقة). على ألا يظن ـ في النهاية ـ أن هذه الأسـاليب هي كل مـا يمكن أن يشكل

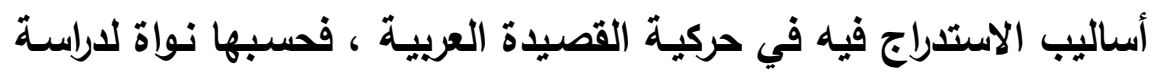
كبيرة تحتاج إلى مزيد من العمق والاستقصاء ، ونأمل في هذه الدراسـة أن نؤكـــ على حيويـة القصيدة العربيـة القديمـة التـي رميت كثيـرا بـالجمود والتقليدية ، وأن نثبت أنها ما زالت قادرة ـ حتى في إطارها التقليدي ـ على

حمل كثير من القوالب القنية التي تحفظ لها حيويتها ونماءها ـ

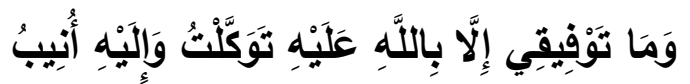

(1) الأعراف : 182 


\section{همسطح الاستمدراج}

الاستيدراج عند اللغويسين :

يدور المعنى اللغوي لمادة (درج) حول معنيين هما الطي والارتقاء ، غير أن الاستدراج كثيرا ما كان يستأثر بالمعنى الثاني ، حيث دار حول معنى التدرج حتى بلوغ الغاية ، على ما يبدو مثلا من قول الزمخثري : " وهذه آثـار قـوم درجـوا : انقرضـوا ، ودرج فـلان : (مـات ومــا تـرك نسـلاً) ... واستدرجه : (رقّاه من درجة إلى درجة) ، وقيل استدعى هلكته من درج إذا لمات

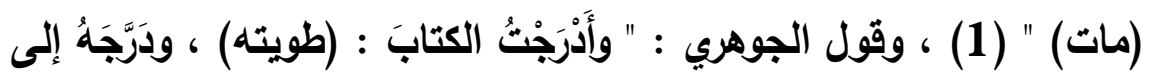

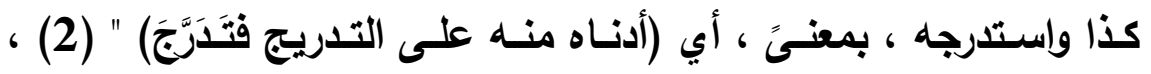

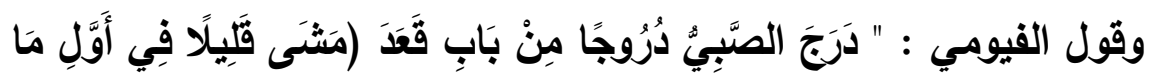

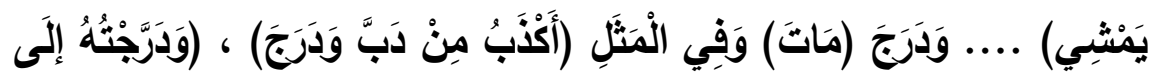

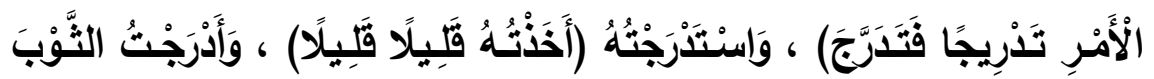

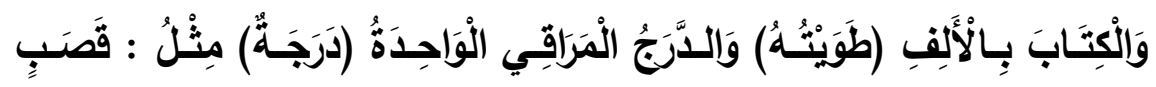

وَقَََصَبَةِ "(3)

إلا أن كثيرا من اللغويين قد أدركوا في التركيب أيضـا ملامـح جديدة تحمل

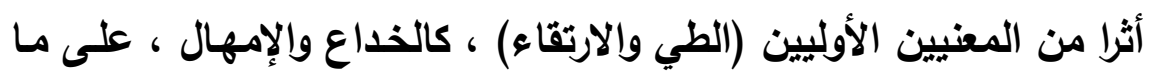

(1) أسـاس البلاغــة ـ أبـو القاسـم محمـود بـن عمـر بـن محمــــــن عمـر

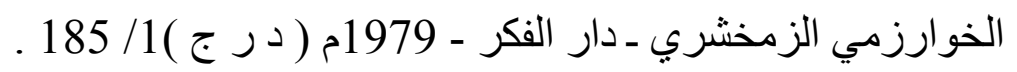

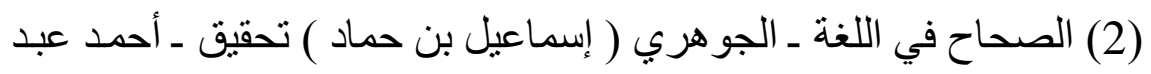

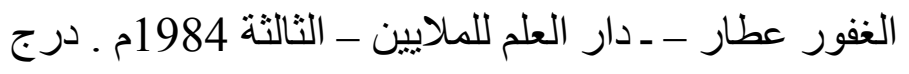

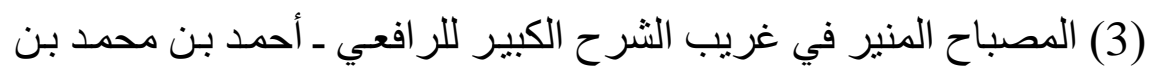

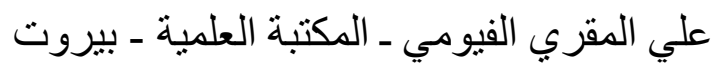


يبدو ـ مثثلا ـ من قول الأزهري : " وقال الله جل وعز : (سَتَسْتَتْرِجُهُهْ مِنْ

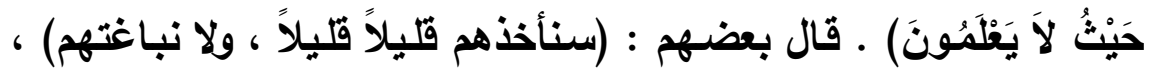
وأخبرني المنذري عن أبي الهيثم أنه قال : يقال : امتنع فلان من كذا وكذا

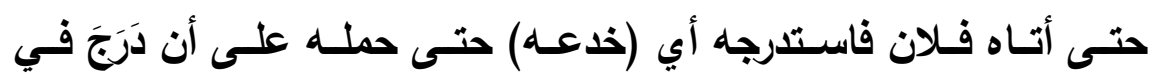

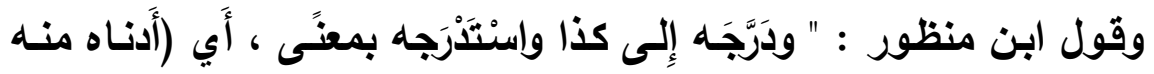

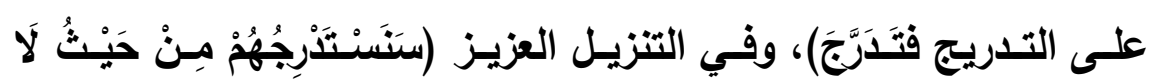

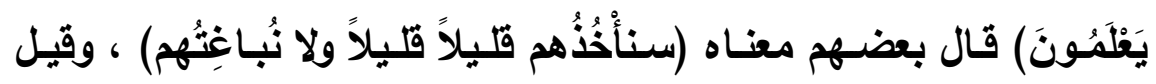
معناه (سنأْذذهم من حيث لا يحتسبون) ، وذلك أَن الله تعالى يفتح عليهم

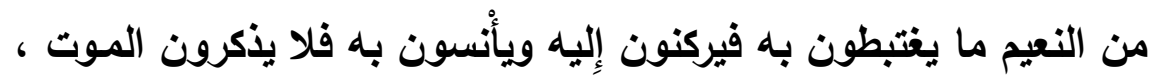

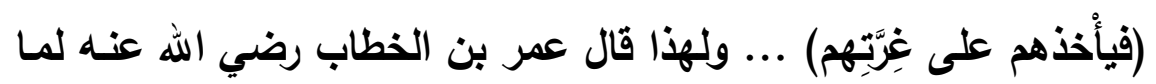

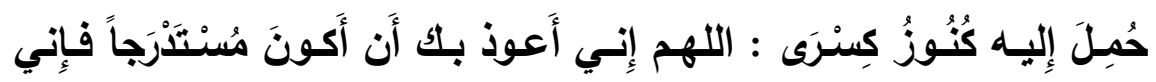

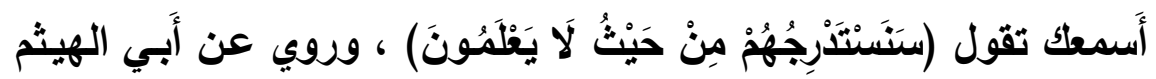

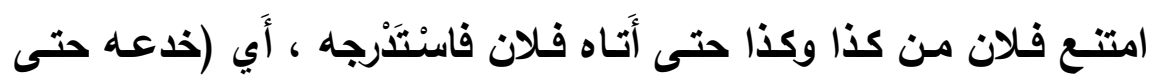

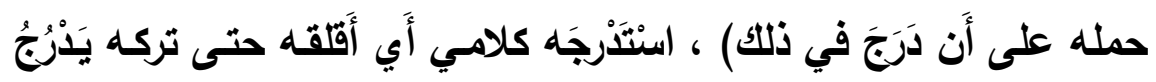

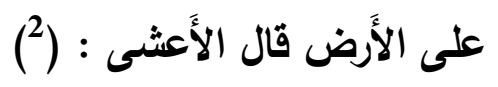

(1) تهذيب اللغـة ـ أبو منصـور محمد بن أحمد الأزهري ـ تحقيق ـ محمد

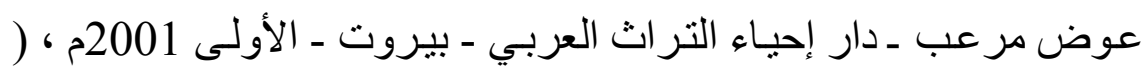
درج (2) (2)

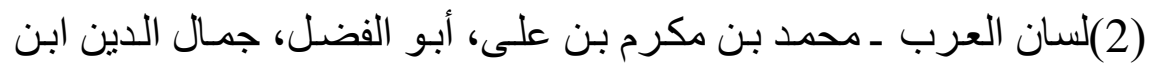
منظور الأنصـاري الرويفعى الإفريقى (711هـ) دار صـادر - بيـروت :

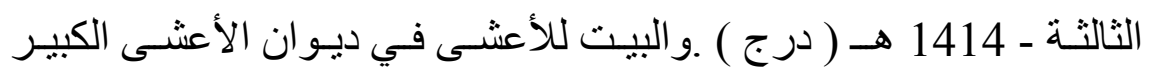




\section{إصدار 2017}

حولية كلية اللغة العربية بالمنوفية العدد الثاني والثلاثون

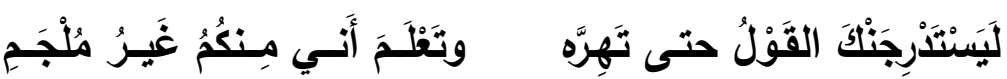

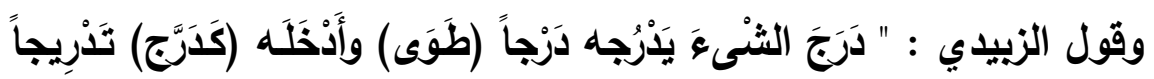

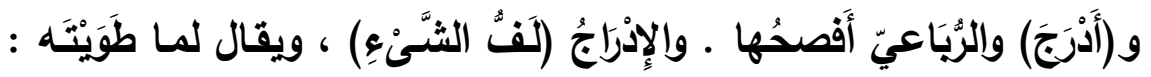

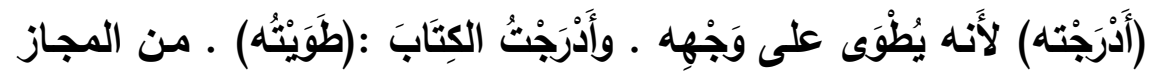

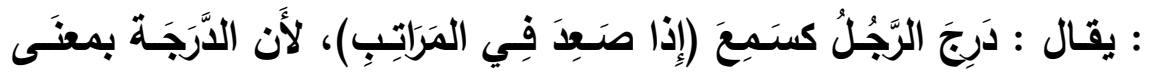

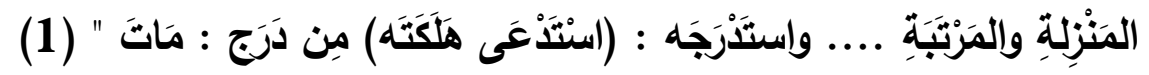
وواضح من روئة ابن منظور والأبيدي سيطرة معنى الاستدراج المـأخوذ

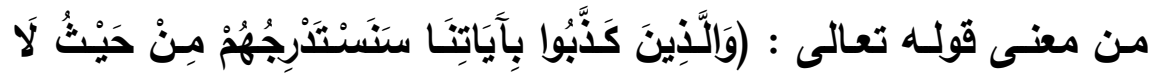

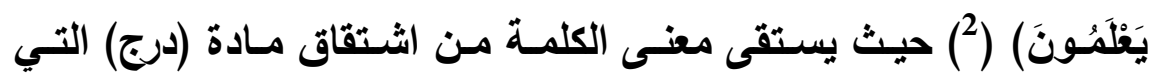

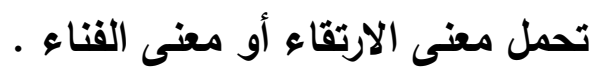

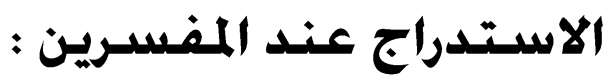
إذا كانت نظرة اللغويين قد وقفت بالاستدراج عند حدود المعنى اللغوي . فإن نظرة المفسرين قد وضعت له أطرا وضوابط ، نستطيع من خلالها أن نقف على مصطلح نقدي جيد مكتمل الملامـح ، على هدى بالطبع مما يوحي بـه أصل الوضع اللغوي ، حيث وقف المفسرون وقفات جيدة مـع تفسير معنى الاستدراج في القران الكريم ، يبدو ذلك من قول الطبري : "

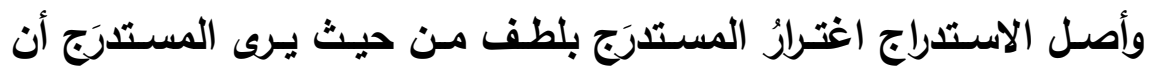

تحقيق د. محمود إبر اهيم محمد الرضو اني ـ وزارة التقافـة والفنون و التراث

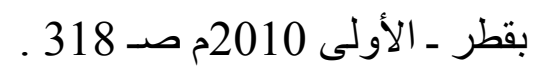

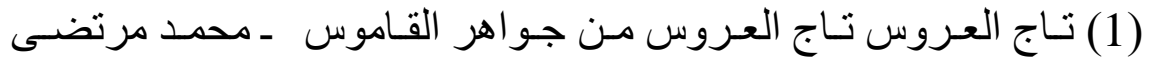

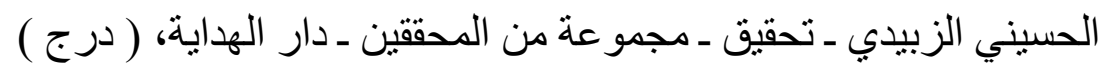

$$
\text { (2) سورة الأعر اف من الآية } 182 .
$$


المستثدرج إليه محسنٌ ، حتى يورِّطه مكروهًا. "(1) وقول البغوي : " قال أهل المعاني : الاستدراج (أن يتدرج إلى الشسيء في خفية قليلا قليلا فلا يباغت ولا يجاهر) ، ومنه درج الصبي إذا (قارب بين خطاه في المشي) ، ومنه درج الكتاب إذا (طواه شيئا بعد شيء) ." (2) وقول أبي حيان : وقال أبو عبيدة : الاستدراج (أن تدرج إلى الشسيع في خفية قليلاً قليلاً ولا تهجم عليه) ، وأصله من الارجة ، وذلك أنّ (الراقي والنـازل يرقى وينزل مرقاة مرقاة) ، ومنـه درج الكتـاب (طواه شـيئاً بعد شيء) ، ودرج القوم (ماتوا بعضهم في أثر بعض) (3)

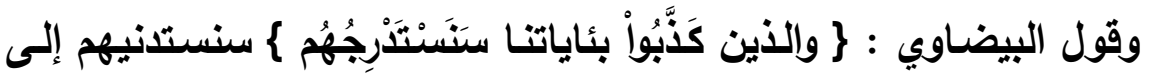
الهـلاك قليلاً قليلاً ، وأصل الاستدراج الاستصعاد أو الاستنزال درجة بعد درجة. \} مّنْ حَيْثُ لَا يَعْلَمُونَ \{ ما نريد بهم وذلكَ أن تتواتر عليهم النعم فيظنوا أنها لطف من الله تعسالى بهم ، فيزدادوا بطراً وانهمـاكاً في الغي حتى يحق عليهم كلمـة العـاب.(4)

(1) جامع البيان عن تأويل آي القرآن ـ محمد بن جرير بن يزيد بن خالد

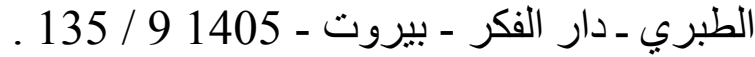

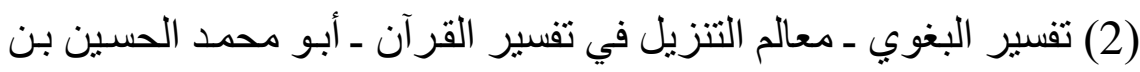

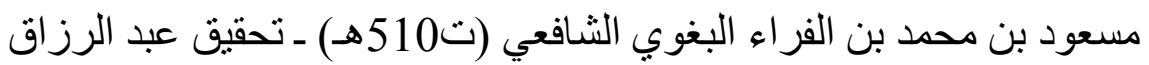

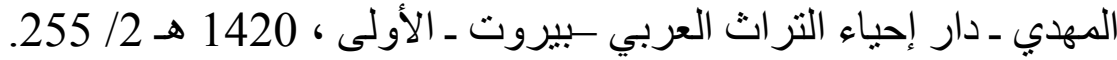

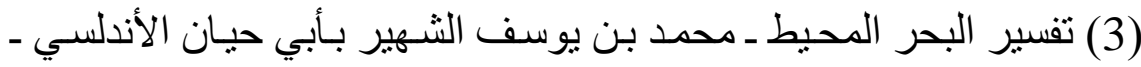
تحقيق ـ عادل أحمد عبد الموجود ـ علي محمد معوض ـ دار الكتب العلمية ـ

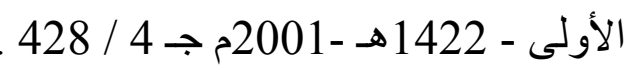

(4) تفسير البيضـاوي ـ ناصـر الدين أبو الخير عبد الله بن عمر بن محمد

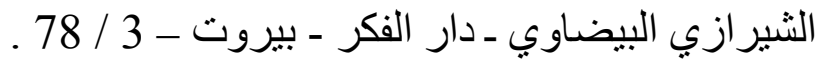


وقول الزمخشري : الاستدراج : (استفعال من الارجة بمعنى الاستصعاد) ،

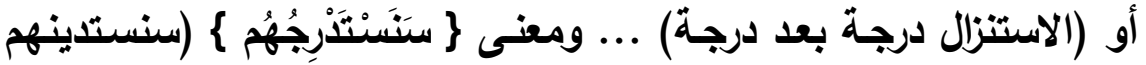

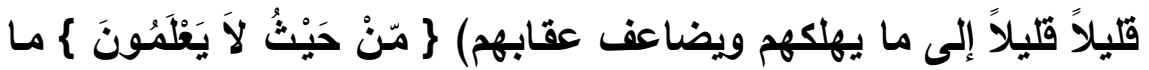
يراد بهم ، وذلك أن يواتر الله نعمه عليهم مـع انهماكهم في الغيّ ـ فكلّمـا جدّد عليهم نعمـة ازدادوا بطراً وجدّدوا معصية ، فيتدرّجون في المعاصسي بسبب ترادف النعم ، ظانين أنّ مواترة النعم أثرة من الله وتقريب ، وإنما هي (خذلان منه وتبعيد) ، فهو استدراج الله تعالى (1) وقول العز بن عبد السـلام : " الاستدراج : (أن يأتي الشيء من حيث لا يعلم) ، أو أن (ينطوي منزلة بعد منزلة) ، من اللدرج لانطوائهه على شيء بعد شيء ، أو من الدرجة لانحطاطه عن منزلـة بعد منزلة ، يستدرجون إلى الكفز ، أو إلى الهلكة بالإمداد بالنعم ونسيان الشكر ، أو كلمـا أحدثوا

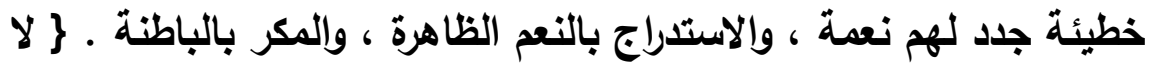

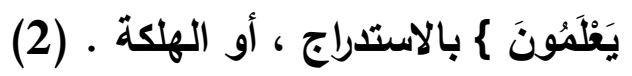

وواضح من روئية المفسرين أن الاغترار بلطف ، وعدم المجاهرة والمباغتة ، وعدم الهجوم ، والاستدناء ، والظن أو عدم العلم ـ كل هذه المعاني كان

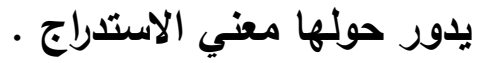

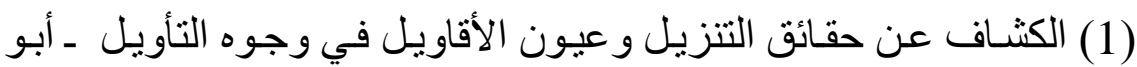

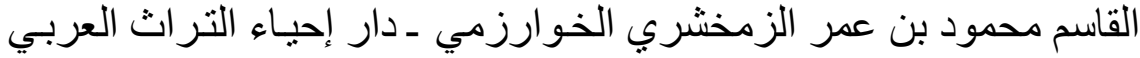
- بيروت ـ تحقيق ـ عبد الرزاق المهدي 2 / 171 ـ و الثطر الأول من البيت

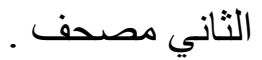
(2) تفسير القرآن / اختصـار النكت للماوردي ـ الإمام عز الدين عبد العزيز بن عبد السـلام السـلمي الدمشقي الثـافعي ـ تحقيق ــ ــ ـ عبد الله بن إبر اهيم

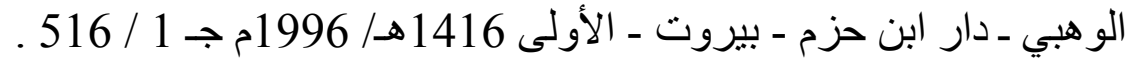


فإذا مـا وصلنا إلى تفسير الألوسي وأبسي السعود والطاهر بن عاشور . وجدنا أن هناك تظورا في نظرة المفسرين لمعنى الاستدراج ، حيث انتقل معنى الاستدراج على يل هؤلاء من مجرد التدرج صعودا وهبوطا ، كما هو عند اللغويين ، أو ملاحظة جانب المخاتلـة والمخادعة ، كمـا هو الحسال عند المفسرين القدامى ـ انتقل معنى الاستدراج إلى (محاولية وضـع إطار عام ينضبط به المصطلح) ، بحيث يمكن أن يكون المعنى تمثيلا لكل من قصد تغيير حالة دون إثعار صاحبها صراحة بهذا التغيير ، كما يبدو من قول الطاهر بن عاشور : " والاستدراج مشتق من الآرَجة بفتحتين وهي

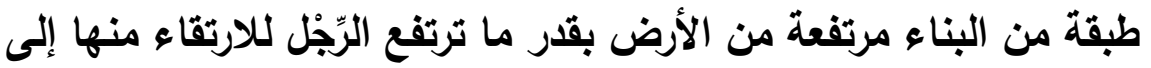
مـا فوقها ، تيسيراً للصـود في مثل العلو أو الصـومعة أو البرج .... ، فالسين والتـاء في فعل الاستـراج للطلب ، أي طلب منـه أن يتدرج ، أي صـاعداً أو نـازلاً ، والكـلام تمثيل لحال القاصد إبدال حال أحـ إلى غيرهـا بدون إثـعاره . بحال من يطلب من غيره أن ينزل من درجة إلى أخرى بحيث ينتهي إلى المكان الأي لا يستطيع الوصول إليهه بدون ذلك ، وهو تمثيل بليع يشتمل على تشبيهات كثيرة ، فإنـه مبني على تشبيه حُسن الحال برفعة المكان وضده بسفالة المكان ، والقرينة تعيّن المقصود من

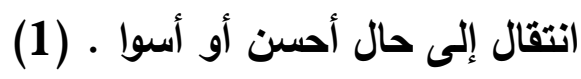

ويمكن أن يكون المعنى مستعارا من كل نقل تدريجي يتم موافقا لهوى المستثرج ، وإن كان ظاهره مخالفا لباطنه ، كما يبدو من قول الالوسي: " والاستدراج استفعال من الارجة بمعنى النقل درجة بعد درجة من سفل إلى

(1) التحرير والتنوير - محمد الطـاهر بن عاشور ـ الدار التونسية للنشر

$$
\text { 1984م - ج } 9 \text { / ص ص } 191
$$


علو فيكون استصعاداً أو بالعكس فيكون استنزالاً .... وقال بعضهم : هو استفعال من درجة إمـا بمعنى صسد ثم اتسـع فيـه فاستعمل في كل نقل تـديجي ، سـواء أكسان بطريـق الصـعود أو الهبـوط أو الاسـتقامة ، وإمـا بمعنى مشى مشياً ضعيفاً ومنه درج الصبي ، وإما بمعنى طوى ومنه أدرج الكتاب ، ثم استعير لطلب كل نقل تلريجي من حال إلى حال من الأحوال الملائمـة للمنتقل الموافقـة لهـواه ، واسـتدراجه تعـالى إيـاهم بـإدرار النعم عليهم مع إنهماكهم في الغي ، ولذا قيل : إذا أيـ الله تعالى أنعم على عبد وهو مقيم على معصيته فاعلم أنه مستدرج • (1)

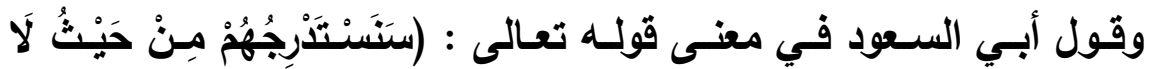

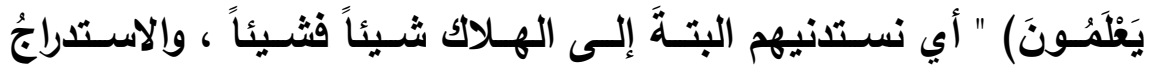
استفعالٌ من درَجَ إمـا بمعنى صـد ثُم اتُسـع فيـه فاستُعمل في كل (نقل تدريجي) سواءُ أكان بطريق الصعودِ أو الهبوط أو الاستقامة ، وإما بمعنى (مشى مشياً ضعيفاً) ، وإمـا بمعنى (طوَى) ، والأولُ هو الأنسبُ بـالمعنى المرادِ الأي هو النقلُ إلى أعلى درجاتِ المهالكِ ليبلُغ أقصى مراتبِ العقوية والعذاب ، ثم استعير لطلب كل نقل تدريجيَ من حال إلى حال من الأحوال الملائمةِ للمنتقل الموافقةِة لهواه بحيث يزعُم أن ذلك ترق في مراقي منافِعه مع أنه في الحقيقة ترد في مهاوي مصارعِه ، فاستدراجُه سبحانه إياهم أن

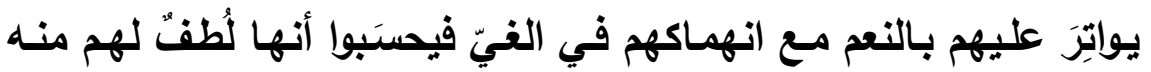
تعالى فيزدادوا بطراً وطغياناً ، لكن لا على أن المطلوبَ تدرُّجُهم في مراتب

(1)روح المعـاني في تفسير القرآن العظيم و السبع المثناني ـ شـهاب الدين

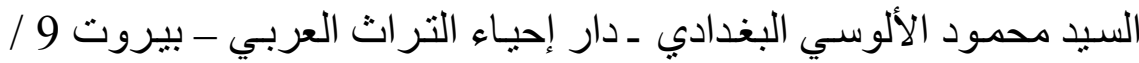




\section{أساليب الاستـــراج في القصيـــة العربيـة}

النعمُ بل هو تدرجُهم في مدارج المعاصي إلى أن يحِقَّ عليهم كلمةُُ العذاب

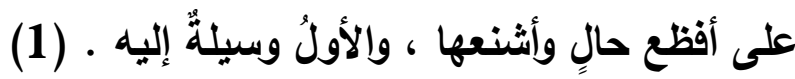

\section{الالسـتدراج عند البلاغيسين والن:قماد :}

بذل البلاغيون والنقاد محاولات جادة من أجل الوصول إلى تحديد جيد للمصطلح ، من حيث التركيز على أسسـه التي لا ينبغي أن تهمل ، ومن ثم يبدو التركيز على المخاطب ونفسيته التي ينبغي ألا تتفر قبل حصول المقصسود دون أن يشـعر بـه ، والتركيز على المـتكلم ومـدى براعتهـ في الاحتيال من أجل تحصيل هذا الغرض ، وهو مـا يبدو واضحا في تعريف ضياء الدين ابن الأثير الاستدراج بأنـه : " مخادعات الأقوال التي تقوم

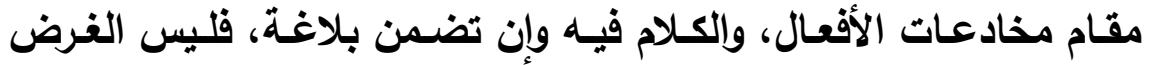
ههنا ذكر بلاغته فقط، بل الغرض ذكر مـا تضمنه من النكت الدقيقة في استدراج الخصم إلى الإذعان والتسليم، وإذا حقق النظر فيه علم أن مدار البلاغـة كلها عليه؛ لأنـه انتفاع بإيراد الألفاظ المليحة الرائقة، والمعاني اللطيفة الدقيقة دون أن تكون مستجلبة لبلوغ غرض المخاطب بها...فإذاذ لم يتصرف الكاتب في استدراج الخصم إلى إلقاء يده، وإلا فليس بكاتب،

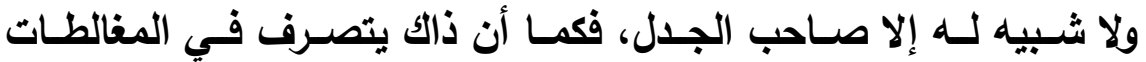
القياسية، فكذلك هذا يتصرف في المغالطات الخطابية. (2)

(1) إرشاد العقل السليم إلى مزايا القرآن الكريم، أبي السعود محمد بن محمد العمادي ـ دار إحياء التراث العربي - بيروت - 3 / 297 .

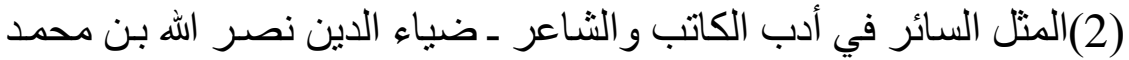
الثيباني، أبو الفتح ، المعروف بـابن الأثير الكاتب (ت 637هـ) ـ تحقيق

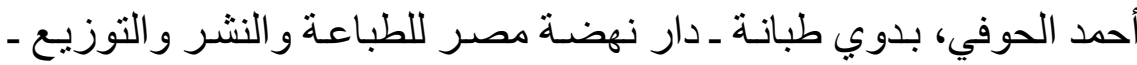


وقد أجاد حين حدده في مؤلف آخر بأنـه : التوصل إلى وصول الغرض من المخاطب، وإلملاطفة له بلوغ المعنى المقصود، من حيث لا يشعر بـه، وفي ذلـك مـن الغرائب، واللدقائق مـا يوثق السـامع، ويطربـه؛ لأن مبنى صناعة التأليف عليه، ومنشأها منه. (1) صنئ

ومثله قول نجم الدين ابن الأثير : " يقال : استدرج فلان فلانـا إذا توصل إلى حصـول مقصسوده مـن غير أن يشعره مـن أول وهلـة ، والمـراد بـلتك الملاطفة في الخطاب ، ولزوم الأدب في الكلام مع المخاطب بحيث لا تثفر

نفسه قبل حصول المقصود منه " (2)

وقول التتوخي : " ومـن البيان الاستـدراج ، وهو استمالة المخاطب بمـا يؤثره ويأنس إليهه ، أو بمـا يخوفهه ويرغبه قبل أن يفاجئه المخاطب بمـا يطلب منهه ، وهذا باب واسـع ، وهو أن يقدم المخاطب مـا يعلم أنـه يؤثثر في نفس المخاطب من ترغيب وترهيب وإطماع وتزهيد ، وأمزجة الناس تختلف في ذلك ، فينبغي أن يستمال كل شـص بمـا يناسبه ، وهذا لا يؤثر فيه التعليم إلا يسيرا " (3) وقول العلوي : إن الاستدراج " هو مـا يكون موضوعا لتقريب المخاطب (1) الجامع الكبير في صناعة المنظوم من الكلام و المنثور ـ ضياء الدين

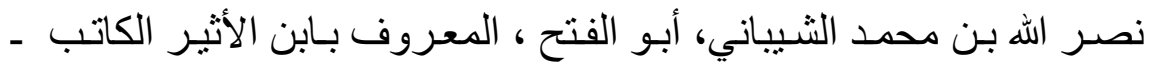

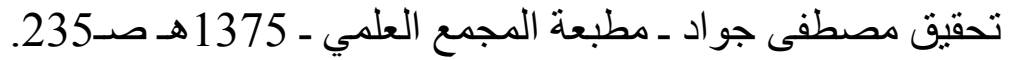

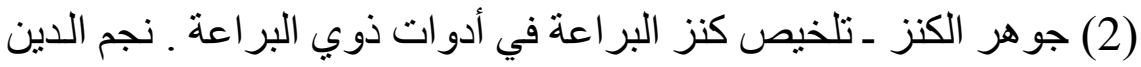

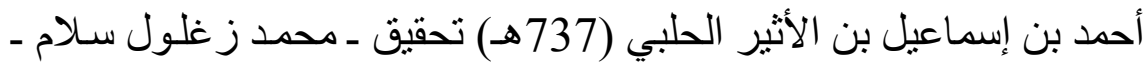

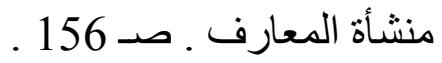
(3) الأقصى القريب في علم البيان للتنوخي ـ السـعادة ـ الأولى 1986 صـ 
والتلطف به والاحتيال عليه بالإذعان إلى المقصود منـه ، ومسـاعدته لـه بـالقول الرقيق والعبـارة الرشـيقة كمـا يحتـال على خصـمه عند الجـدال والمنـاظرة بـأنواع الإلزامـات ، والانتمـاء إليـهـ بفتـون الإفحامـات ، ليكون مسرعا إلى قبول المسألة والعمل عليها ، وكمن يتلطف في اقتناص الصيا ، فإنه يعمل في الحبالة كل حيلة ، ليكون ذلك سبيلا إلى ما يقصده من

(1) "الاصطياد " (1)

والإثــارات البلاغيـة فـي مثـل (دون أن تكـون مسـتجلبة لبــوغ غـرض المخاطب بها) ، و (إذا توصل إلى حصول مقصوده من غير أن يشعره من أول وهلة) ، و(استمالة المخاطب بما يؤثثره ويأنس إليه) ، و(ما يكون موضـوعا لتقريب المخاطب والتلطف بـه والاحتيـال عليـه بالإذعـان إلى ملى المقصود منـه) كل هذه إثـارات بلاغيـة جيدة ، تصب في بـاب استمالة المخاطب والاحتيال عليه في لطف ، غير أن الإثـارة البيانية إلى تثبيه المستدرج بالصائد الذي يحتال من أجل تحصيل الصيد ـ في قول العلوي . تبدو إثارة في غاية الجودة ، ذلك أنها تثير إلى فلسفة القصد التي تحيل فعل المستدرج إلى لبنة فاعلة من لبنات البناء القني في القصيدة ، حتى القى لا يظن أن هذا الصنيع كان مجرد مصادفة ، ولـم يكن منهجا من منـاهج البناء القني في القصيدة العربية . أمـا عن وقوع تقتيـة (2) الاستـارج في القصيدة العربيـة القديمـة فتبـدو (1) الطر از - يحيى بن حمزة بن علي بن إبر اهيم، الحسيني العلويّ الطالبي

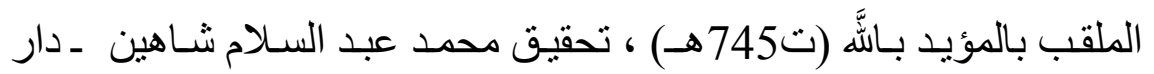
الكتب العلمية ، الأولي 1995 صـ337 بلد (2) التقنية :" جملة المبادئ أو الوسائل التي تعين علي إنجاز شئ أو تحقيق

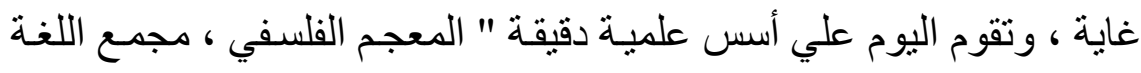


ملامحه النقدية واضحة في قول ابن رشيق في فلسفة مقدمة القصيدة : " وللشعراء مذاهب في افتتاح القصائد بالنسيب ؛ لما فيه من عطف القلوب ، واستداءع القبول بحسب مـا في الطباع من حب الغزل ، والميل إلى اللهو والنساء ، وإن ذلك استدراج إلى ما بعده " (1) . فـلا يخفى أن التعبير بالمـذهب في قول ابـن رشيق يؤكد تـوفر جانب القصد من الثـاعر الذي يستـرج القارئ أو المستمع حتى يضمن ولاءه وإنصاته لكل ما يقول . أما في العصر الحديث فتبدو ملامح الاستدراج القني في القصيدة في قول الشـاعر أحمد عبد المعطي حجازي : " وهنـاك اعتبار فني يدفع الشـاعر إلي تقديم العاطفة الثانويـة وتأخير العاطفة الجوهريـة ، هذا الاعتبـار هو التأتي لغايته وتمويهها علينا ، واستدراجنا إلي انفعال أول يثيره فينا ، فلا نكاد نتدمج فيه حتى يخرجنا الشاعر منه بضرية من ضريات العبقرية إلـي انفعال آخر يفاجئنا به علي غير توقع بعد أن يمهر له بنقيضه الأي يؤكد

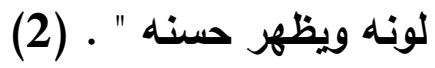
كما تبدو ملامـح الاستثراج في هذه التقتية القتية التي سـماها الدكتور محمد العزب بالخداع الفنـي ، والتي يرى فيها " تحريض المتلقي علي

العربية 1979 صـ 53 ـ ويمكن استخدام كلمة التقنية ـ المعربة حديثا - بدلا

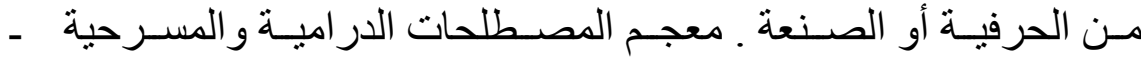

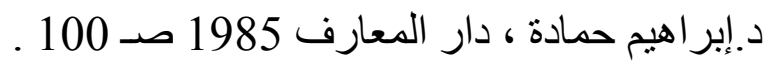

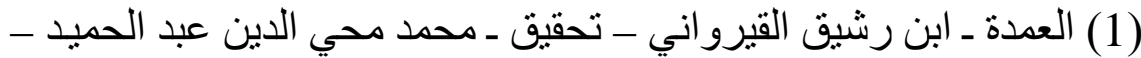

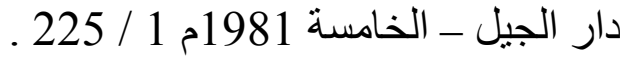

(2) في مملكة الثعر ـ أحمد عبد المعطي حجازي ـ الهيئة المصرية العامـة للكتاب 1999 صـ 23 . 
رفض المستوي الأول للنص ، طموحا إلي الوصول للمستوي الثاني والضد في آن ... ويما أنه تظاهر القنان بالبراءة أو السبح في اتجاه آخر ، أو الو المباشـرة ، أو اتهـام الـذات ، بينمـا هـو يغوص حتى حافـة التقلسفـ ، ويسبح حتى عمق الاتجاه النقيض ، ويوري ويكني ويستعير حتى أقصسي حـود المجـاز ، ويـتهم الآخـرين حتـى أعلــي قـــة فـي إعـلان بــراءة

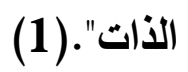

ففي قول ابن رشيق وقول الاكتور ـ محمد العزب ـ تركيز على ذلك النوع من الاستدراج الأي يعنى بتتبع الإثارة المنبعثة من بناء القصيدة ذاته ،

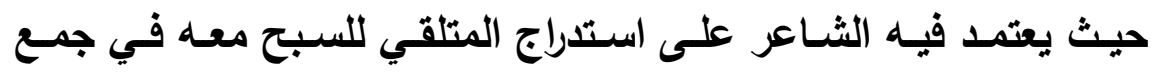
تتويعاته الغتائية التي يكدسها في القصيدة ، رغبة منـه في الوصول إلى نهاية لا يحس فيها المتلقي بطول الرحلة ، أو عناء الريط بين أجزائها ، أو يعتمد فيه على خداع المتلقي وتحريضه على رفض المستوى السطحي للنص ، طموحا إلى الوصول للمستوى الثاني المغاير أو الضد في آن ، لأن البعد الآخر للنص هو غاية الثاعر الأولى ، أما البعد الأول المسطح فهو مجرد تمويـه أو خداع للمتلقي مـن أجل التورط في الفعل القرائي والتفكيري ، وهذا القصد البنائي المراوغ يمكن أن نقف مثثلا على ملامحه في القصيدة العربيـة مـن خـلال وقوفنـا مثثلا على جوهر (المقدمـة) في

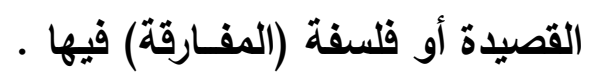
وفي قول حجـازي تركيز على ذلـك الاسـتدراج الذي ينـي فيـه الشـاعر

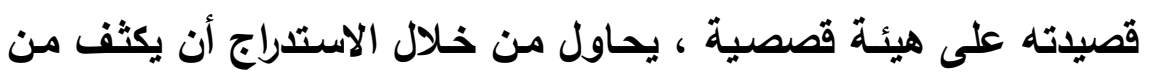

(1) في النص الثـعري الحديث ـ ـ / محمد أحمد العزب ـ الطبعة الأولي 2000 
دراميتها ، أو أن يمــ المتلقي بوجبات أخرى مسن القص لـم يستطع أن يسعفه بها ، أو أن يتعمد الثاعر صدم قارئه لإثارة جاتب الحدس عنده ، وليجعله في حالـة ترقب مسـتمر ، مسن خـلال تقديم العاطفـة الثانويـة ، وتأخير العاطفـة الجوهريـة ، وهو مـا يبدو واضـحا في أسـلويـي (النهاية المفاجئة) و (الارتداد) القصصي ، بما تحدثه هاتـان التقتيتان من تداخل النوع الأدبي في القصة وإلشعر • وجدير بالأكر أن كل هذه الإشـارات النقديـة قديما وحديثا إنما كاتـ تهتم برصد أسس الاستدراج الذي يخص بنية القصيدة الغنائية ، أمسا حرفيات الاستدراج القصصسي فلم تكن بحاجـة إلى مثل هذه الإثـارات ؛ ذلتك أن القص كـان يستعين في أداء رسـالته بوسـائل عدة ، ويستـرج القاريء بوعي أو بـدون وعي ، حتى تصل إليسه رسـالته ، ومـا مـن شـك في أن القصيدة العربية ويخاصـة في العصر الحديث قد استطاعت أن تفيد من إمكانـات القصـة والمسرحية ، ممـا عـاد على القصيدة بـألوان جيدة مسن الاراميـة ، تعـددت فيهـا الأصسوات والأحساث ، وتـداخلت فيهـا كثيـر مسن الأنواع الأدبية ، وقد أقلح الثاعر الحديث في استدراج المتلقي إلى الإقرار بأفكار وقتاعـات مختلفة ، عن طريت الاستئناس بأسس الأنـواع الأدبية الأخرى ، التي أسهمت في اقتحام خلوته ، وتأكيا مشروعية مـا يلقى إليه ، وهو ما يمكن لصفحات البحث أن تبرهن عليه بكل وضوح . 


$$
\text { بـ عبدالميدمحد بلران }
$$

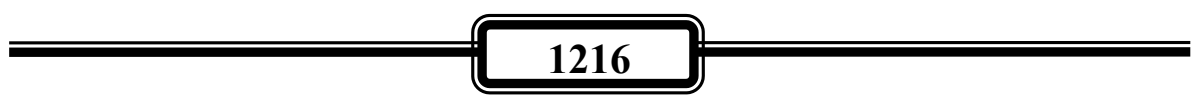


نظن أن مقدمة القصيدة العربية التي ظلت مرتبطة بها حينا من الدهر ـ لم تكن في كثير منها إلا لونا من ألوان استدراج المخاطب/الممدوح والاحتيال

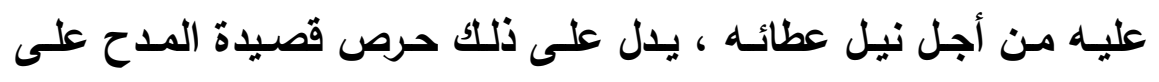
اصطحاب هذه المقدمة المكلسة بالمراحل والموضوعات ، على النحو الأي يجسده قول ابن قتيبة : " قال أبو محمد : وسمعت بعض أهل الأدب يذكر أن مقصِّ القصيد إنما ابتدأ فيها بذكر الديار والدمن والآثار ، فبكى وشكا

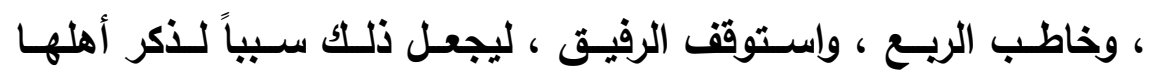
الظاعنين عنها ، إذ كان نازلة العمد في الحلول والظغن على خلاف مـا

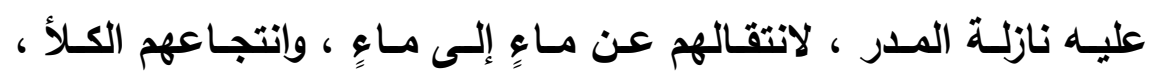
وتتبعهم مساقط الغيث حيث كان ، ثم وصل ذلك بالنسيب ، فشكا شدة الوجد وألم الفرلق وفرط الصبابة والثوق ، ليميل نحوه القلوب ، ويصرف إليه الوجوه ، وليسترعي به إصغاء الأسماع إليه ، لأن التشبيب قريبّ من

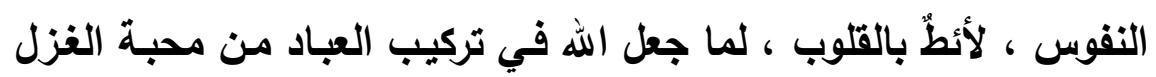

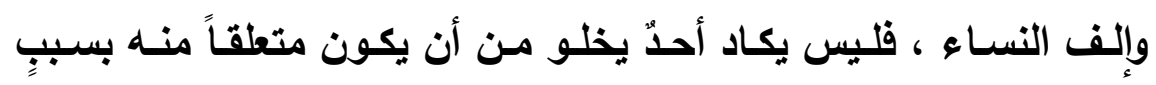
وضارباً فيه بسهِ ، حلالٍ أو حراٍٍ ، فإذا علم أنه قد استوثق من الإصغاء إليـه ، والاستماع لـه ، عقب بإيجاب الحقوق ، فرحل في شـعره ، وشكا النصب والسهر وسرى الليل وحل الهجيز ، وإنضاء الراحلة والبعير ، فإذا لهاب علم أنه قد أوجب على صاحبه حق الرجاء وذمامة التأميل وقرر عنده مـا ناله من المكاره في المسير ، بدأ في المديح ، فبعثه على المكأفاة ، وهزه للسماح وفضله على الأشباه ، وصغز في قدره الجزيل ، فالشـاعر المجيد من سـلك هـذه الأسـاليب ، وعدل بين هـذه الأقسـام ، فلم يجعـل واحــاً 
منها أغلب على الشعر ، ولم يطل فيمل السامعين ، ولم يقطـع ويـالنقوس

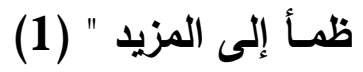

وكلام ابن قتيبة السابث يضعنا وجها لوجه أمام فلسفة البناء في المدحة الجاهلية ، وأسباب احتوائها على عديا من الموضوعات ، كمـا أنها يعطينا تصورا لطغيان جانب الصنعة على الثـاعر الذي يحاول جاهدا أن يطوع آلته الشعرية من أجل الدخول في بكاء الديار بعد الوقوف على أطلال أهلها الظاعنين ، ثم التخلص إلى ذكر النسيب ، ليعرف بصساحبة الديار ، ويستميل إليه الأسماع .. الـخ ، وهو مـا سـماه ابن رشتق القيروانـي بعد

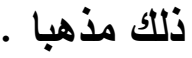
غير أن ابن رشيق قد صرح بـأن هذه المقدمات استـراج مـن الشـاعر للولوج فيمـا بعدها من الموضـوعات في قولـهـ : " وللشـعراء مـذاهب في افتتاح القصائد بالنسيب ؛ لما فيه من عطف القلوب ، واستثدعاء القبول بحسب مـا في الطباع من حب الغزل ، والميل إلى اللهو والنسـاء ، وإن ذلك استدراج إلى ما بعده ، ومقاصد الناس تختلف : فطريق أهل البادية ذكر الرحيل والانتقال وتوقع البين والإثفاق منه ، وصفة الطلول والحمـل ، والتشـوق بحنين الإبـل ولمـع البروق ومـر النسيم ، وذكر الميـاه التي لمي يلتقون عليها ، والريـاض التي يحلون بها ، من خزامس وأقحوان ويهار وحنوة وظيـان وعرار، ومـا أشبهـها من زهر البريـة الذي تعرفـه العرب ، وتتبته الصحاري والجبال ، وما يلوح لهم من النيران في الناحية التي بها أحبـابهم ، ولا يعـدون النسـاء إذا تغزلـوا ونسـبوا ، فـإذا وقـع مثـل قـول

(1) الثعر و الشعر اء لابن قتيبة ـ تحقيق/ أحمد شـاكر - دا المعـارف 1982 $.76-74 / 1$ م 
طرفة:)

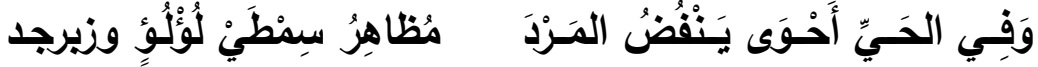
فإنما هو كناية بالغزل عن المرأة ، وأهل الحاضرة يأتي أكثر تغزلهم في ذكر الصدود والهجران والواثشين والرقباء ، ومنعة الحرس والأبواب ، وفي باني ذكر الشـراب والندامى والكورد والنسرين والنيلـوفر ، ومـا شـاكل ذلكت مـن النواوير البلاية ، والرياحين البستانية ، وفي تثببيه التفاح والتحية به ، ودس الكتب ، وما شاكل ذلك مما هم به منفردون ." (2)

(1) البيت لطرفة في ديو انه. شرح دهدي محمد ناصر الدين ـ دار الكتب الكبر

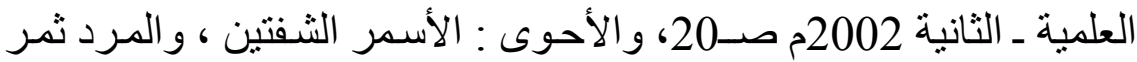

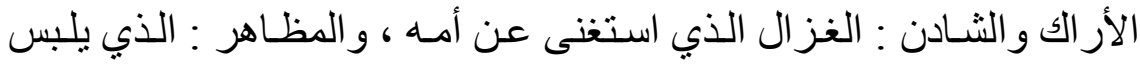
عقدا فوق عقد ، و السمط : الخيط الذي تنتظم فيه الجواهر الهر . يقول: وفي الحي حبيب يشبه ظبيًا أحوى في كحل العينين وسمرة الثففتين

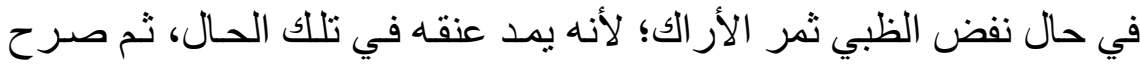

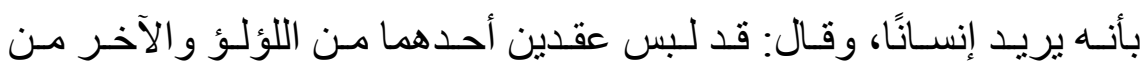

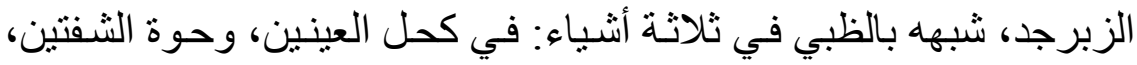

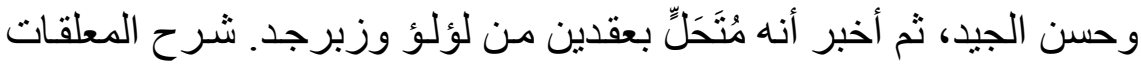

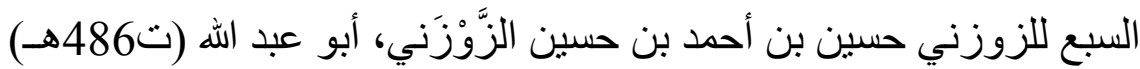

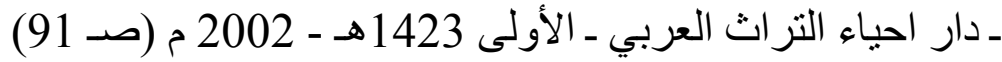

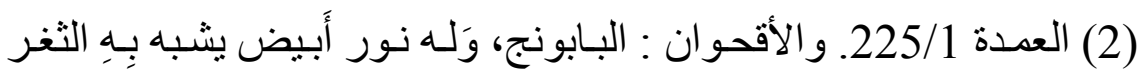

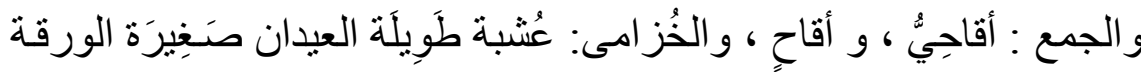

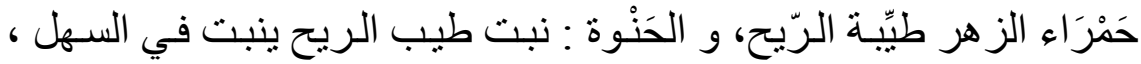

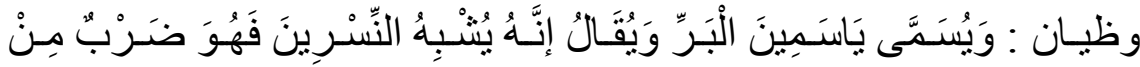

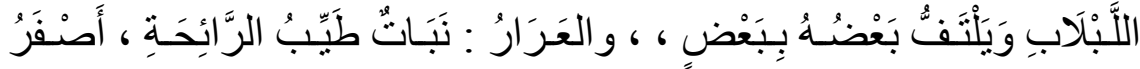

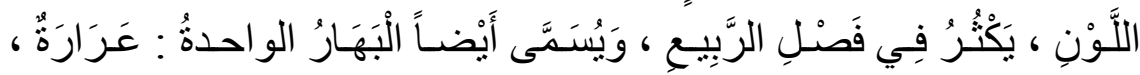




\section{أساليب الاستـــراج في القصيـــة العربيــة}

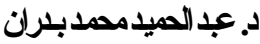

وقول ابن رشيق بأن (ذلك استدرج إلى مـا بعده) قريب من تعبير العلوي بالاحتيال (1) ، وتعبير الإمام الطبري بالاغترار (2) ، وهو يدل على أن " نوعية المطلع أحيانا تخدع النظرة العابرة إليه ، فقد يكون المطلع غزلا في ظاهره ، وهو بهذا الظاهر يخدع غير المتأمل ، فيظن أن الشـاعر يقصد الغزل حقيقة أو تخيلا ، مـع أنتا نلحظ أن الشاعر حينئذ إنما يجعل من هذا الغزل رمزا إلى نفسيته ومشاعره نحو موضوع القصيدة ، أو الموقف الأي قال فيه القصيدة ، وقد رأينا كيف أن النابغة الذبياني جعل مطلعه المشهور غزلا في الظاهر ، ولكنه في الحقيقة ليس غزلا ، وإنما هو تعبير

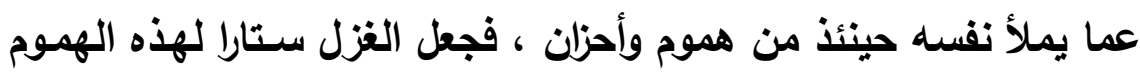
، ولكنـهـه سـتار شـفاف لا يخفـي مــا وراءه " (3) ، وإلا فمـا الــي جعـل (4) الثاعر يطلب من حبيتهل أن تتركه وهمومه التي تحاصره ؟ في قوله

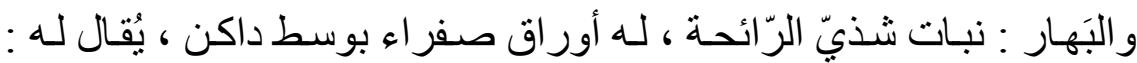

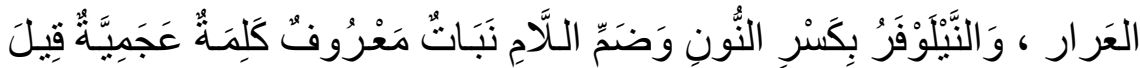

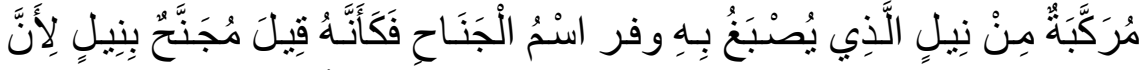

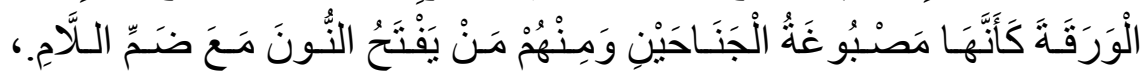

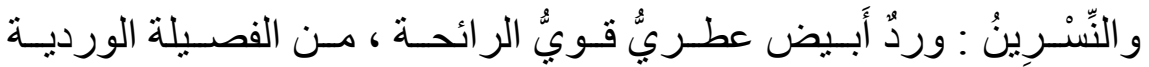

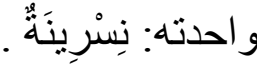

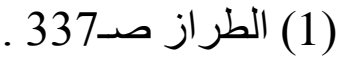
. 135 / 135 ـ (1)

(3)مطلع القصيدة العربيـة ودلالتهـ النفسية د ـ ـ عبد الحليم حفنـي ـ الهيئة

$$
\text { المصرية العامة للكتاب 1987م صد } 70
$$

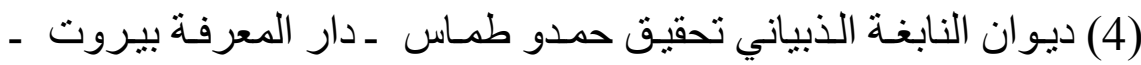
الثانية 2005 صـ 13 ـ 
إصدار 2017

يَ

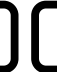

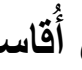

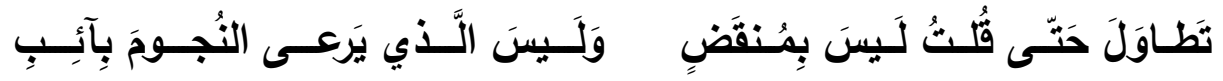

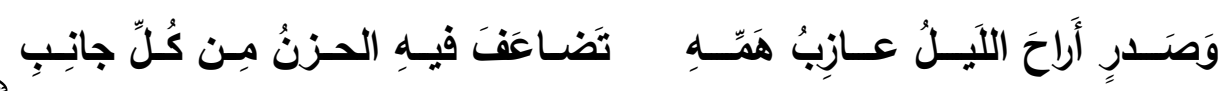

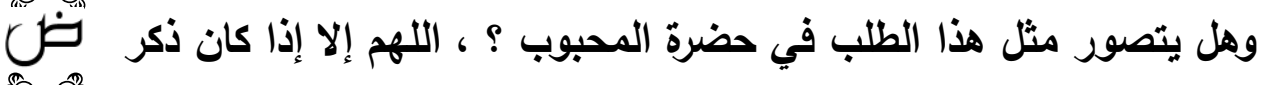

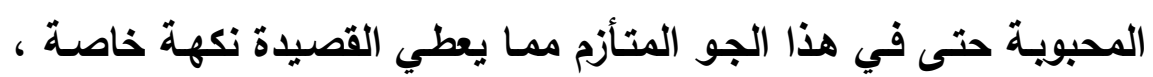
وحلية قصصية تعكس نفسية الثـاعر الحزينة حتى في لحظات أنسها بحبيبها . ونتيجة تعدد الموضوعات في القصيدة كلف العرب بالطرب إلى حسن التخلص (1)، عندما يأتي مدهشا من غير حدس ومن ذلك وقوف ابن ابن

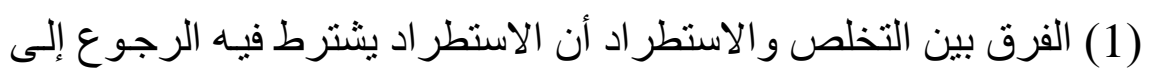

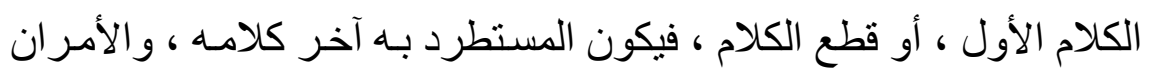

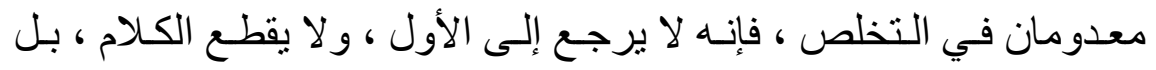

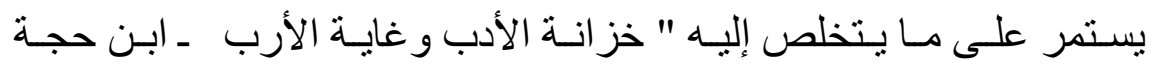

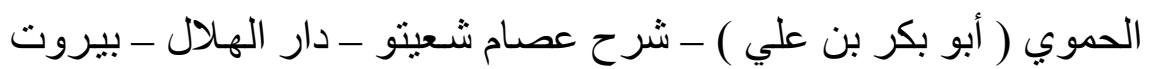

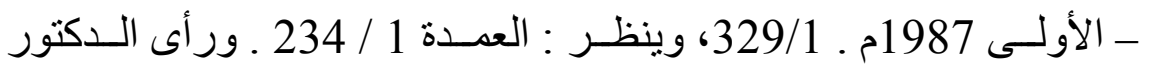

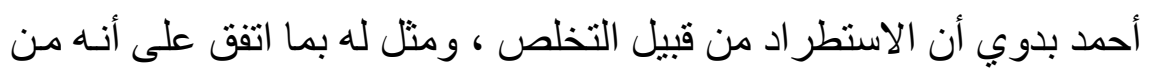
حسن التخلص و هو قول حسان بن ثابت :

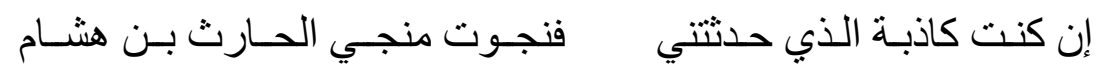

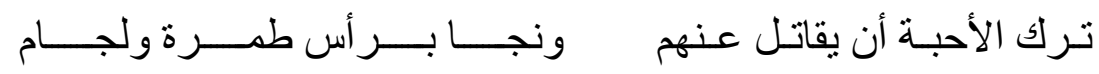
ولعل الذي دفعه إلى ذلك وجود التقارب بين اللونين عند قطع الكلام في

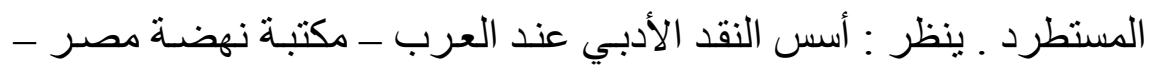

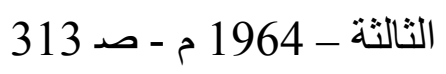


الأثير على قول إسحاق بن إبراهيم الموصلي:

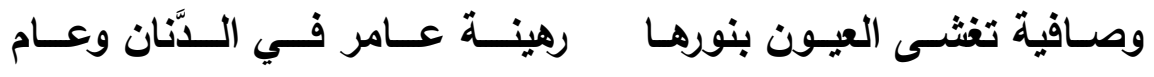

أَدَرنـا بهـا الكـأس الرويسة بينــا مـن الليـل حتـى اتجـاب كـل ظـلام

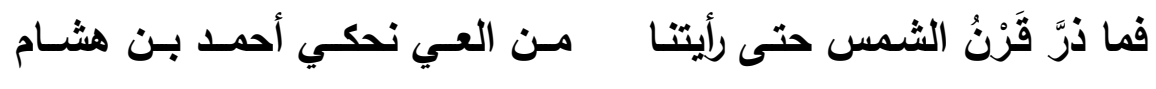
ثم قوله " ألا ترى ما أحسن مـا خرج هذا الشـاعر في الهجاء، فإنـه أوهم في الأول الخوض في صفة الخمر ثم استدرج المعنى الذي قصده في صفة الخمر، من حيث لا يعلم السامع لمطلع كلامه أنه يريد ذلك . (1) وقد بلغ هذا القول من الطرافة وحسن الحيلة مـا جعل الثعالبي يعنون لـه تحت عنوان (طريق القافية) حيث ذكر هناك أن أَحْمد بن هِشَّام قال لـه :

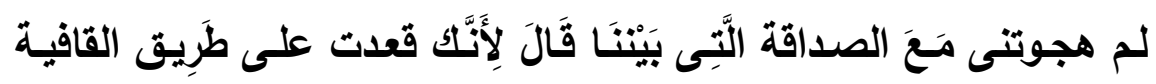

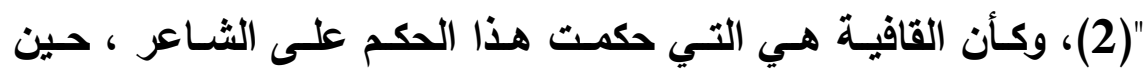

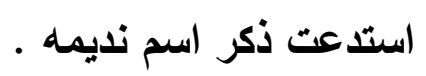
أما الاستدراج القني الذي يبدو متحققا بصورة جيدة في مقدمة القصيدة فيمكن الوقوف عليه في اعتذاريـة كعب بن زهير التي أنشدها رسول الله

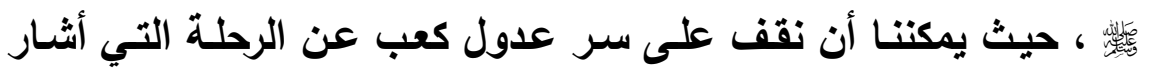
إليها ابن قتيبة ، إلى النسيب الذي أثنار إلبـه ابن رشيق ، لأن مذهب

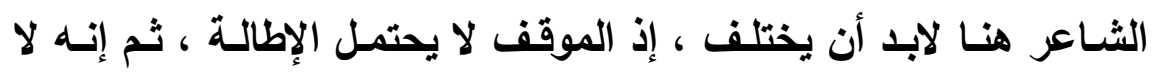

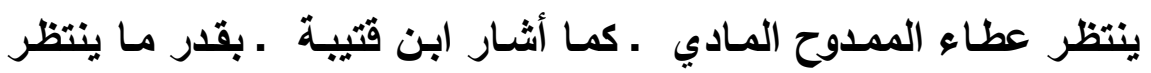

(1)(الجامع الكبير في صناعة المنظوم من الكلام والمنثور صـ 186. (2)ثمار القلوب في المضاف و المنسوب ـ عبد الملك بن محمد بن إسماعيل أبو منصور الثعالبي (ت 429هـ) ـ دار المعارف ـ القاهرة صـ 659. 
العطاء المعنوي متمثلا في العفو والصفح ، لأن غرض القصيدة الأسـاس

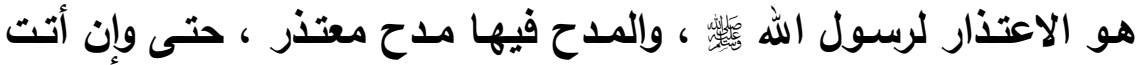
القصيدة في مجملها معبرة عن الرحلة ، على ما يبدو من قول كعب :

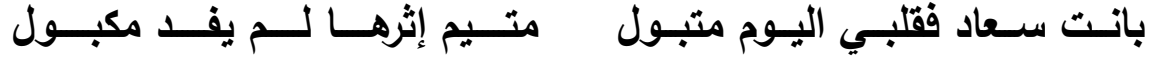
ومـا سـعاد غـداة البـين إذ رحلـوا إلا أغن غضيض الطرف مكحول حيث يحسن الثاعر التخلص - بعد أبيات - إلى وصف الناقة التي سوف تبلغه مراده للقاء هذه الحبيبة فيقول : (1)

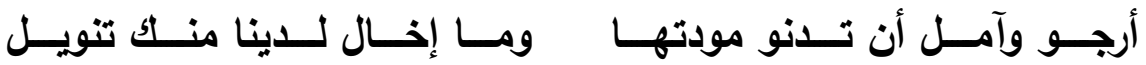
أمســت ســاد بـأرض لا يبلغهــا إلا العتــاق النجيبــات المراســيل

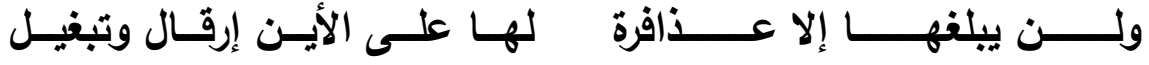
ثم يخلص الثاعر- بعد أبيات - إلى الاعتذار من خلال درامية أبطالها هو والغواة الذين ينذرونه بالقتل ، وأصدقاؤه الأي شغلوا عنه ، وهو مصرٌ الحرّ على ملاقاة مصيره المحتوم ، على ما يبدو من قوله : (2)

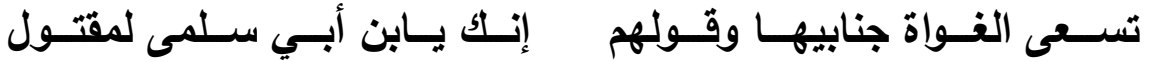

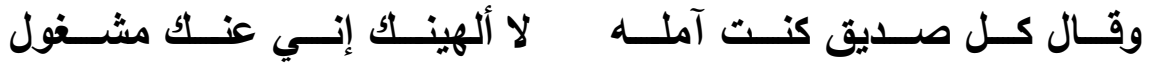

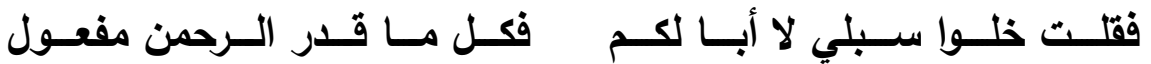
(1) العذافرة : الناقة الثـديدة ، و الارقـال : ضَربٌّ من العَدْوِ، فَوقَ الخَبَب، و التبغيل : تفعيل من البغل شبه سير الناقة بسير البغل لثدته

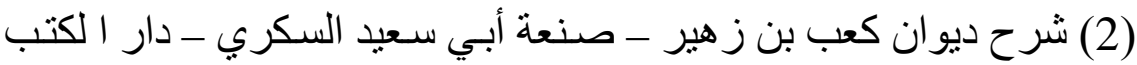

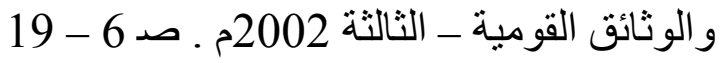




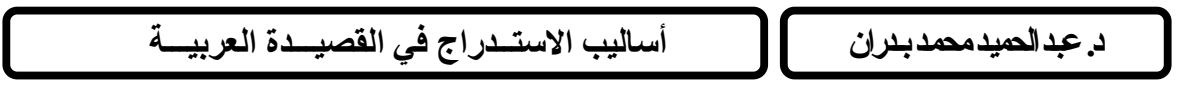
كل ابـن أنثى وإن طالت سـلامته يومـا على آلـة حـباء محمـول

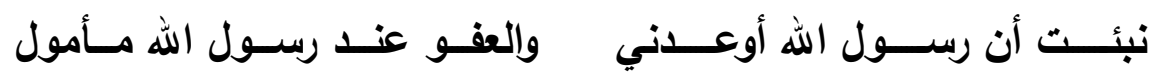
والقصيدة بهذه الصورة على قدر من الترابط لا يسمح بتقديم أي جزء من أجزائها على غيره ، وقد حمل حسن التخلص على عاتقـه عبء توفير

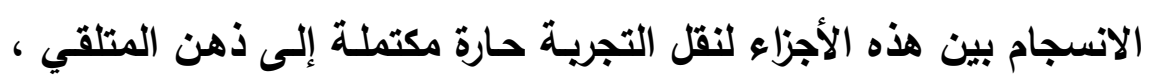
ومن ثم وجدنا الثـاعر يوظف التراث في جلب أدلة مادية على أن هذه المرأة ليست عاديـة ، فهي مـاكرة متلونـة تلون الغول (1) ، وهي خائنة للعهد مخلفة للوعد مثل عرقوب (2) ، ورغم كل هذه الأوصاف المستنكرة

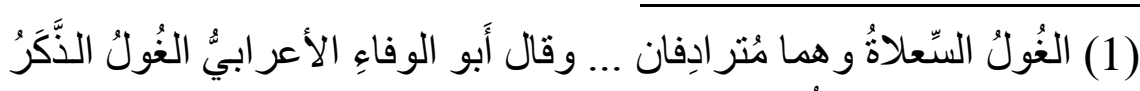

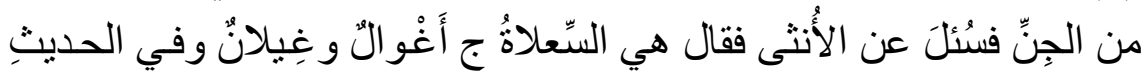

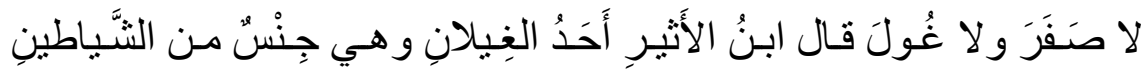

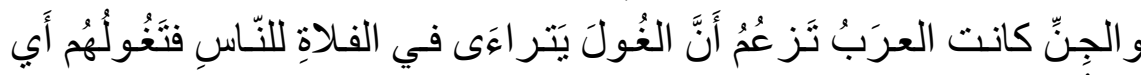

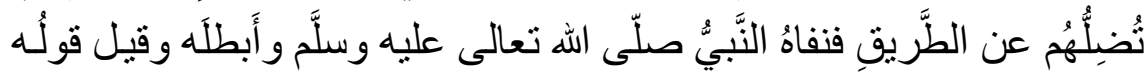

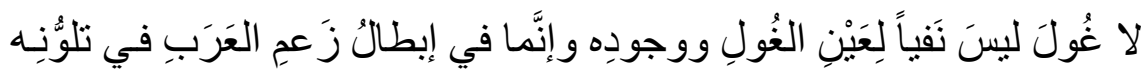

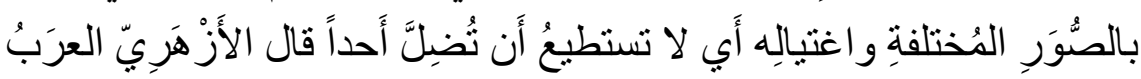

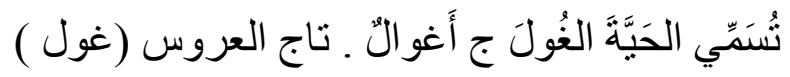

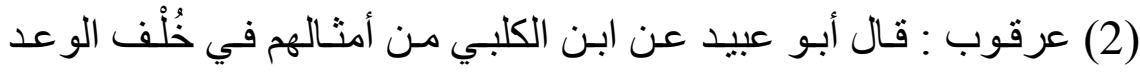

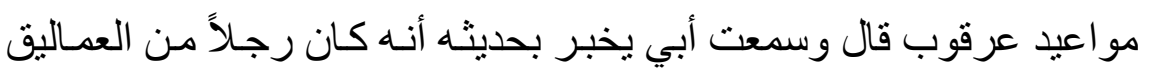

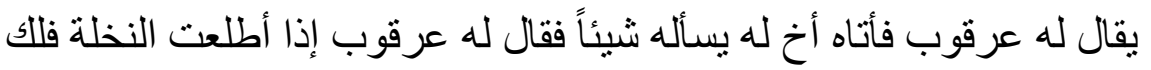

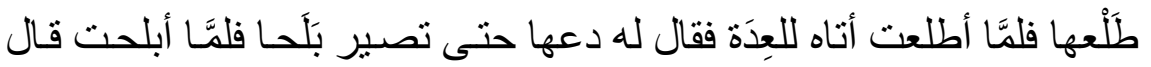

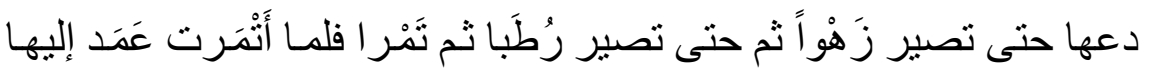

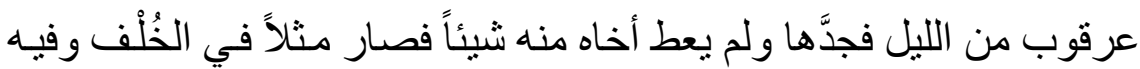

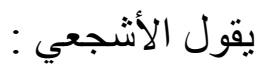


يرجو الشاعر أن تدنو مودتها ، ويصمم على السفر إليها رغم المشقة ، لماذا ؟ ... لا ندري ، وأين نعثر على الوصول إليها في القصيدة بعد هذه

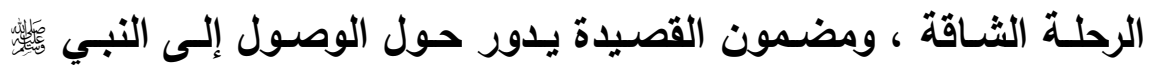
والاعثذار لله في المدينة ؟ لا نعلم أيضا . هذه إثكالية ينبغي أن نضعها في الاعتبار ، حتى نصل إلى الاقتناع بأن لترلّ هذه الحبيبة الخادعة ليست امرأة حقيقية كما تصورنا في البداية ، وإنما هي معادل طبيعي لسعادة الشـاعر التي فقدها لمـا علم بإهدار التبي لهي دمه ، هذه السعادة التي أخلقت وعدها معه حين لم يقبل نصحاً من أحد ، فبانت عنه وأصبحت بأرض بعيدة هي المدينة حيث الرسول فئس في ، وحيث (1) أصحاب كعب يلتفون حول ناقته في مشهر مأساوي يجسده قوله : تســـى الغــواة جنابيهــا وقـولهم إنــك يـابن أبـي سـلمى لمقتـول

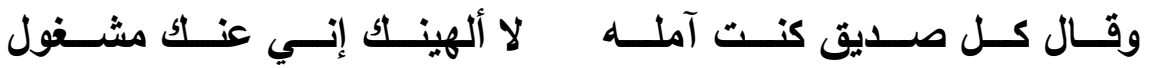
فقلـت خلـوا سـبيلي لا أبـا لكـم فكـل مــا قـدر الـرحمن مفعـول

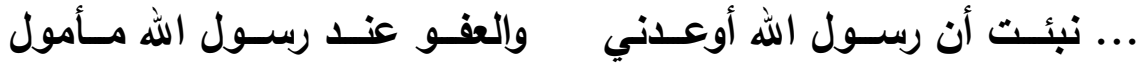

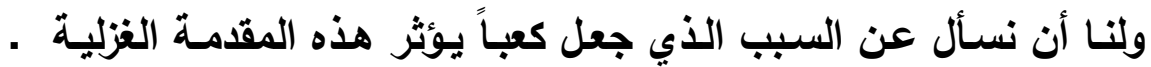
والغزلية بالذات ـ كنموذج رمزي لمـا يريد أن يقولـه لجمهوره الحضور ،

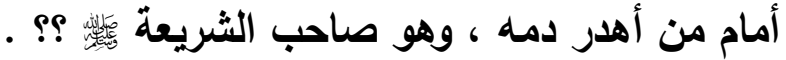
ونظن أن السر في اللجوء إلى هذه المقدمة الغزلية يكمن في أنه يعد لونـاً

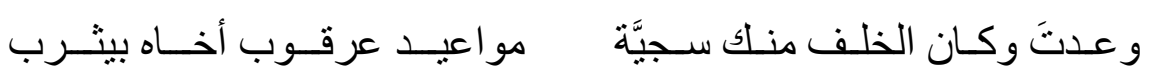

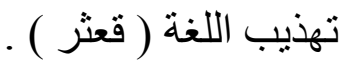
(1) شرح ديو ان كعب بن زهير - صد 19 برواية ( يسعى الوضاة بجنبيها ). 
أساليب الاستــــاج في القصيـــة العربيــة

من ألوان تحسر الثـاعر على مسلماته وأدواته الشعرية التي كان يعتز بها، والتي أحس فجأة أنها توشك أن تنقلت منسه بعد أن أهدر النبـي دمه، ومن ثم فغزل كعب أو نسيبه ليس كأي نسيب ، إنسه نسبب موظف لغايـة بعينها ، أو رامز إلى شيء بعينه ، لأن الثـاعر يعلم أن التشبيب قريب من النفوس لائط بـالقلوب ، والحبيبة هـي أحب شيء إلى نفس الحبيب وكأنها هي نفسـه ، فأحب الشـاعر أن يثـاكل بينها ويبين نفسـه كلون من ألوان الخداع القني الأي يستعين بـه في تأكيد مراده ، ويحاول من خلاله أن يسلي نفسه ، ويخفف عنها وطأة المجهول الأي يترقبه كل لحظة ، وهذا يؤكد لنا في النهايـة أن الشـاعر كان يودع نفسـه في مطلع القصيدة ، مهما حاول إخفاء ذللك في أغراض لا تمت إلى الوداع بصلة . وقريبب من صنيع كعب بن زهير مـا فعله محمـود سـامي البارودي في إسي العصر الحديث ، حيث تقرأ قصيدته (هجرت ظلوم) فتجده يستهلها بهجر الحبيبة رغم حاجته إليها ، ثم يعلن الثاعر في صراحة أسباب هذا الهجر متمثلة في ظهور الثيب في ناصيته ، ومن ثم تجده يتحسر على الثباب

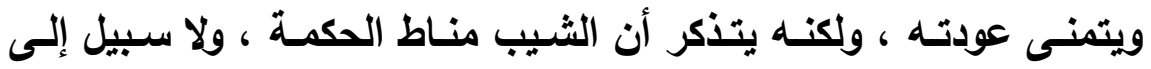
البقاء الأبداي على ظهر الأرض ، ومـن ثم فـلا حاجة للتمني ، غير أن إن الغريب عند البارودي اختياره اسم الحبيبة (ظلوما) ، حيث يقول : (1) هجرت ظلـوم وهجرهـا صلة الأسـى فمتي تجود علي المتيم باللقـا ؟ جزعـت لراعيـة المشـيب ومـا درت أن المشيب لهيب نيران الجـوى (1) ديوان البارودي ـ ضبط علي الجـارم ومحمد شفيق معروف ـ المطبعة

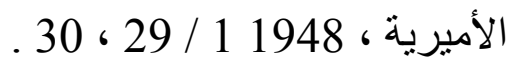


ولـوت بوعـدك بعــ طـول ضــمانه ومسن الوعود خلابـة مـا تقتضـي

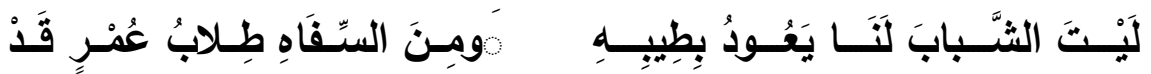

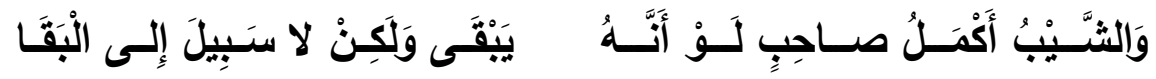

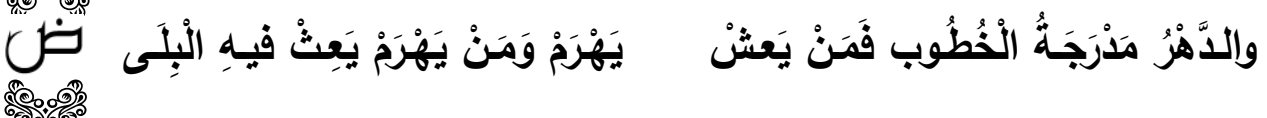

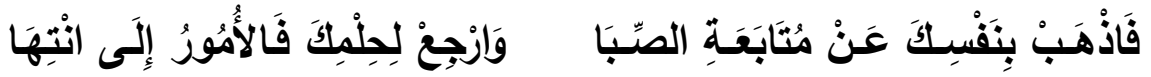

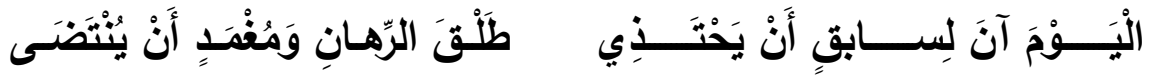
ثم يحـاول الشـاعر تسـلية نفسـه وتصسبيرها ، ومـن ثم لا يجد أمامسه إلا تاريخه المليء بالبطولات ، يتذكره ليفرج عن نفسـه مـا أصسابها من عنت ومشقة ، فتراه يصف جواده وجَلَّه في مواجهة الصعاب في قوله :

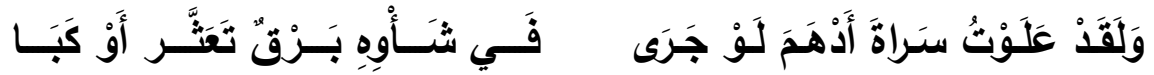

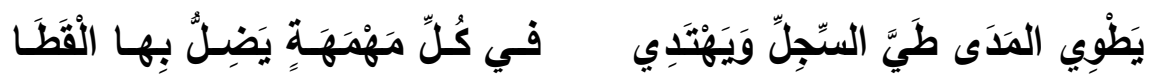

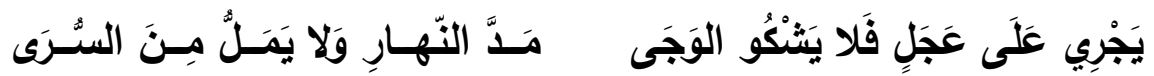

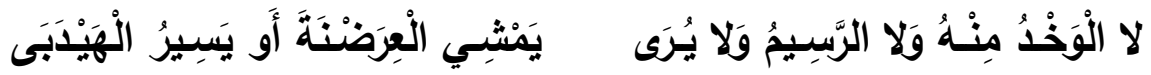

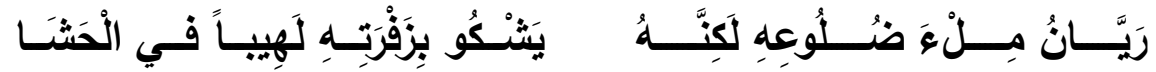

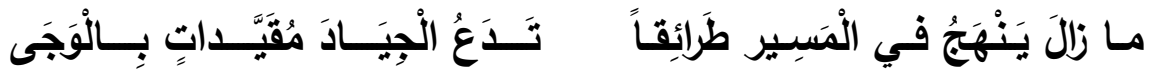
ثم يصل في نهاية الرحلة إلى مكان ساحر يمثل خلاصـة رحلته ، وتتويجا لمشواره الأي ينبغي أن يشكر المولى عز وجل عليه فيقول :

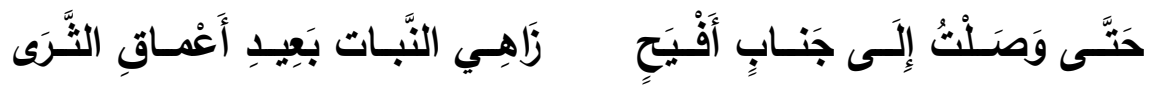




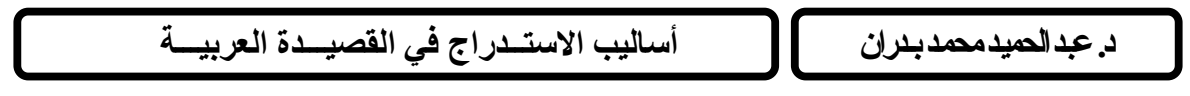

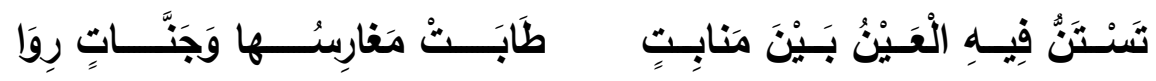

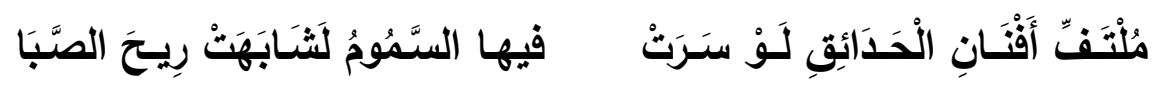

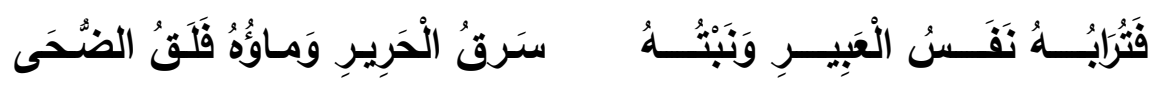

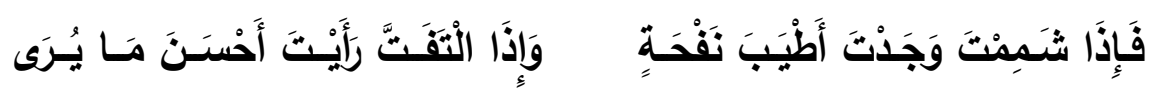

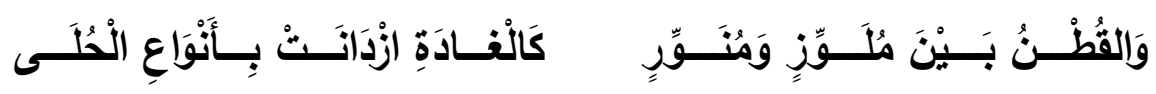

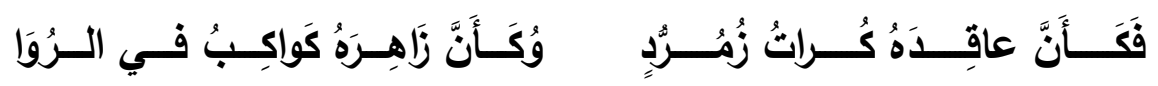

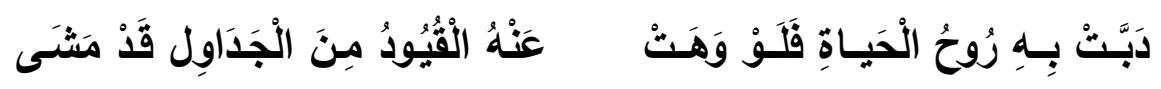

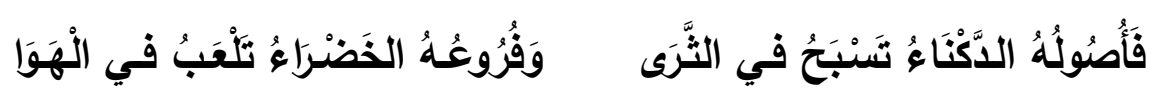

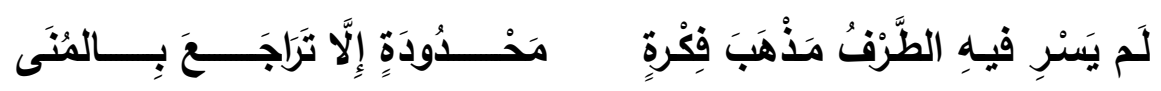

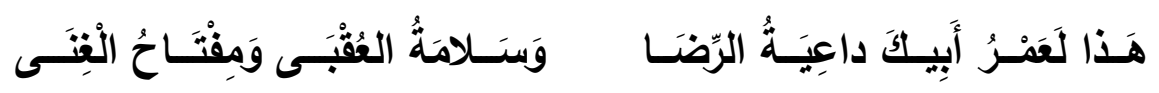
فَعَلامَ أَجْهَدُ فِي الْمَطَالِبِ بـاذِلاً

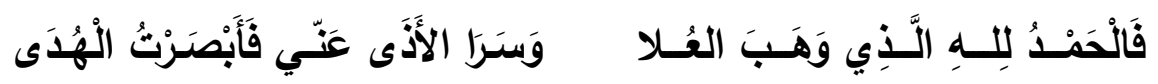
إن الثاعر هنا يرحل على جواده ، ويصف الرحلة مثلمـا وصفها الثـاعر

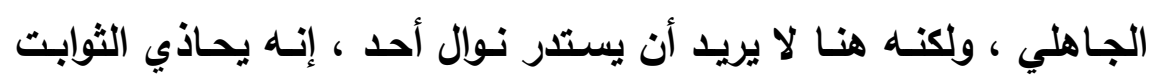
الموروثة ، ويستدرج القاري ع ليطلعه على مدى صبره ورضـاه بما صار

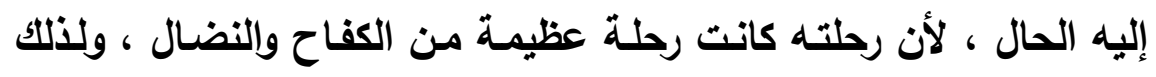
تجد الثاعر ينصرف عن هذه المحبوية إلي الحديث عن فلسفة الشباب والثيب ، بحيث تبدو هذه المحبوية الأنثى ـ بعد ذكرها في المقدمة ـ وهما 
لا وجود لـه ، لأنها المعادل الموضوعي(1) لوظيفته في وزارة الجهاديـة والبحريـة والأوقاف ، التي سـماها بعد الاستقالة منها (ظلومسا) ، لأنها قضت ظلما على رحلته الكفاحية التي اعتاد عليها . ولعل في مقدمات الشعر العربي ما يمكن أن يعطينا ولو تصوراً لتطور هذه الظاهرة الأسلويية ، ويراعة الثـاعر في إحكام صنعته فيها ، فمروان بن أبي حفصة يمدح الخليفة المهدي بقصيدة لا يشك من يقف على مقدمتها أن صـاحبها يهنـئ الخليفـة المهـدي بعروسـه التـي طالمـا داعبـت خيالـه وشـغلت فكره ، حتى ظفر بهـا بعد معـارك غراميـة ، على مـا يبدو مـن

قوله:(2)

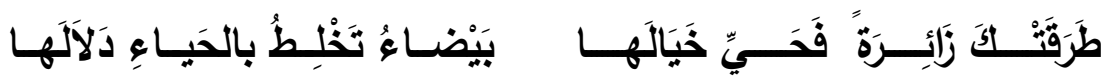

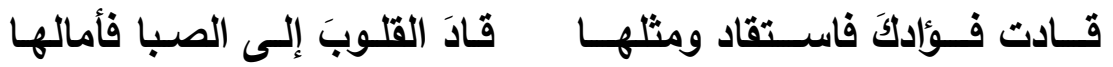

(1) ـ المعادل الموضوعي : سلسلة من أحداث تجعل انفعالا ذاتيا معينـا شيئا

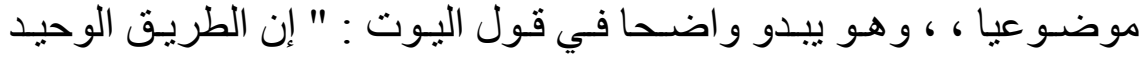

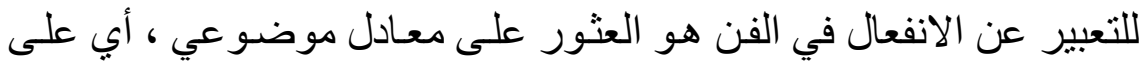
مجمو عة من الاشياء المدركة بالحس ، أو على موقف أو سلسلة من العن الأحداث

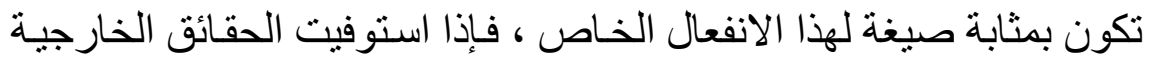

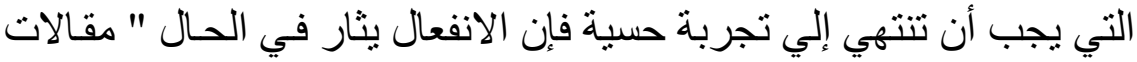

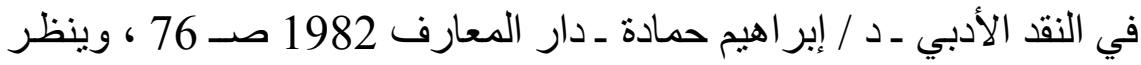

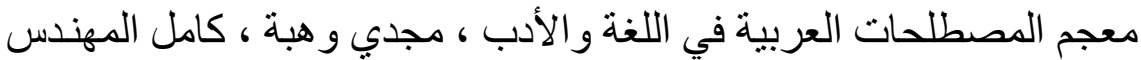

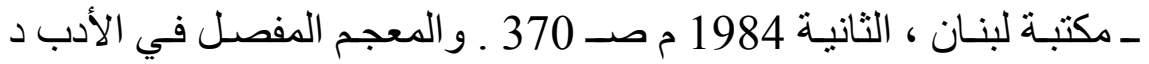

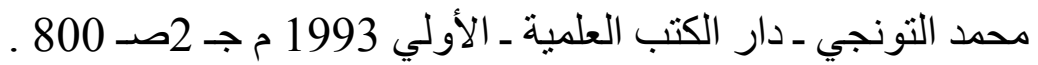

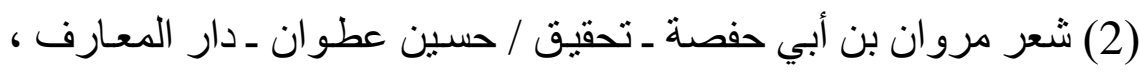
الثالثة 1982 صـ 96 ـ 


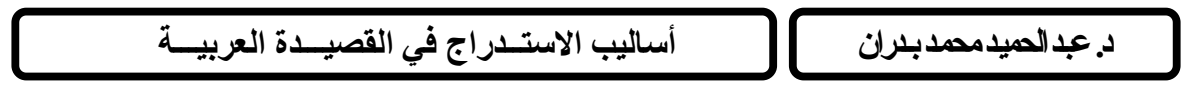

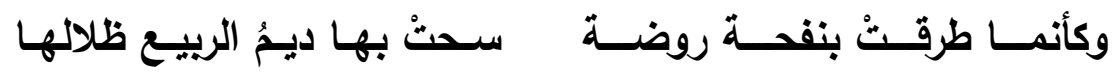

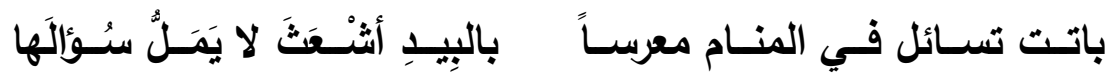

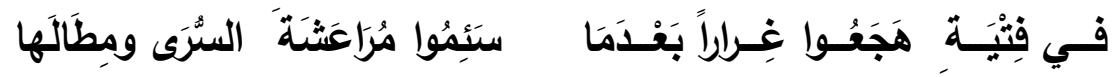

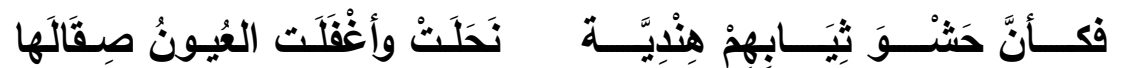

وضعوا الخدود للدى سـواهم جنجِ تشـكو كلـوم صـفاحها وكلالهـا

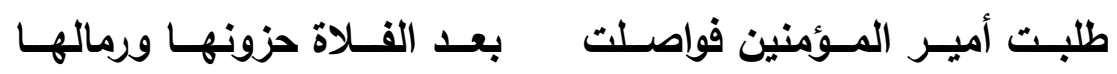

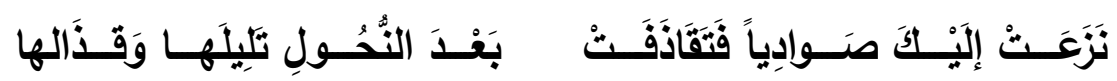

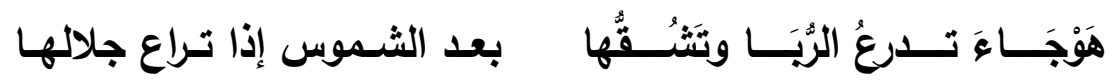

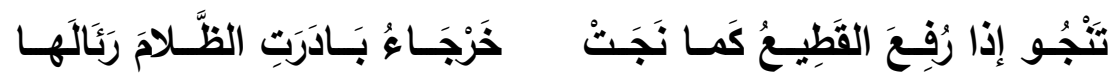

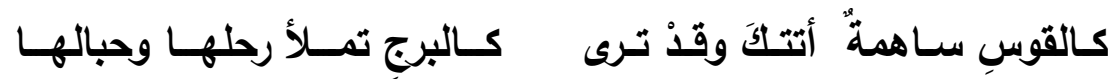

نستطيع إلى هذا الحد أن نتخيل مقدمة طيف الخيال ، وكيف كان يسبح

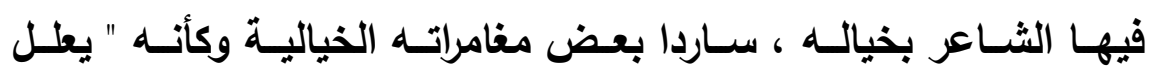

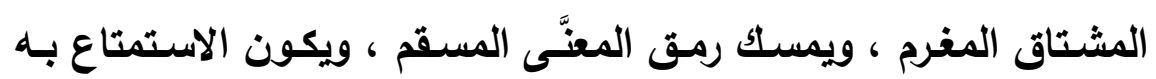

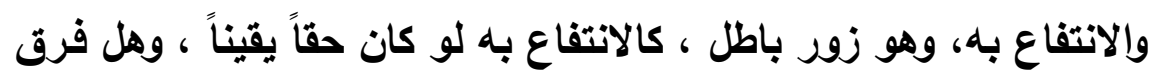
بين لذة الخيال في حال تمثلها وتخيلها ويين لذة اللقاء الصحيح والوصسال

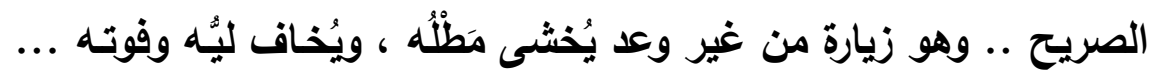

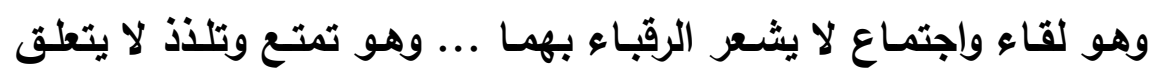


بهما تحريم ، ولا يدنو إليهما تأثثم " (1)

ولكنتا ويعد مضي ثلث القصيدة نقرأ فلا نجد شيئا من طيف الحبيبة ، ولا

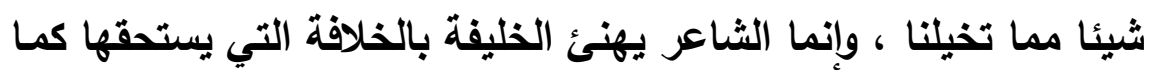
كان يستحقها أبوه حيث يقول :

سـنـن النبــي حرامهـــا وحلالهــا

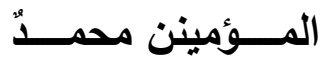

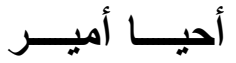

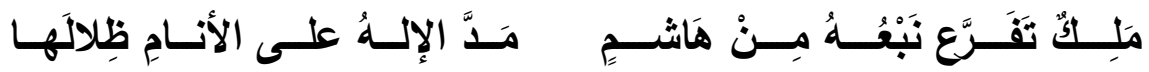

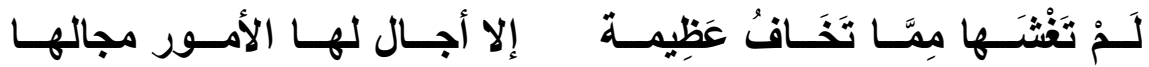

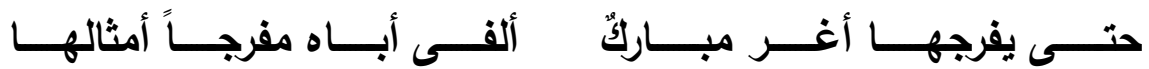

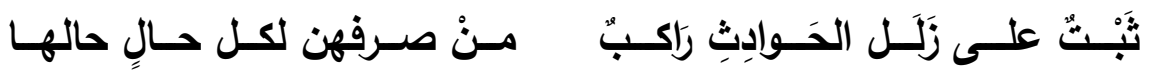

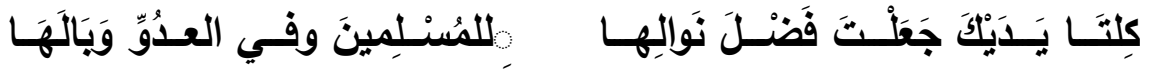

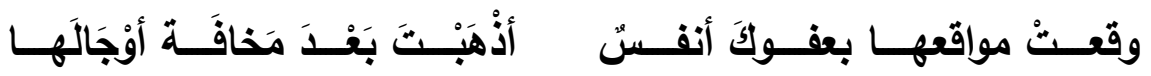

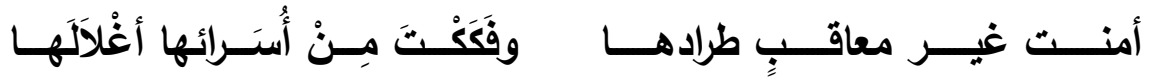

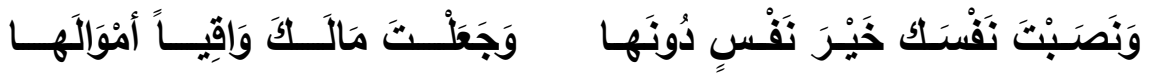

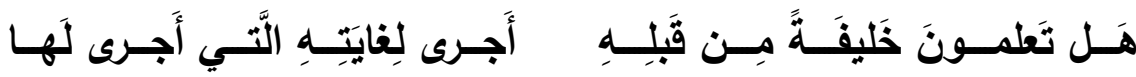
لقد سلك مروان بن أبي حفصة سبيلا مختلفا وطريفا في المدح في آن

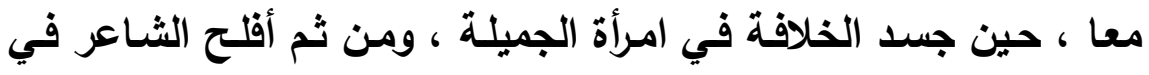

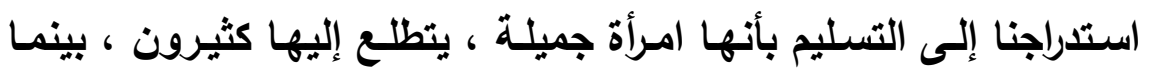

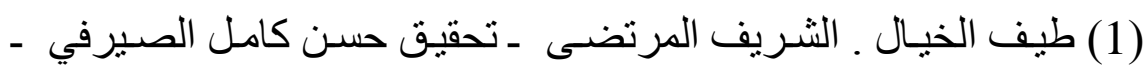
الهيئة العامة لقصور الثقافة ( الذخائر ) 175 ـ. 
أساليب الاستـــراج في القصيــدة العربيــة

د. عب الميدمحمد بلران

تتوق هـي إلى رجل وإحد ، هو الخليفـة المهدي ، وفي سبيل تحقيق

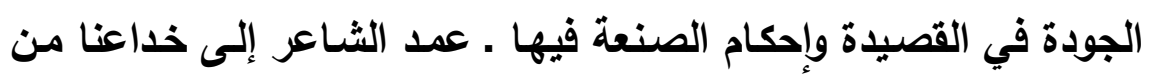
خـلال الخضـوع لإغراءات الصـورة التـي يريــ رسمها ، فمن طروق طيف الخيال ، إلى العشتق ، إلى الحلّم بـالزواج الذي يشترك فيه كثيرون مـع الخليفـة ، شـأن كل جميلـة تجد لهـا في كل قلب مكانـا ، إلـى التصريح بالغرض الأساس وهو التهنئة بالخلافة . ومن ثم كانت مقدمة القصيدة مرتبطة بالقصيدة ذاتها ، وترشـح لما حوته من مضامين لم يكن التركيز عليها لونا من الترف القني ، وإنما كان لونـا من التلطف في السباحة بالمتلقي في آفاق بعينها ، ثم مباغتته بالصحو مع غرض القصيدة الأساس. 


\section{المبحسث الثالث}

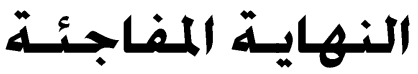

معلوم أن المفاجأة عنصر قصصي أصيل ، يعتمد عليه القاص في إثارة القارئ وجعله في حالة استبطان وتوتز مستمرين ، بما تثيره المفاجأة فيه من حدس يستطيع من خلاله أن يتخيل الوقائع والأحداث التي لـ يرها أو يقرأها صراحة ، في ضوء ما جدّ من أحداث غير متوقعة . وهذا اللون من التشويق القصصسي عميق في باب الاستدراج ، ذلك أن الشاعر يمضي في القصيدة حتى يصل إلى منتهاهـا دون إفصساح من أي لون ، حتى يصل مع آخر نفس فيها إلى لب القضية ، وسبب القصيدة التي يمكن أن يكون سؤالا أو صمتا عن إجابة أو غير ذلتك ، على النحو الأي يبدو مثلا في قصيدة عمر أبي ريشة (في طائرة)، حيث كان الثـاعر في الطريق إلى التشـيلي وكانـت إلى جانبه في الطـائرة فتـاة إسبانية ، تحدثه عن أمجاد أجدادها العرب القدامى ، دون أن تعرف جنسية من ون تحدثه ، فكانت قصيدته التي يقول فيها : (1)

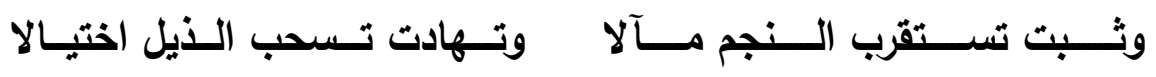
شـــعرها المـــائج غــنـجا ودلالا وحيـــالي غـــادة تلعـــب فــــي

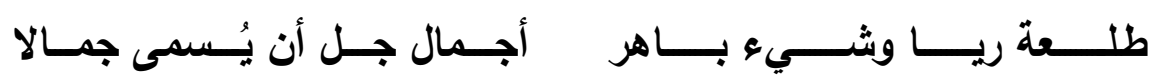

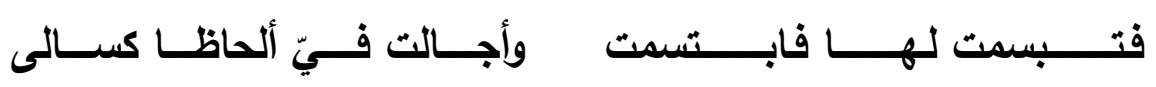
وتجـــــــبنا الأحساديــــث فــــما انــفضت حسـا ولا سـفت خيـالا

$$
\text { (1) ديوان عمر أبو ريشة ـ دار العودة ـ بيروت 1988م .صـ 89- } 92
$$




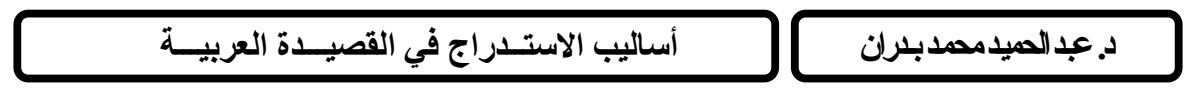

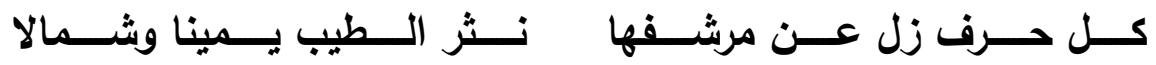

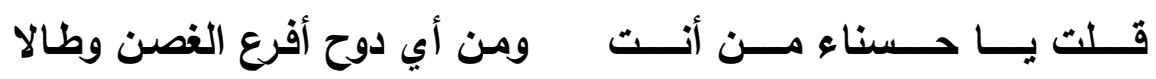

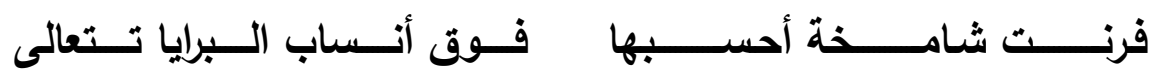

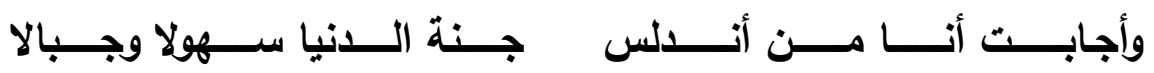
وجــدودي ألــمـح الــدهر عــلى ذكــرهم يـطوي جناحيــه جـلالا

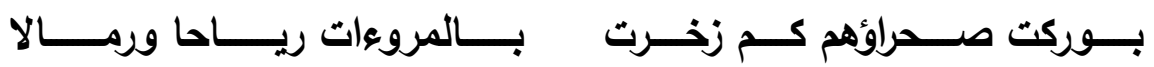

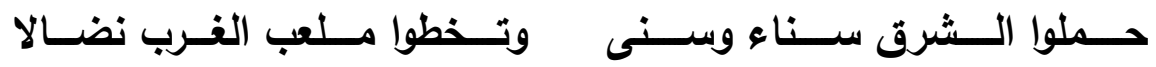

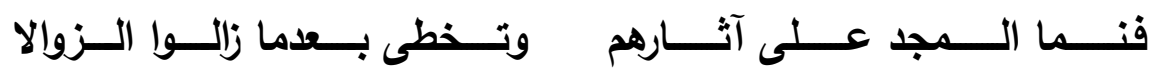
هــوَلاء الــصيد قـومي فانتسـب إن تـجد أكـرم مـن قومي رجـالا

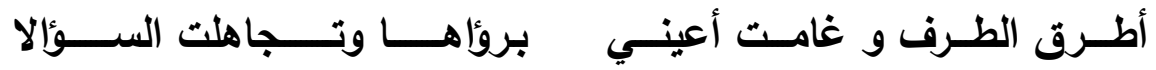
فأبو ريشة ق أفلح في استدراجنا بحرفية عالية ، لنصل معه في النهاية إلى الغاية التي رسمها وخطط لها سلفا ، عن طريق شغلنا بحكايـة غزلية ، وتسلية يراد بها شغل الوقت وجذب المخاطب والقضاء على الملل ، ومن ثم جاء نسيج القصيدة في صورة قصة جيدة بينه ويين فتاة أخذ يتجاذب معها أطراف الحديث في رحلة جوية بالطائرة ، ومـع إعجاب الرجل برزانـة المرأة وجمالها يستقر على شفتيه سؤال طبيعي في مثل هذا الموقف :

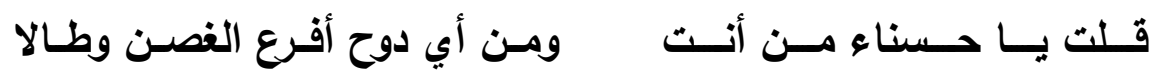
ولكن التقدمة لهذا السؤال بقوله : (من أنت ؟) يعكس مدي حيرة الثـاعر في استكناه حقيقة هذه المرأة الشـامخة ، وإمكانية أن تكون منتسبة إلى 
غير لغتها التي تنطق بها ، ومع استهجان نغمة السؤال من الرجل تطلب المرأة من الثاعر أن ينتسب ، وهو العربي خالص العروية ، فما كان منه

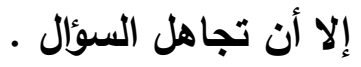

لقد أفلح الشاعر في استدراجنا من الحادث الغزلي الوديع إلى قمـة الجرح ومكمن المأسـاة وهو التذكير بالماضسي العريسي المجيد والفخر بـه ، مـع نهايـة هذه القصـة الغزليـة ، إذ إن فلسفة الفخر التـي غلفت كـلام المـرأة الأندلسية رغم ما حل بالأرض من نكال ومحو للهوية العربية الإسـلامية ، وكل ما يمت لها بصلة ـ هذه القلسفة الفخريـة قد أخرست العربي الأصيل الأي لم يقدم لعرويته وإسلامه ما يستحق أن يأكر ، ومن ثم تم " تحويل النص من غزلية لاهية إلى لوحة شعرية نازفة ، لأن ضمنية الصمت في

نهاية القصيدة هي التي حولت النص من الغزل إلى الجرح " (1) كل هذا يجعلنا نقر بأنه مـع ظهور غرض القصيدة في نهايتها واستمرار المتلقي معها في حالة تأهب واستبطان ـأنها تمـارس لونـا من الخداع الفني الأي يستعين بحرفيات القصة في الإبقاء على روح التوتر والتشويق في النص الأدبـي ، في الوقت الذي يـتم فيـه التسليم بهدف القصيدة بحرفية ومهارة ، عن طريق الاستدراج الفني القصصي الجيا . وعلى النحو ذاته يمكنا أن نقف على قصيدة (العنقاء) لإيليا أبي ماضسي ، حيث يبدو بداية أن موضوع القصيدة هو البحث عن حقيقة الروح كما بحثها الفلاسفة الأوائل ، ولكن الثاعر هنا أدار قصيدته في قالب قصصي جيد ، حيث بـأها بإبداء هيامـه بالمحبويـة ، والسـؤال عن كنهريا حيث

(1) في النص الثعري الحديث صـ 247 . 
أنــا لســت بالحســناء أول مــولع هي مطمع الدنيا كما هي مطمعي فاقصص علي إذا عرفت حديثها واسكن إذا حـثث عنها واخثـع

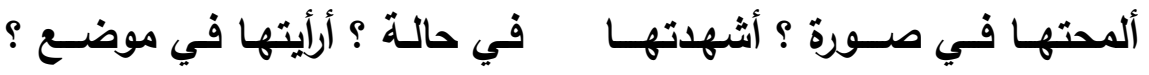

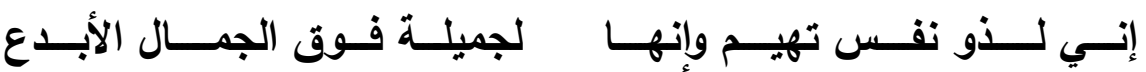

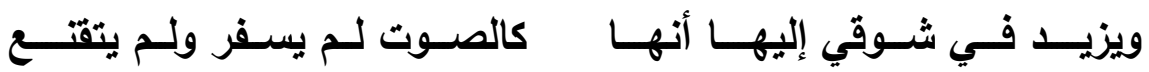
ثم يأتيه الجواب بأن عليه أن يتورع عن البحث عنها ، لأنها محجويـة

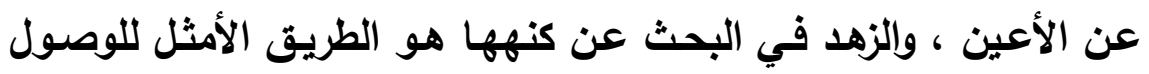

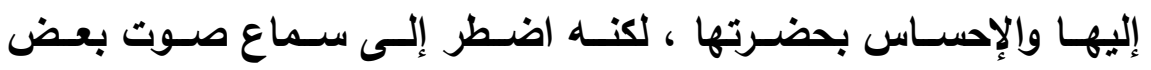
الناصحين بمتابعة البحث ، ومن ثم كان الندم ، حيث يقول :

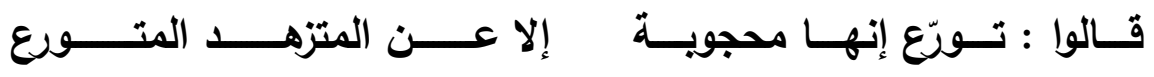

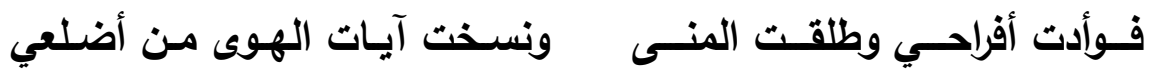

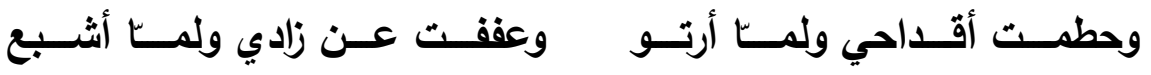
وحسـبتني أدنـو إليهـا مسـرعا فوجـدت أنسي قـ دنـوت لمصـرعي

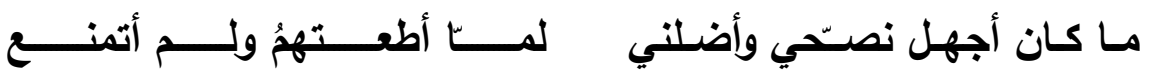

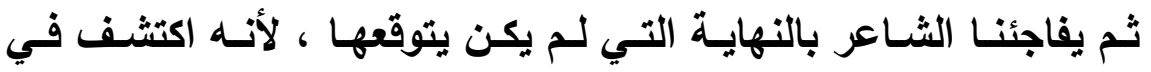

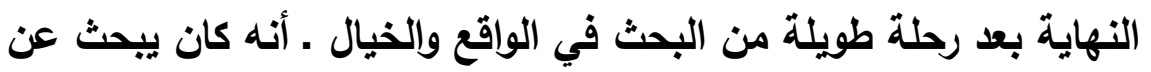
نفسه التي بين جنبيه ، حيث يقول :

$$
\text { (1) ديوان أبي ماضي ـ دار العودة } 1996 \text { صـ } 492 \text { ـ } 494 \text {. }
$$




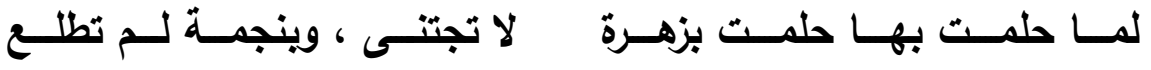
ثـم انتبهت فلـم أجـد في مخـدعي إلا ضــلالي والفـراش ومخـــي وعلمت حين العلم لا يجدي الفتى أن التـي ضــيعتها كانــت معسي ويبذو إلحاح الثاعر عمر أبو ريشة على استخدام هذه التقية في كثير من قصائده (1) ، تعبيرا عن المفاجآت التي تطلع على العربي الحر كل حين ، لتنهش عربيتهـ ، وتهين كرامتـه ، وتثبط عزيمتهـ ، فعن طريـق الرمز مثلا يفلح أبو ريثـة في توظيف تقنية الاستدراج بواسطة النهايـة المفاجئة في قصيدة (نسر) ، حيث لعبت دورا في تجسيد مأسـاة الإنسان القوي في صراعه من أجل البقاء ، حين سلط الضوء على نسر ضعيف مريض ، تتلاعب به ضعاف الطيور فيقول : (2)

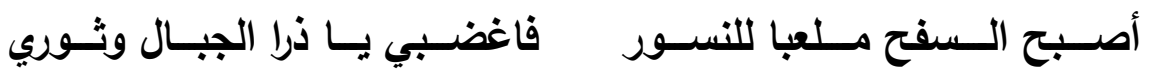

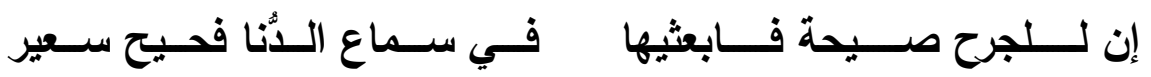

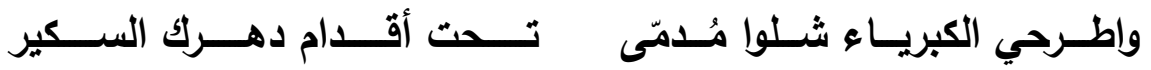
وكأن الثاعر يقول للنسر : إن مكانك أيها النسر فوق قمة الجبل ، فكيف نزلت إلى السفح؟ ثم يعزي ذرا الجبال عن فقده بصـورة سـاخرة مهينـة

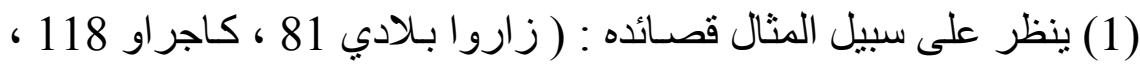
هيكلي 187 ، زنبقة 308 ، حسبي 337 ، مظــاهر 369 ، ، النسـوة الثنلاث

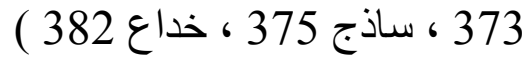

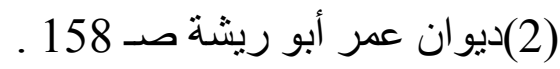
(3) (3) السابق صـ 159 . 


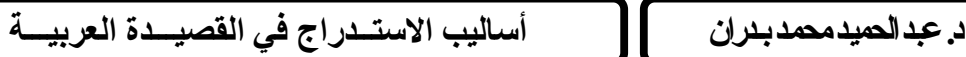

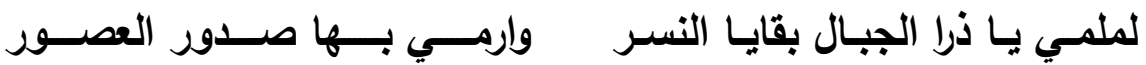

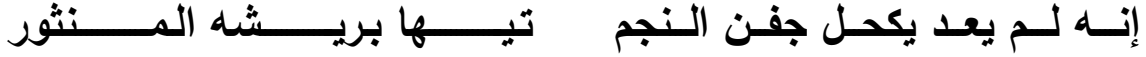

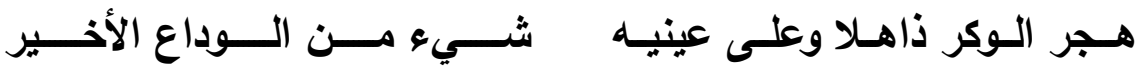
تـــاركا خــلفه مـــواكب ســـب تــتهاوى مــن أفـقها المسـحور

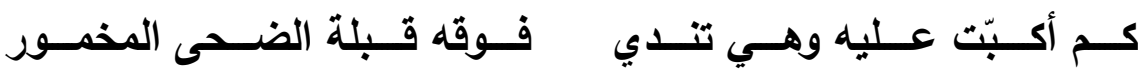
هـبط السفحح طاويـا مسن جناحيـه علــى كــل مطــــح مــقبور فـتبارت عصـائب الطير مـا بـين شـــــرود مـــن الأذى ونـــفور

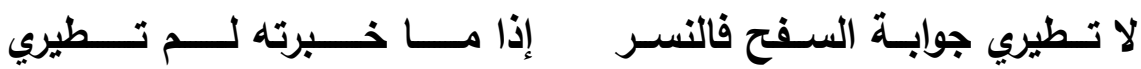
نـسل الـوهن مــلبيه وأدمــت منـــكبيه عـــواصف الـــمقدور والـــوقار الــــي يسـشيع عــليه فضـلة الإرث مسن سـحيق الــهور وقــف الــنسر جــائعا يــتلوى فــوق شــلو علـى الرمسـال نثيـر وعجــــاف البغــــاث تـــــفعه بالمخلب الغض والجنـاح القصير ولكن كبرياء النسر ما لبث أن استبد به ، فصمم على إعادة كل مجد تليد ، فصعد قمة الجبل وألقى بنفسه ، لكن هذا الصعود كان مؤذنا بنهايته ، على ما يوضحه قول الثاعر : (1)

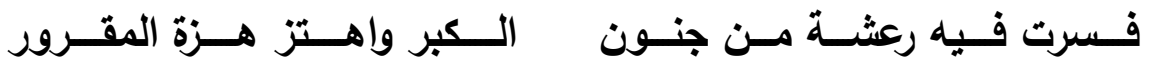
ومضس سـاحبا على الأفق الأغبر أنقـــــاض هيـــــل مــــنذور (1) السابق صـ 161 ، 162 . 
وإذا مــا أتــى الغياهـب واجتــاز مـــى الـظن مسن ضـمير الأثيـر جـلجلت منـهـ زعقـة نشــت الآفـاق جـرى مــن وهجهـا المسـتطير وهـوى جثـة على الـذروة الشـماء فـي حـن وهجهـا المسـتطير أيـها النسـر هـل أعـود كمـا عدت أم الـسفح قــــ أمسـات شـعوري إن محاولـة استعادة الأمجـاد حتى مـع نهايتها المأسـاوية بالفشـل كانـــ هاجس أمل دفع الثاعر إلى استدراجنا إلى كنه القضية في البيت الأخير، فقد نقلنا الشاعر من محيط قصة الطير وفلسفة القوة الحيوانية إلى الواقع المرير الذي نعيشه ، بحيث أصبحت كل الحوادث القصصية السابقة. على هـ الرغم من حدوثها حقيقة كما صرح هو في لقاعات مسجلة ـ حورات رمزيـة مسقطة على الواقع ، من أجل تقرير أن الموت في عز أهون من العيش في ذلة ، وقد رشـح اختلاف الضمائر في البيت الأخير لهذه الإسقاطات حيث انتقل الشـاعر مـن ضمير الغائب إلى ضمير المـكلم ليشـاكل بين القصة والحقيقة والواقع والخيال ، مع التأكيد على مرارة وقع (العودة) في قوله (هل أعود) ؛ لأنه كان مسافرا كسفير لاولة أجنبية ، ويغلبه حنين جارف إلى وطنه الأي لم يفارقه بعد . وقد تكون النهاية المفاجئة أقرب إلى حل لغز مبهم ، عمل الشـاعر على حبك قصته وتوظيف شخصياته وأحداثـه ، على التحو الذي تبديـه لنـا

قصيدة إيليا أبي ماضي التي عنوانها : (هي) وفيها يقول : (1)

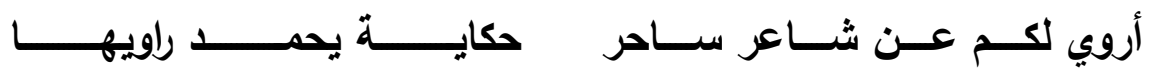

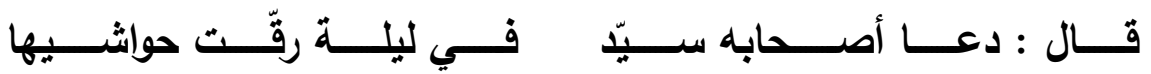

$$
\text { (1) ديو ان أبي ماضي } 811 \text { - } 813 \text { - }
$$




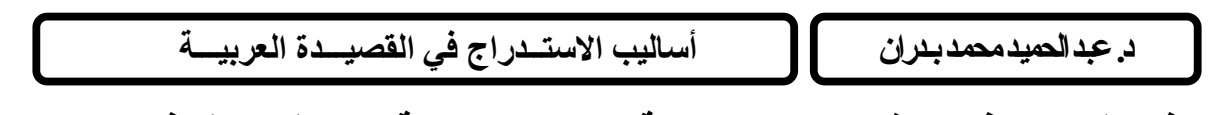

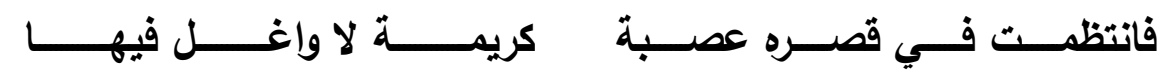

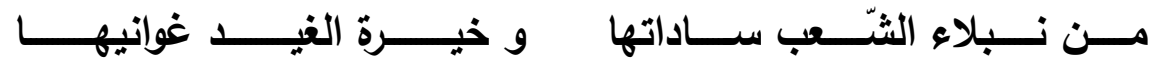
حتّـــى إذا مــــا جلســــوا كلّهــــم و طــــاف بـــالأكواب ســــاقيها

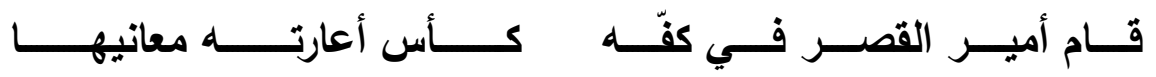

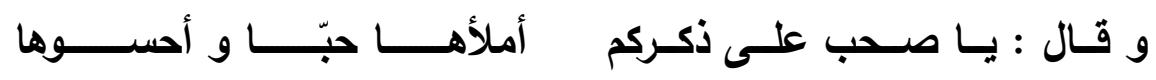

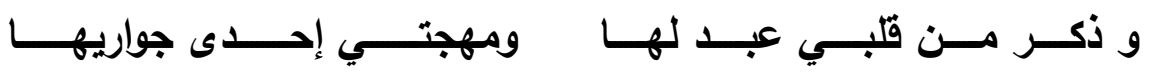

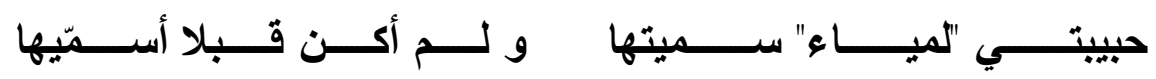

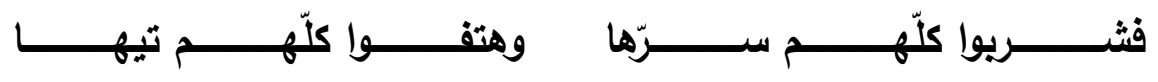

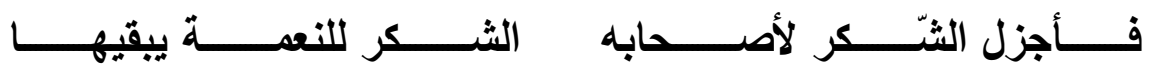

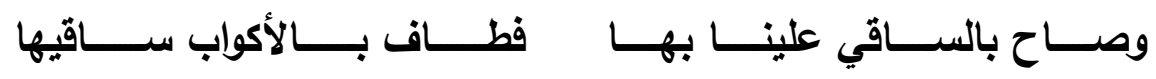

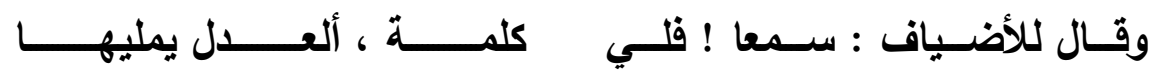

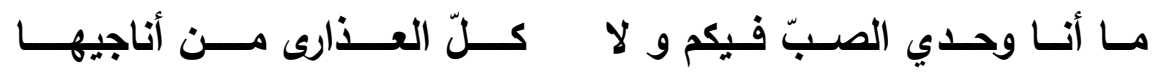

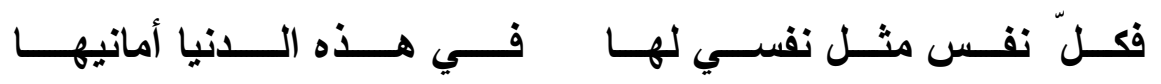

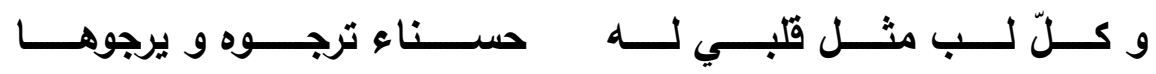

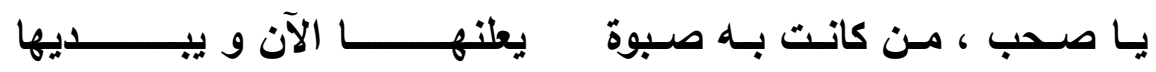

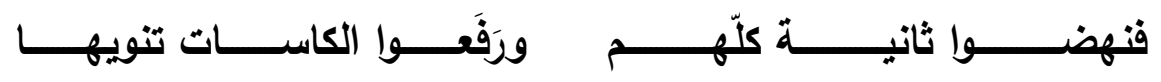

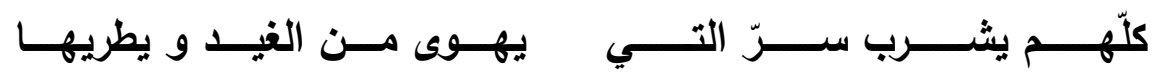




\section{إصدار 2017}

حولية كلية اللغة العربية بالمنوفية العدد الثاني والثلاثون

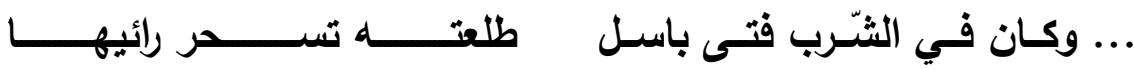

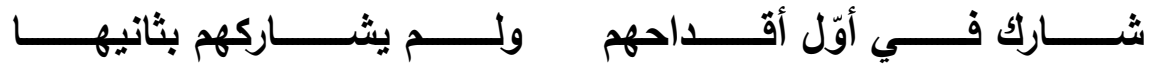

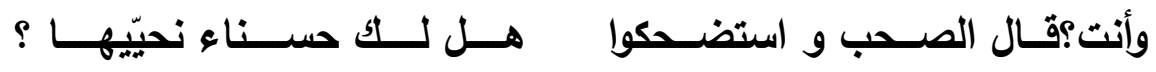

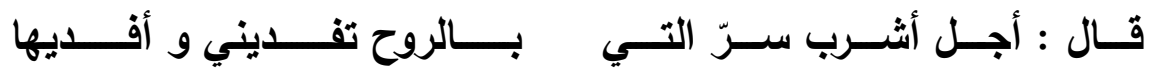

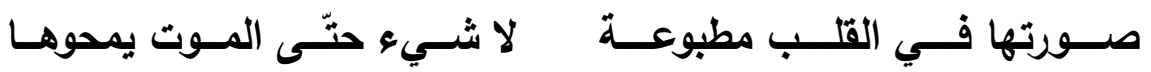

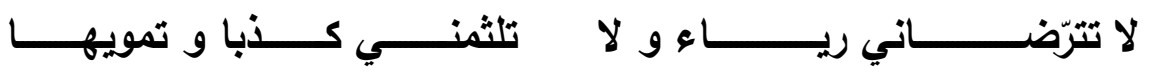

لقد ظهرت ملامـح القصـة كاملة عند إيليا ، بكل شخصياتها وملابسـاتها وخلقياتها الماجنة ، ويـات الكل في شوق لمعرفة حبيبته التي بـالغ في تقديسها ، لارجة استفزت الحضور ، فمنهم من كظم غيظه ، ومنهم من رماه بالخبل ، حتى تدخل رب الدار لحل القضية سائلا :

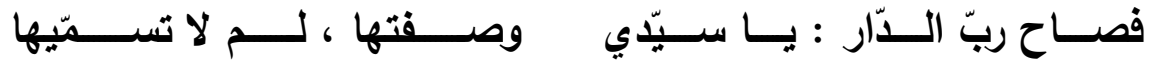
أتخجــلـل باســـم مـــن تهــوى ؟ أحســـــاء بغيــــر اســـــم ؟

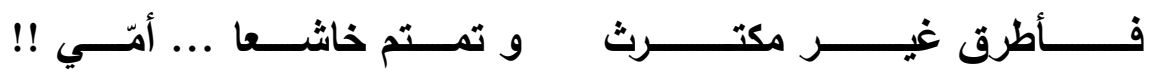
إن المفاجأة في كلمة (أمي) قـ أتت على كل قول ، فكمّ التضحيات التي تقدمها الأم في أي زمان ومكان أظهر من أن يثار إليها ، ومن ثم بالغ الثـاعر في رسـم صسورتها في القلب ، ولمّا تاقت النفوس إلى معرفة الحبيبة الخيالية هذه ـ ضرب الشاعر ضريته وكشف اللثام ليحقق الإقاقة التامة ، منبها إلى حبيبة طالمـا هضمت حقوقها وتضاعلت صورتها أمسام

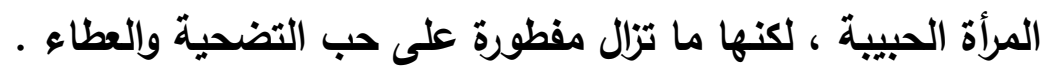
كما أن المفاجـأة لـم تكن في هذه النقلـة العاطفيـة الفكريـة التي مارست 
الدعوة بحرفيـة وذكاء ، عن طريق المشـاركة في الكأس الأول ، وعدم المشاركة في الثراب بعد ذلك فقط ، وإنما في النقلة الموسيقية التي تغيّر معها (روي) القصيدة ، تمهيلا للتغيير الفجائي من (الهاء) الى (الميم) ،

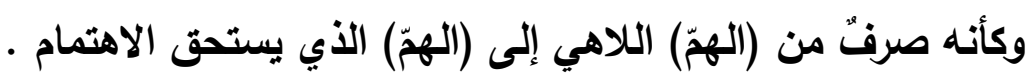
وقد تثمثل المفاجأة في مفارقة الحبكة الارامية في قصيدة القصة ، حيث ينتهي المشها إلى عكس ما ترشحه الأحداث ، على النحو الأي يبدو في قصيدة (المحاكمة) للثاعر الاكتور محمد أحمد العزب ، حيث استفاد من تقتيات المسرح من حيث وجود الثخصيات متمثلة في القضاة والجمهور والشهود ، والمنولوج الداخلي متمثلا في صوت الشاعر الأساس ، والحوار متمثلا في خلق مقابلة حواريـة بين شـعراء الطموح من أمثال : المعري والمتتبي وأبي نواس ، ليبين كيف يحساكم أصحاب الكلمـة في هذا الزمان

$$
\text { ها فيقول الثاعر : }
$$

ها أنا في الجُبّ مقطوع اللسان شاعر مات وفي عينيه جوع للحنان

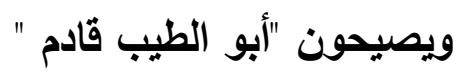
فأصلي تحت رجليه وأستجدى الأمان

وأبو الطيب يصغي ويقول :

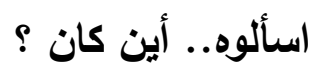
أين من خارطة الأحياء والأشياء كان . سيدي كنت أغنى في روابي المنتصف...

(1) الأعمال الشعرية الكاملة د / محمد أحمد العزب صـ 532 . 
حولية كلية اللغة العربية بالمنوفية العدد الثاني والثلاثون

ولقد كنت طموحا مثثما كنت وأكثر

غير أني لم أكن أحلم في ملك ولا حتى نبوة!!

وياخل المعرى ليشهد للشاعر بالبراءة قائلا :

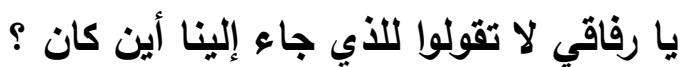
أين من خارطة الأحياء والأثثياء كان ؟

حسبه قد كان في الانيا...وفي قلب الزمان .

عنصرا يقتات منه عنصران !!

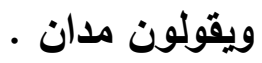

خفقوا الوطء فما للحرف والشاعر في المأساة يا قوم يدان !! ويدخل أبو نواس سائلا عن حال الثـعر والخمر والمُرد والِغِيد فيهه ، ويـرد الثـاعر عليه بأنسه متهم بقتل هذه الأثـياء ، وهنـا يكشف الثـاعر عن شخصيته الخادعة التي استـرجت هولاء الشعراء لإدانتهم بالتعاطف مـع

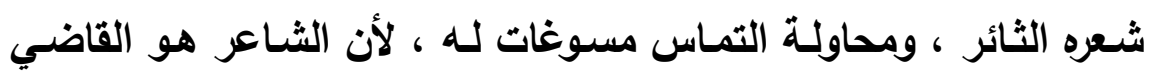
الأكي الأي سيحكم عليهم : وأنا القاضي الأي استدعى شهودا من ورق ليدين المتنبي والمعري والنواسي الجبان وهناك لون جيذ من النهايات ، يشبه إلى مدى بعيد مـا يسمى في القصـة بـ (النهايـة المفتوحسة) ، حيـث تتتهـي القصـة دون أن يتوقـع القـاريء انتهاءهـا ، ويتم ذلك عن قصد مـن المبدع في إحداث الصدمة القنيـة للمتلقي ، ومـن ثم يـأتي الصـحو مـن هذه الصدمة عن طريـق افتراض المتلقي ما كان ينبغي أن يراه من أحداث ، وعلى هذا النحو تأتي قصيدة 


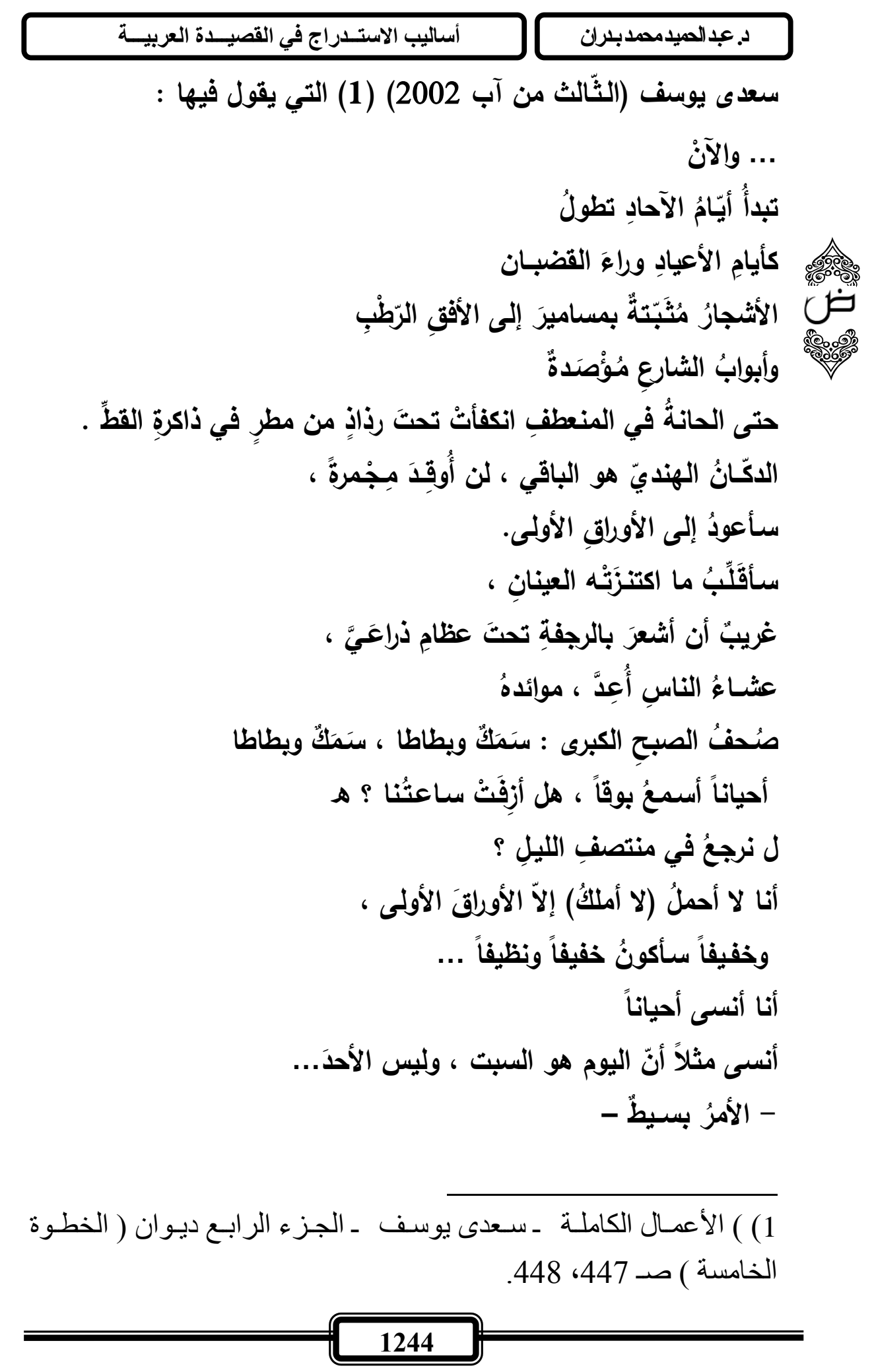


فالثاعر قد تركنا بعد رسم المشهـ اليومي المتكرر مع الثرفة المفتوحة ، الثها

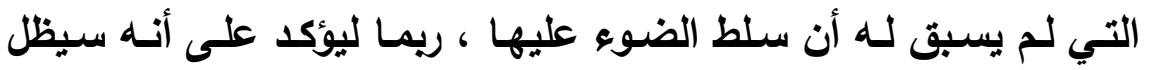

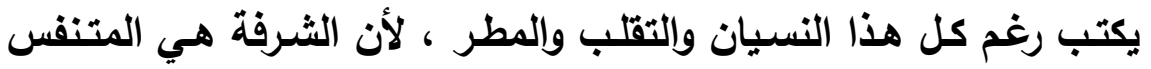

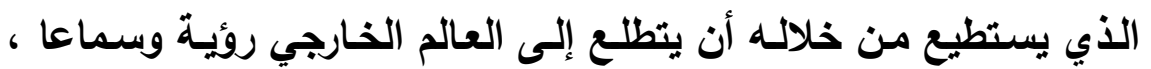

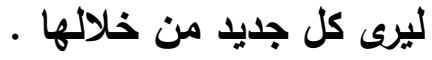
إن العطلة في الآحاد قد حولت المشاهد إلى مشاهد صامتة ، أثبه بلوحة

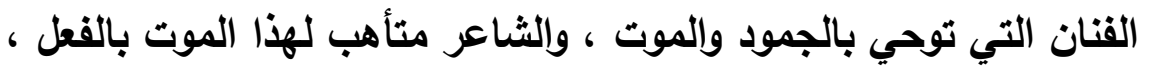

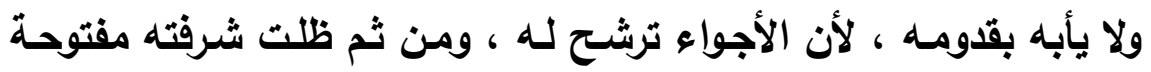
في انتظار الجديد المدهش . ولعل وعي الثاعر المبدع وإدراكه مدي الرتابة التي يعيثها القارئ مع جل القصائد العربية المقلدة - لعل هذا الوعي كان الحافز الأكبر في ابتكار

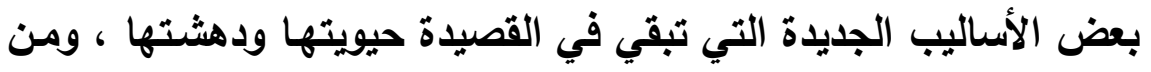

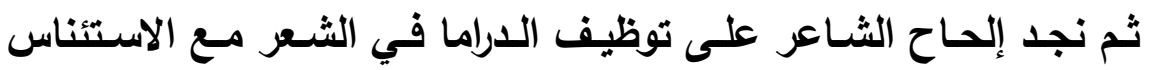

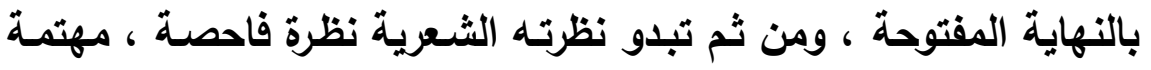
بالتفاصيل الصغيرة ، والمكان والحدث والثخصيات ، على النحو الذي الذي 
يبدو مثلا في قصيدة سعى يوسف (نظرة جانبية) التي يقول فيها : (1)

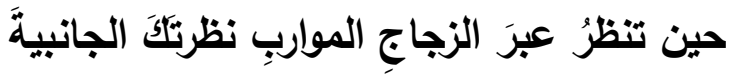

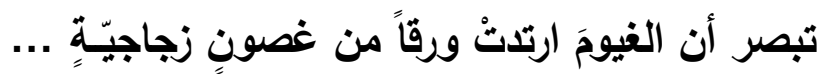

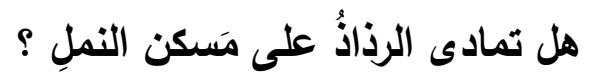

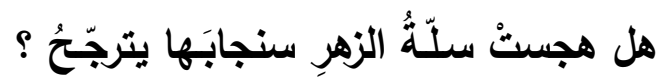
هل كنتُ أهذي بأسماعِ مَنْ رحلتهْ أمسِ

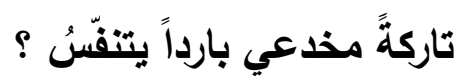

كان القطاز

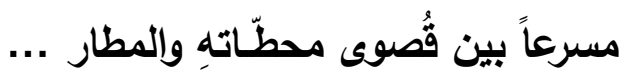

1) ) الأعمال الكاملة ـ سعدى يوسف ـ الجزء الخامس ديوان ( حفيد امريء القيس ) ـ منشور ات الجمل ـ بيروت 2014 م ـ صـ 175، 176، 176 17، وتنظر قصيدته (اغتيال ) التي يقول فيها :

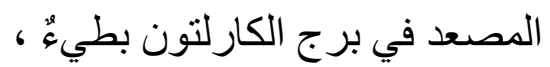

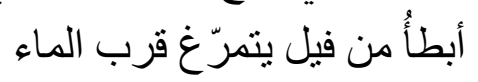
المصعد يهبط. ينفتح الباب وينغلق الباب

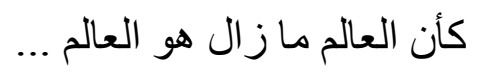

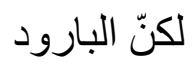
سيظل طويلاً في رائحة المصعد لئد

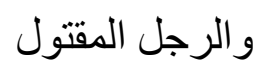
سيظل طويلاً في غرفته العليا ... سلرول ينظر الأعمال الكاملة الجزء الثالث (جنة المنسيات) صـ 377 
أسمعُ الآنَ صوتَّ الرذاذِ الذي صار في لحظةٍ مطراً

أسمعُ الطائراتِ ...

الصواريخُ تنقضُّ الصنُ

إنـي أُقِيمُ الصنّلاة

إن الشـاعر يحـاول إسـقاط مشـاعره علـى مفـردات الحيـاة مـن حولـهـ ، فيتسـاعل وهو ينظر من خـلال النافذة ، غير واثثق من الروئية الحقيقيـة للأثياء بعد رحيل حبيته أمس ، إنه لا يارك مـا إذا كانت الغيوم مـا تزال ترتدي أوراقا زجاجية ، والرزاز ما يزال ينزل على مسكن النمل ، والسنجاب ما يزال يترنح فوق أغصان الزهر ، ثم ينتقل من خـلال المسـافة البيضـاء التي يملؤهـا بـالنقط الصغيرة ـ إلى مشـه آخر للشـاعر وقد أيقن أنـه في القطار ، بما يشعزنا بأنه ليس على يقين من تحقق المشهر الأول ، فهو بالنسبة لـه كـالحلم الذي أفـاق منـه على صـوت مطر حقيقـي وطائرات وصواريخ حقيقية كنلك .

ومن خلال المسافة البيضاء التي يملؤها بالنقط الصغيرة ـ يفاجئنا الثـاعر بعبارة (إني أقيم الصلاة) ليترك لنا مساحة من التخيل والحدس في البحث عن سر هذا الربط الغريب ، الذي قد يكون دعوة إلى الصـلاة حتى في القطار ، من أجل تحقيق أمل الشـاعر في أن يعود السكون مخيمـا على هـى

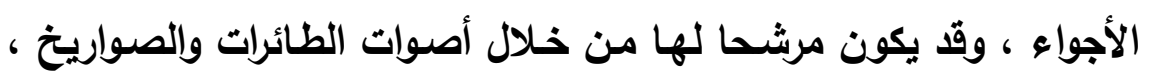




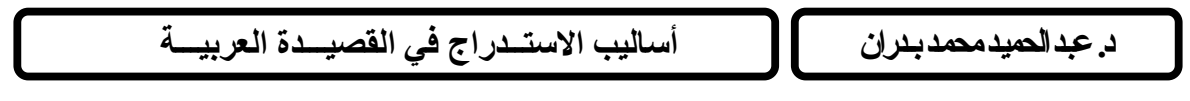

وكأنها نواقيس الكنائس ، ليشـاكل التطور الذي اقتضـاه الوضـع الراهن ،

أو ليتحقق أمله في عودة حبييته التي تركت مخدعه باردا يتفس . 


\section{المبسحـ الرابع

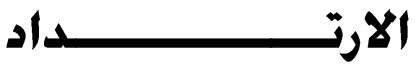

عرف الارتداد (1) في النقد بأن يبدأ الثاعر قصيدته من نقطة معينة من وسط الأحداث أو نهايتها ، ثم يعود إلى حدث سـابق يـرى أنـه أقل منـه دراميـة ، أو أقدر علـى ربـط الحـدث السـابق بـالاحق ، أو يحمـل مـن الدلالات ما يرى القاص أو الشاعر أن يقتحم بها ذهن القارئ أولا ـ (2) وهو تقتية قصصية جيدة ، حيث رأى النقاد أن " الترتيب الطبيعي للأحداث من حيث البدايـة والوسط والنهايـة ينبغي ألا يقف حجر عثرة في سبيل حرية الروائي في عرض أحداثه ، فقد يبدأ من نهايتها ثم يرتا بالزمن إلى الماضي كاشفا عن الجذور بفعل منطق السبيية ، أو استرجاع الذكريات

(1) الارتــداد إلى الماضـي : مصطلح يستخدمه المسرحيون و القصاصـون

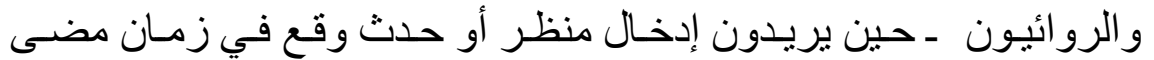

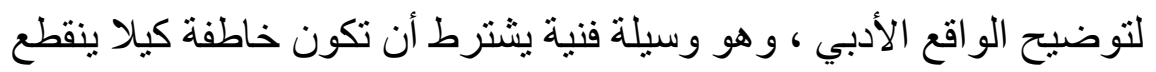
سياق مجرى الأحداث... و هو ما يدعى عند الغربيين ( الفلاش باك ) ) ينظر :

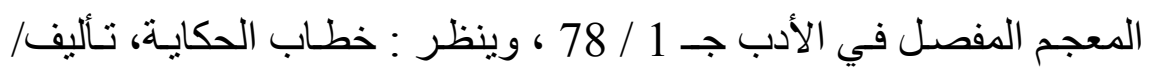

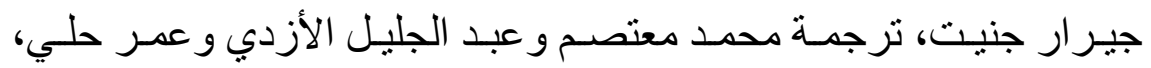

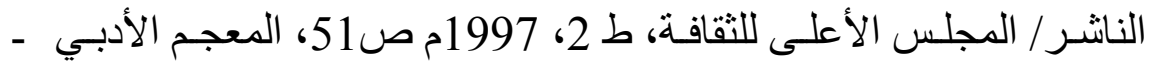

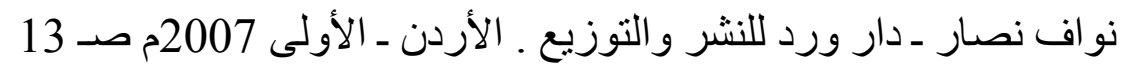

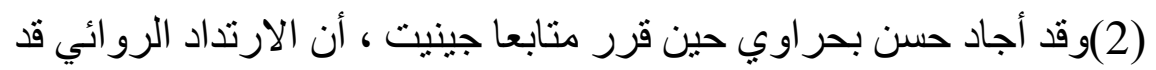

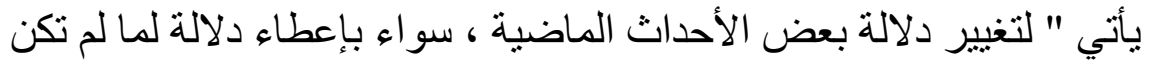

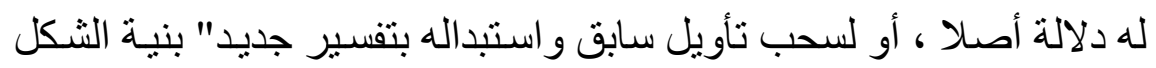

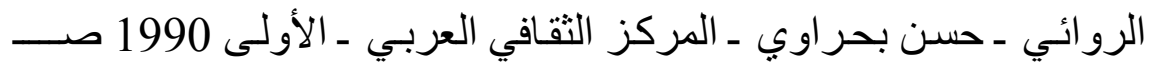




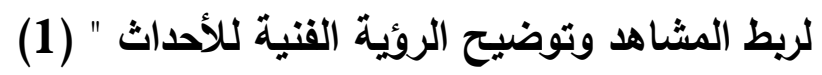
وقد استعار الشـاعر هذه التقتية من فن الروايـة وطوعها لطبيعة البناء الثسري لايـه (2) ، ويرجع السبب في ذلك إلى رغبة الروائسي ـ ومن ثم الثاعر • " في التركيز على الحدث ، وجعله بؤرة الاهتمام ، وتحويل انتباه المتلقي من متابعة التسلسل التقليدي وماذا بعد السبيية والكيفية في لماذا ؟ وكيف ؟ ، وهذا يعطي الأحداث حركة وحيويـة ، ويثير خيال القارئ في انتقـال الأحداث مـن الحاضـر إلى الماضـي ثـم العودة مسن الماضـي إلى

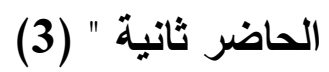
وفي شعرنا القديم مـا يؤكد وجود المهاد الحقيقي لهذه التقتية القصصية في صدر كثيز من القصائد ذات الصبغة القصصية ، على النحو الذي يبدو مثلا في صدر معلقة امرئ القيس ، حيث يقول : (4) منئ

(1) بناء الرواية د / عبد الفتاح عثمان ـ مكتبة الثباب 1982 م صـ 284 ـ عـاء

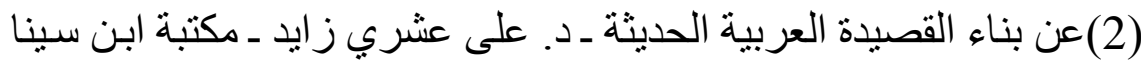

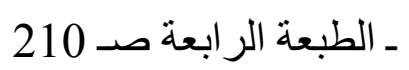
، وينظر : معجم المصطلحات العربية في اللغة و الأدب صـ 161 ـ 110

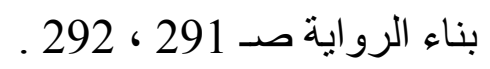
(4) ديوان امرئ القيس ـ دار صـادر صـ 29 ، و وينظر ديوان فئ عمر بـن أبي ربيعة في قصيدته التي مطلعها

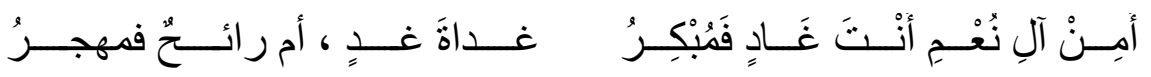

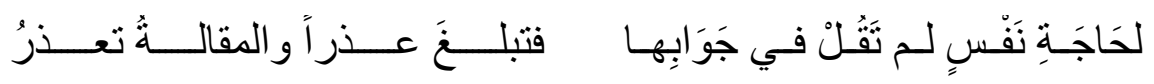

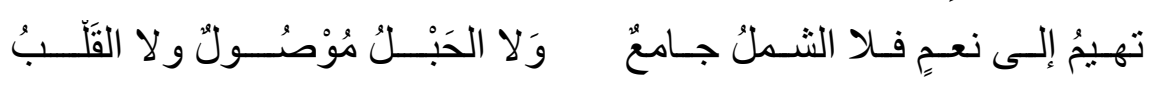
ديوان عمر بن أبي ربيعة ـ تحقيق د. فُايز محمد ـ دار الكتاب العربي الثانية 1996م صـ 122 
قفـا نبك من ذكرى حبيبٍ ومنزل بسقط اللوى بين الدخول فـومل فتوضـح فالمقراة لمن يعف رسمها لمـا نســتها مسن جنـوبِ وشـــأل

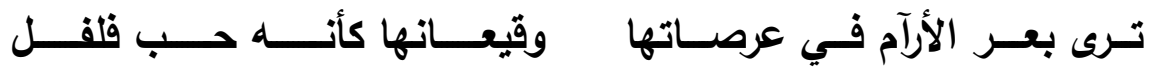

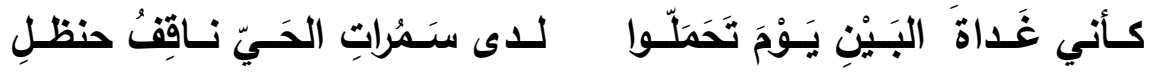

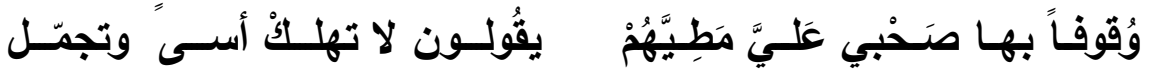

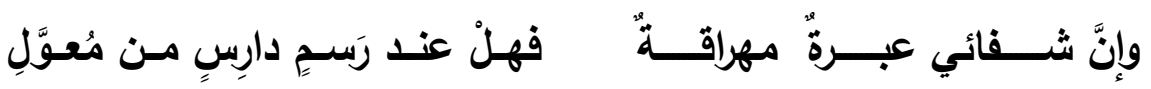

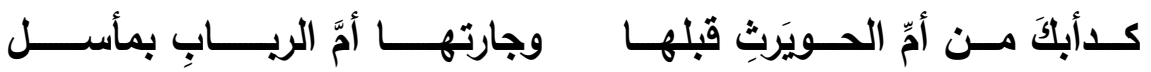
إن الشاعر في هذه اللحظة قد وقف يبكي ويستبكي ، من أجل أن يعود

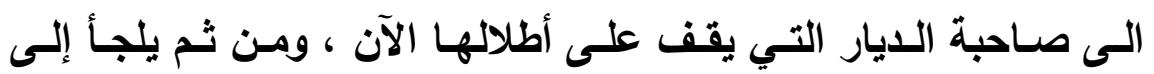
(الارتداد) لأنه الوسيلة المثلى لسرد تداعيات الموقف بتفاصيله الصغيرة ، لأن بهذه التفاصيل يكون الأنس الأي تحيا بـه اللحظة في الخيال حياتها الأولى في الواقع ، وهو الذي تحقق في سرد الشـاعر مغامراته بعد ذلك حيث يقول :

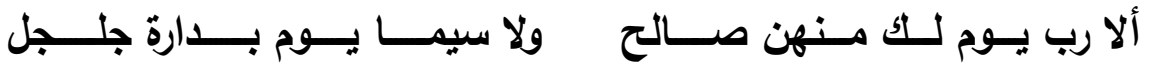
ويـوم عقـرت للعـذارى مطيتـي فـيا عجـبا مسن كـورها المتحمـل

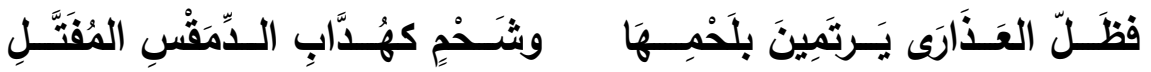

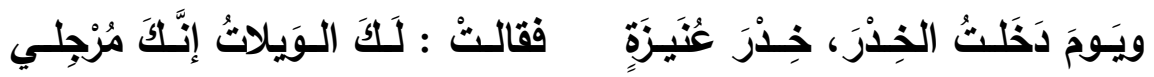

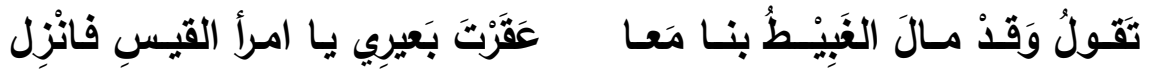
أما الشاعر في العصر الحديث فيبدو مقتنعا بدور هذه التقتية القصصية 


\section{أساليب الاستـــراج في القصيـــة العربيــة}

إن. عبد الميدمحمد بلران

في خلخلة النمطية في القصيدة كما هي في القصة ، ومن ثم سلط عليها الضوء في قصيدته ، وحملها من الأبعاد مـا استحق بـه أن يكون شـاعرا قاصا في آن معا . ويختلف موضـع الارتداد في القصيدة كما كان يختلف في القصـة تمامـا بتمام ، فمن الشعراء من يؤجل الارتداد لمرحلة ما في قصيدته ، ويعضهم يبدأ به ، ولكل وجهة في الاهتمـام بالحدث الارتدادي ، فممن آثر تأجيله لمرحلـة في القصيدة شـاعرنا عمر أبو ريشـة في قصيدته (لوعـة) التـي (1) : نقول فيها :

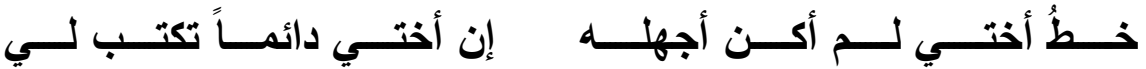
حـثثتي أمسس عـن أهلــي وعـن مضـض الشـوق ويُعــ المنـزل

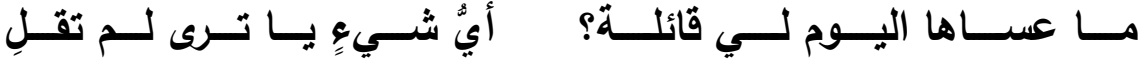
إن الشــاعر قد سـبح بخيالـه ، واستحضـر هـواجس متعـدة ، كمـا كـان يستحضرها في كل مرة تكتب لله أخته خطابا ، وقد أحسنا معه بطزاجة اللحظة ، وعشنا معه القلث والتوتر ، حتى وصلنا إلى المرحلة الثانية من الأحداث حيث يقول:

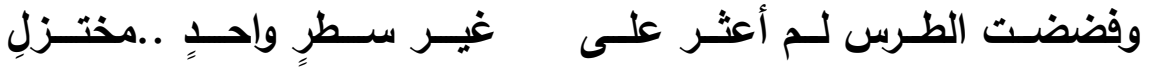

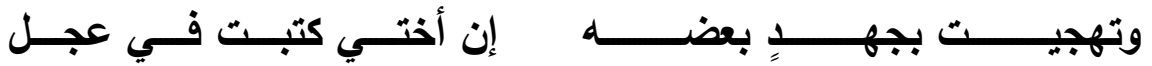

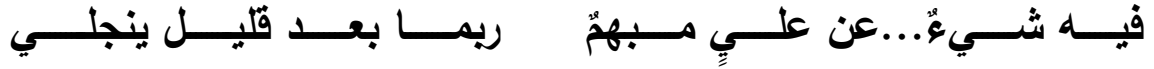
وتوقة 
لقد أفلح الشاعر في استدراجنا في هذه المرحلة ، ووضعنا في قلب الحدث ، نخاف ونحذر ، ونريد أن نطمئن على ابن أخته (علي) ، كما أفلح بعد ذلك في استدراجنا عن طريق الارتداد للوقوف على صورة الثخص الغائب

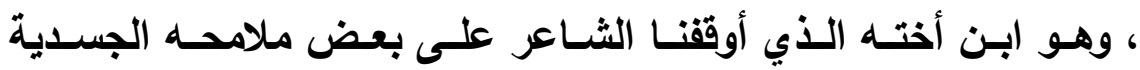
المتفائلة ، كما أوقفنا على طموحاته وإصراره حيث يقول : (1) مـنـ خيـوط الفجـر أســـى حُلَـلِ

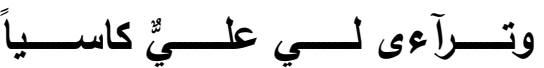
سـلس اللهجبــة حلـــو الخجــل

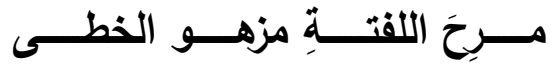

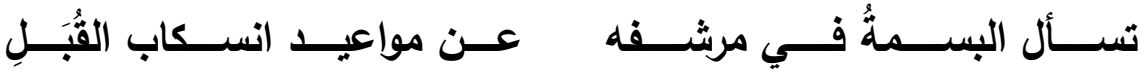

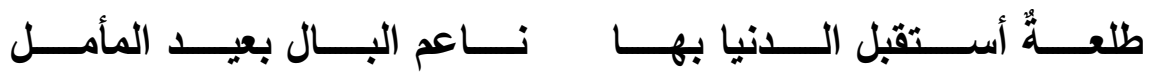

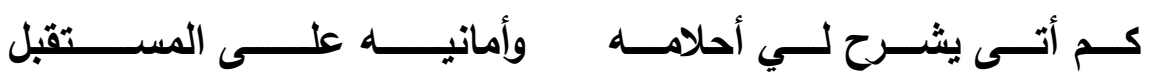

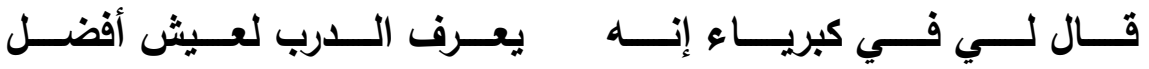

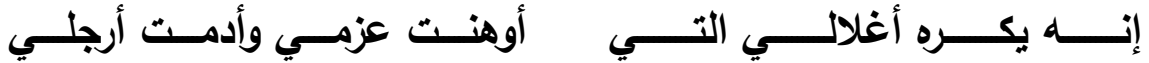

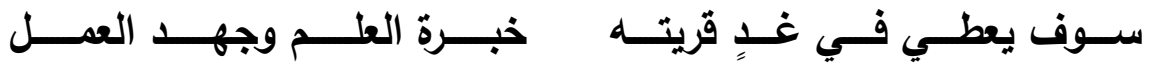
وســـيني بيتــــه فـــي غابـــةٍ

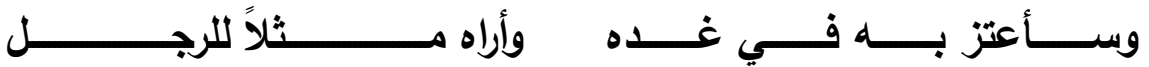
ثم ينهي الشاعر قصته بعد هذه الطموحات الجميلة بالنهاية المؤلمـة التي لم يصرح بها في القصيدة ، حيث تركنا في حالة ترقب من أجل معرفة

$$
\text { (1) } 396 \text { - } 394 \text { - } 394 \text { (1) }
$$




\section{أساليب الاستـــراج في القصيـــة العربيــة}

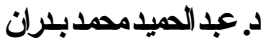

ماذا سبصير إليه (علي) حيث يقول : (1)

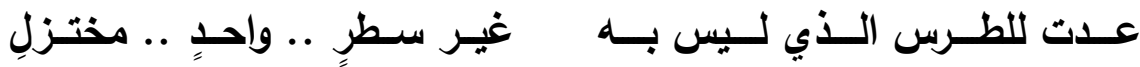

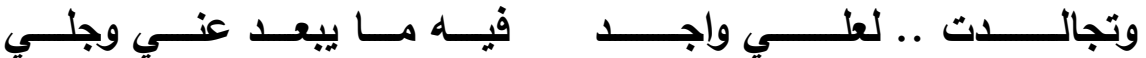

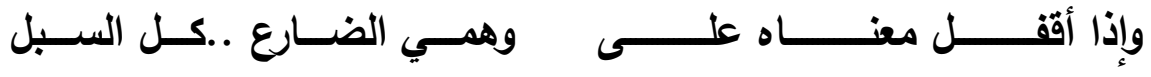

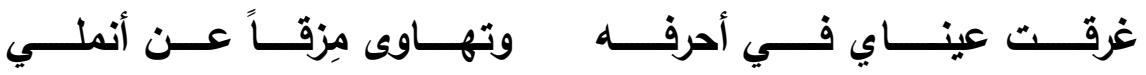

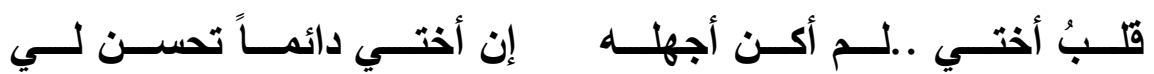

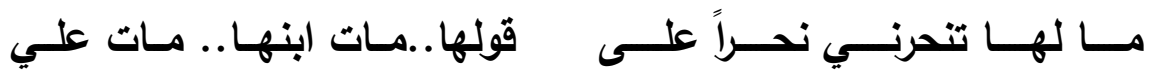
إنها عودة فنيـة إلى الطرس الذي يحمـل المفاجـآت والرجفـات ، بعد أن استخل الشاعر سوء الخط كحبكة درامية أبطأ معها إحساسنا بالوصول إلى نهاية متوقعة ، واستطاع بمهارة أن يطوف بنا مـع أخته وابنها في حين كان الثاعر مهموما بفك طلاسم هذا الخط ، غير أنه في طرافة قد أعطى صورة مشرقة لبطله الغائب الأي وقفنا على نبله وطموحه قبل أن نتعرف على صورته ، لأنه كان يطمح أن يعطي للحياة أملا وطموحا . ومن ذلك النوع من الارتداد قول أمل دنقل في قصيدته (البكاء بين يدي

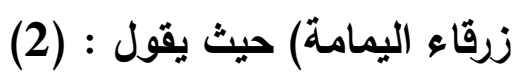
تكلمي ... لثثدَّ ما أنا مُهان لا اللَّيل يُخفي عورتي ... كلا ولا الجدران !

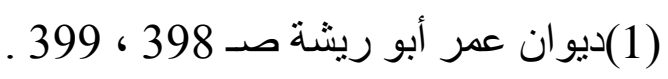

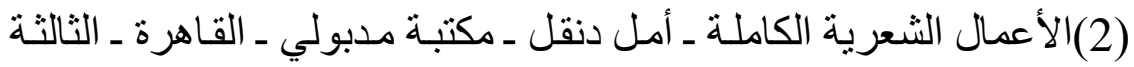

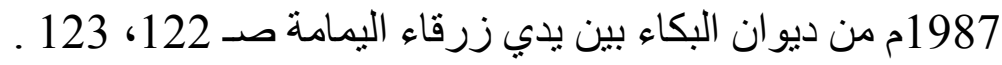



. . تقفز حولي طقلةُُّ واسعةُ العينين .. عذبةُُ المشاكسة كان يَقُصنُ عنك يا صغيرتي .. ونحن في الخنادْق فنقتح الأزرار في ستراتنا .. ونسند البنادق وحين مات عَطَشاً في الصحَراء المشمسة . . . رطبّب باسمك الشفاه اليابسة . . . وارتخت العينان !) فأين أخفي وجهيَ المنَّهمَ المدان ؟ والضحكةَ الطروب : ضحكتهُ.. والوجهُ . . والغمازتانْ ! ؟ ؟

لقد كان المتحدث في القصيدة "واحدا من الجنود الذين نجوا من معارك

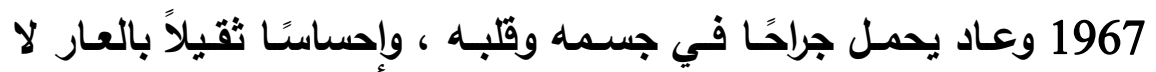
يستطيع أن يتخلص منه أو يخفيه ، فلا الليل يستر هذا العار ولا الجدران

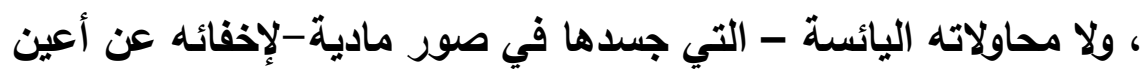
الآخرين ، ويزداد إحساسـه بالعار ثقلاً وكثافة حين يرى طقلة أحد رفاقه في الميدان من الأين استشهدوا عطشًا في الماضي ... ؛ فروئيته للطقلة تذكره بأبيها الشهيل ، فيسترجع مـا كانت تمثله هذه الطقلة بالنسبة لـه ، ولهم جميعًا - من خلاله- حيث كان حديث الأب عنها يتحول إلى نسيم وديـع يهب النسيم ، ويسندون بنـادقهم ، وحتى عندما استثــهـ واللدها عطشًا في الصحراء المشمسـة كان آخر ما تلفظ بـه لسـانه ـبـل آخر مـا 


\section{أساليب الاستـــراج في القصيـــة العربيــة}

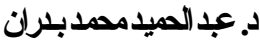

رطب به شفتيه اليابستين(أهم (1)

وقد أفلح الثاعر في توظيف الارتداد لإلقاء ضوء سريع على بعض ألوان المعاناة التي عاناها الجنود في ساحة القتال ، من أجل مقارنتها باللحظة الحاضـرة ، لكنـه طوى في هذا الارتـداد حكايـا كثيرة ، كانت تنزل بـردا وسـلاما على الصـدر ، حين تتقلهـه مـن جو مأسـاوي مهين ، إلى نقاء الطبيعة ، وصفاء الفطرة ، وتاريخ من الملفات الأسرية التي تروي الظمأ

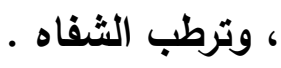

إن الارتداد هنـا قد وظف ببراعـة ؛ لأنـه حمل مثيراتهـه التي أسـهمت في بروزه وإحيائهه ، فالوجهه والضحكة والغمازتـان ، كلها مثيرات لعودة وجـه الأب وحكاياته في وجه ابنته وحديثها وضحكاتها . وممن آثر أن يبدأ قصيدته بالارتداد الثاعر كمال عبد الحليم ، حيث سلط الضوء من خلال الحكاية على رجل فقد ساقه في الحرب في قصيدة لـه بعنوان (رقصة الحرب) ، تخيل فيها أن شخصا ما قد دعا هذا العاجز إلى هي الرقص ، ومن ثم أتت إجابته عبارة عن سـؤال استهل به الثاعر قصيدته

قائـلا:(2)

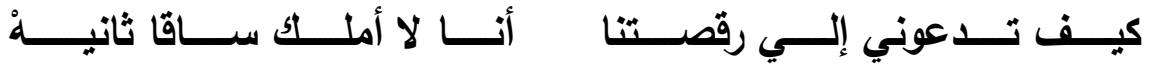

ثم أخذ الشاعر في سرد أحداث القصة في باقي الأبيات حيث يقول :

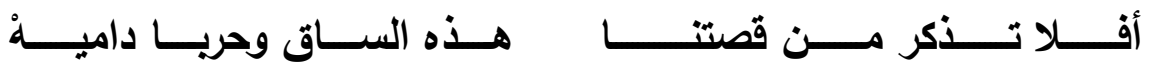

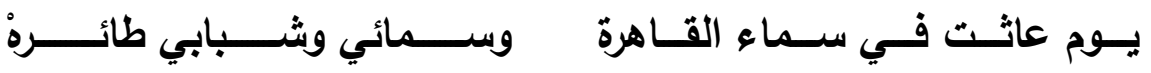

(1) عن بناء القصيدة العربية الحديثة صـ 211 . (2) الأعمـال الثـعرية الكاملة ـ كمـال عبد الحليم ـ المجلس الأعلى للثقافة . 2008 


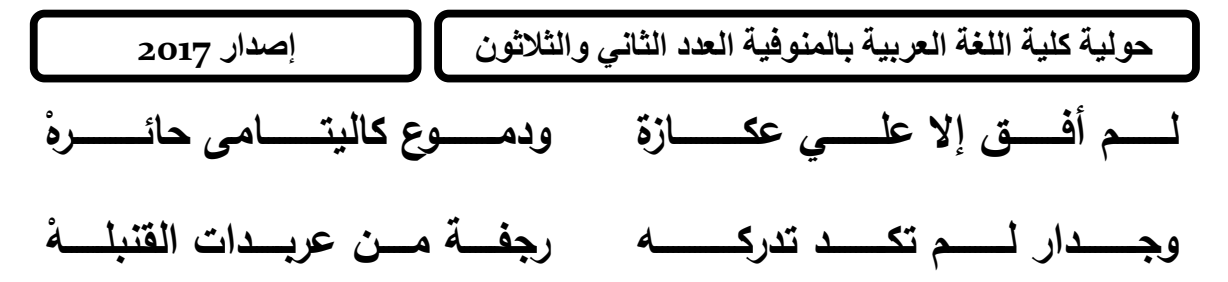

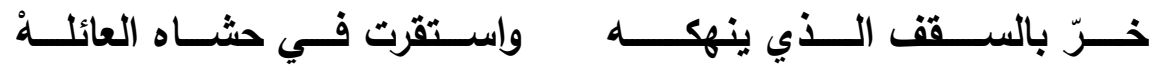

لقد وظف الثـاعر الارتداد في تصوير الواقع المرير الذي عاشته مصر وشعبها في سنوات الحرب المستمرة ، والهزائم المتوالية في 48 ، 56 ، 67 ، وكأن مجرد الدعوة إلى الرقص قد أعادت إلى ذاكرة المدعو كل

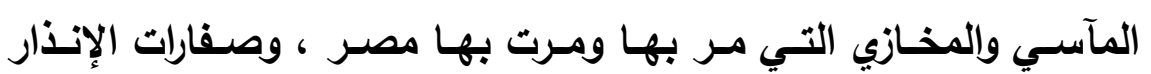
والغارات ، والملاجئ والمغارات التي كثيرا ما كانت قبورا للائذين بها.

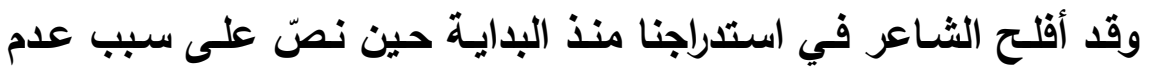

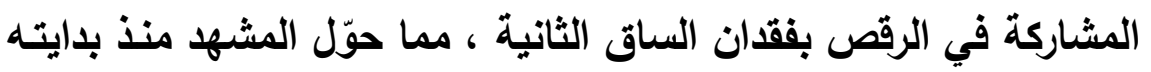

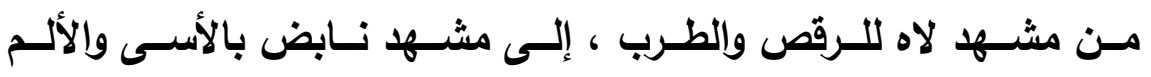
والتعاطف.

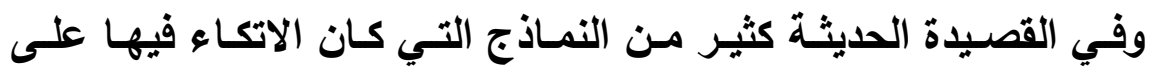
الدرامية في البناء مرشحا قويا لظهور الارتداد كأداة فنية من أدوات السرد الدئه في صدر قصيدة القصة ، على النحو الذي يبدو في قصيدة (أنا والمدينة)

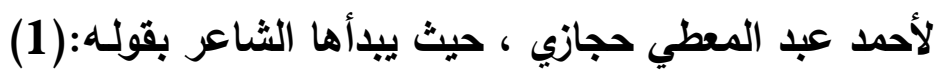
هذا أنا وهذه مدينتي ثم ما يلبس بعد هذا المشهد المختزل أن يشرع في سرد القصة المأسـاوية (1)ديو ان أحمد عبد المعطي حجازي ـ دار العودة بيروت ـ الثالثة 1982م

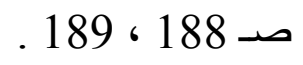


أساليب الاستـــراج في القصيـــة العربيــة

لد. عبدالحميدمحد بلران

، لطالب طرد من غرفته في منتصف الليل ، وكان يود لو يقضسي ليله سائرا في الثوارع ، أو تحت ضوء مصباح ، ولكن عسكري الدرج كثيرا مـا كان يقضسي على طموحسه في الاسـتراحة ، من خـلال أسـئلته التي تثير

$$
\begin{aligned}
& \text { الريبة ، حيث يقول حجازي : } \\
& \text { عند انتصاف الليل } \\
& \text { رحابة الميدان ، والجدران تل } \\
& \text { تبين ثم تختفي وراء تلّ } \\
& \text { وريقة في الريح دارت ، ثم حطت ، ثم } \\
& \text { ضاعت في الاروب ، } \\
& \text { ظل يذوب } \\
& \text { يمتد ظل } \\
& \text { وعين مصباح فضولي ممل } \\
& \text { دست على شعاعه لّما مررت } \\
& \text { وجاش وجداني بمقطع حزين } \\
& \text { بأتنه ، ثم سكت } \\
& \text { من أنت يا .. من أنت ؟ با } \\
& \text { الحارس الغبيّ لا يعي حكايتي } \\
& \text { لقد طردت اليوم } \\
& \text { من غرفتي } \\
& \text { وصرت ضائعا بلون اسم } \\
& \text { هذا أنا ، } \\
& \text { وهذه مدينتي ! }
\end{aligned}
$$

إن الجملـة التي آثر أن يتركنـا معها في النهايـة هي ذاتها التي قرعت 
أسماعنا في بلايتها ، لأنها تحمل لب القضية التي آمن بها الشـاعر في موقفه مـن المدينة القاسية ، تلك المدينة التي غدت بـدون قلب ، إنها نفس المدينة التي غدا فيها المهمش ورقة في مهب الريح . وقد أقلح حجازي في التركيز على كثير من عناصر القص ، كالمنولوج الاخلي في (هذا انا وهذه مدينتي) وتعدد الأصوات في (من أنت يـا ..) والغتاء الهامس في (وجاش وجداني بمقطع حزين .. بلأتها ثم سكت) ، والمكان (في رحابة الميدان والجدلان تل) ، والضوء في (ظل يذوب يمتد ظل) وهي صورة رائعة لاختزال مشه الظل أمام المصابيح وخلفها . 


$$
\text { بـ عبدالميدمحد بلران }
$$




\section{المبسحث اللخامس

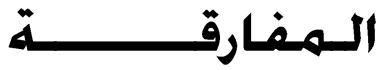

تعد المفارقة لونا من ألوان الاستدراج القني الأي يقوم أساسا على " رفض المعني الحرفي للكلام ، لصالح المعني الآخر ، أو بـالأحرى المعني الضد الأي لم يعبر عنه " (1) ، وإن كاتت في الأسـاس لونـا بلاغيا " لـ يعرفه بلغاء العرب علي هذا التحو من التحديد الحديث له ، وإن كانوا قد أحسوا بخصوصية الكلام الذي يراوغ ويهرب من تحديد المعني ، أو يقول شيئا ويعني شيئا آخر ، ومن هنا كان كلامهم عن التهكم والسخرية ولطائف

(2) (القول " (2) (2)

والمفارقة مـن شـأنها أن " تفتـرض مـن المخاطب ازدواجيـة الاسـتماع ، بمعني أن المخاطب يدرك في التعبير المنطوق معني عرفيا يكمن فيه من ناحية ، ومن ناحية أخري فإنه يدرك أن هذا المنطوق - في هذا السياق

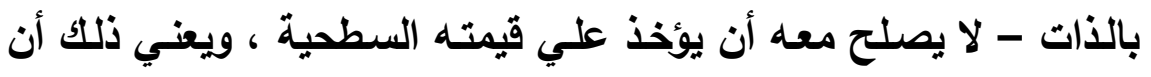
هذا المنطوق يرمي إلي معني آخر ، يحدده الموقف التبليغي ، وهو معني مناقض عادة لهذا المعني العرفي الحرفي"(2) ومن ثم يتم من خلال المفارقة في القصيدة تحريض المتلقي علي رفض المستوي الأول للنص ، طموحا إلي الوصول للمستوي الثاني ، لأن البعد الآخـر للنص هـو غايـة الثـاعر فـي المرتبـة الأولى ، أمـا البعد الأول

(1) المفارقة ـ نبيلة إبر اهيم ـ مجلة فصول ـ المجلد السـابع عدد 3 / 4 صــ

(2) المفارقة القرآنية د / محمد العبد ـ دار الفكر العربي ، الأولي 1994 صـ 


\section{أساليب الاستـــراج في القصيـــة العربيــة}

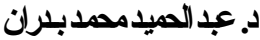

المسطح فهو مجرد استدراج للمتلقي من أجل التورط في الفعل القرائي والتفكيري في آن ، وعلى هذا النحو تبدو لنا قصسيدة (تكوينـات ليست جمالية) (1) للاكتور محمد أحمد العزب من القصائد الاستدراجية الجيدة القائمـة على المفارقة ، فقي أحد مقاطعها يلبس الثـاعر ثُب قديس مرتش ، ليبين الوجه الآخر الأي لا يُرى للقديس ، حيث يظهر من خلال هذا الوجه كيف يستحيل الدين تجارة ، على يد الذين يتقلدون المناصب دون أن يكونـوا مـؤهلين لتقلدها ، وكيف يطمـع رجـال الدين في الدين ، وكيف يقتعون العوام بفكرهم المغلوط ، مستظلين جهلهم بأصول الدين ، حيث يقول الشاعر على لسان هذا القديس : أبارككم

وأمستح شعركم يا أيها الأيتام أبادلكم بزيت الدار ألف مسافة في جنة الأحلام ... طريق الرب مفروش بجوع القلب وأنتم للقناء علي طريث الصلب إماء أنتم للجلب عبيد أنتم للسلب شياه أنتم للحلب

طريق الرب مفروش بأن جوعوا

(1) الأعمال الثعرية الكاملة د / محمد أحمد العزب ـ الطبعة الأولى 1995 م صـ353 ، 354 


$$
\text { وطويي للجياع علي طريق الرب . }
$$

طويي للعطاش إلي ينابيع من الأمثال .

إن مجرد بلء المقطع بالمباركة ومسح رأس اليتيم كفيل بأن يصنع تنويما عقديا لمن بشاهد هذا الصنيع الديني ، مهما بدا منه بعد ذلك ، فالمبادلة بزيت الدار لا يعدم المستدرِج أن يعللها بجزاء الصدقة في الآخرة ، والجوع المتوقع يمكن أن يعلله بمحاولة التشبه بالمسيح عليه السـلام في رحلته القاسية ، ومن ثم يأتي دور تكريس الدفقات الخداعية ، طالما أن الشاعر

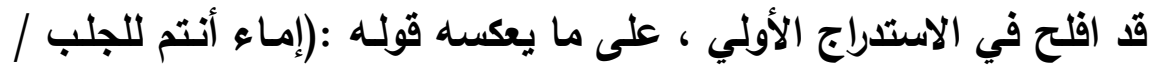
عبيد أنتم للسلب / شياه أنتم للحلب)؛ لأن الغاية الكبرى قد خطها الثـاعر في نهاية المقطع ، حيث الجنة والنعيم في قوله: طريق الرب مفروش بأن جوعوا وطويي للجياع علي طريق الرب . طويي للعطاش إلي ينابيع من الأمثال •

ومن ذلك أيضـا مـا نجده في قصيدة (السيرة الأتية لسياف عريسي)(1) لنزار قباني ، حيث يتقنع الثـاعر بقناع سياف السلطة ، الذي يتظاهر بالبراءة ، لارجة جعله يقرر الاعتزال حيث يقول : أيَّها الناس:

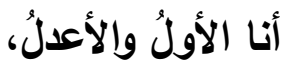
والأجملُ من بين جميع الحاكمينْ

(1) الأعمال السياسية الكاملة، نزار قباني، الجزء السادس، منشور ات نزار

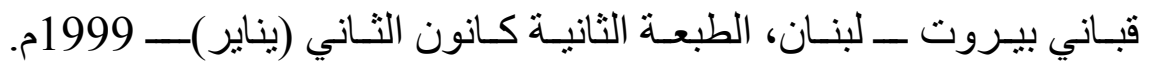
ص272 n (273، 273. 


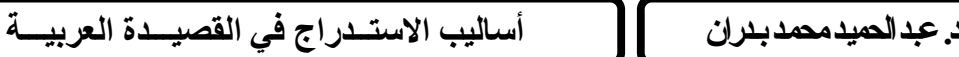

وأنا بلرُ الاجى، ويياضُ الياسمينْ ..

وأنا مخترعُ المشنقةِّة الأولى،

وخيرُ المرسلين..

كلما فكرتُ أن أعتزلَ السلطةَّ،

ينهاني ضميري . .

من ترى يحكم بعدى هؤلاء الطيبين؟

من سيشفى بعدى

الأعرج،

والأبرص، - الأحك،

والأعمى..

ومن يحيى عظام الميتين؟

إن المفارقة الحقيقية قد بدأت بعزم السياف على الاعتزال ، ولكن النهايـة قـ كثفت لنا كيف أفلح الثـاعر في استدراجنا لنقر معه في النهايـة كمـا قرر السياف أنه لا يصلح إلا السيف ، طالما كانت هناك طيبة وسـاجة ، تقرر معها أن السيف هو الدواء النـاجع الذي يشفي الأعرج والأبرص والأعمى ، بل يحيي العظام وهي رميم ، ليس بإذن الله كما فعل المسيح • عيسى بن مريم وقد تأتي المفارقة في انزياح (1) الدلالـة التراثية للنص وتحميله بدلالات

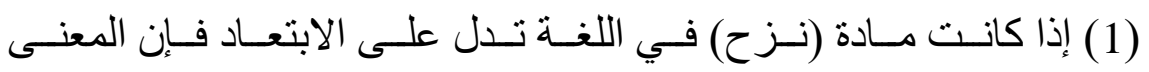

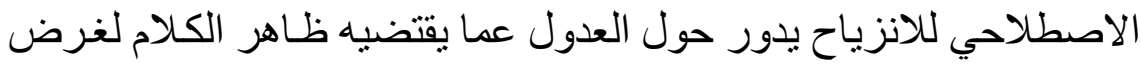

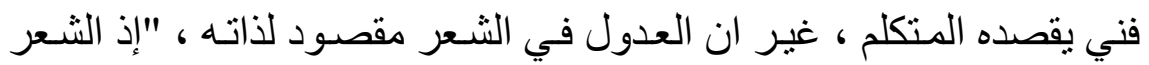

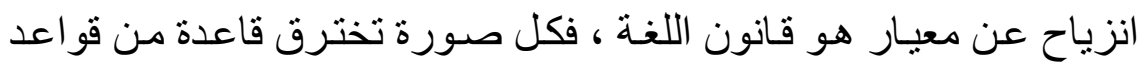

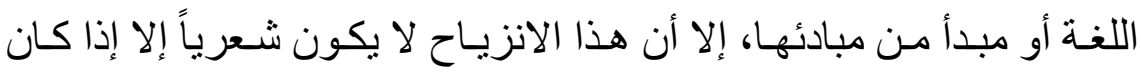


أخرى معاصرة ، كما فعل نزار قباني حين وجد ضالته الفتية في قناع ديك الجن الأي يعبر من خلاله عن عواطقه تجاه النساء ، وذلك في قصيدته (ديك الجن الامشقي) التي عبّر فيها عن مشـاعره هو ، لا عن مشـاعر ديك الجن ، مـع أن الشـاعر في قصيدة القناع كالروائي ، ليست لـه أنـاه الخاصة ، بل هو مضطر أن يستخدم ضمير المتكلم لياخلَ في وهم القارئ أن العمل القني حقيقي ، ولكن الشاعر قد تبنى فكرة أنسه عاشتق مخدوع ، وأنـه قتل حبيبته في حالة دفاع عن النفس ، لأنها بخيانتها لـه دمرت كرامته فثار لنفسه قائيلا : (1)

محكوماً بقانون يجعله مختلفاً عن غير المعقول" ، إذ إنّهـهـمح لهذا المبدع

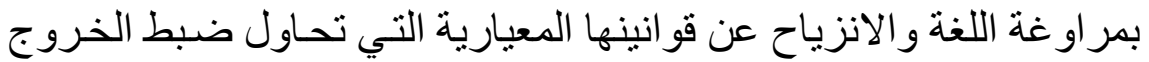

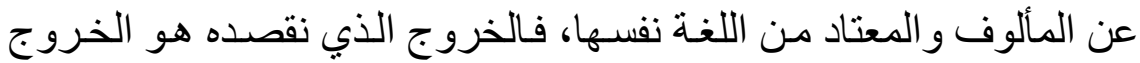

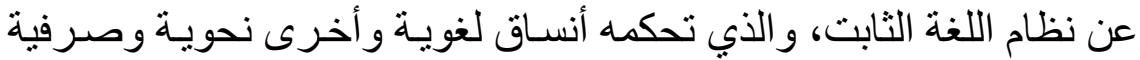

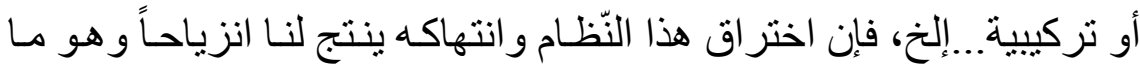
يكسب النّص جماليته و الشعرية موضو عها الحقيقي ـ ينظر الأسلوبية الرؤية

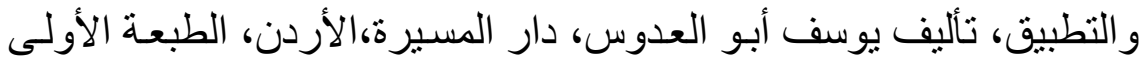

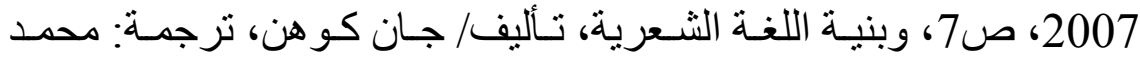
الولي ومحمد العمري، دار توبقال للنشر - المغرب الطبعة الأولى - 1986

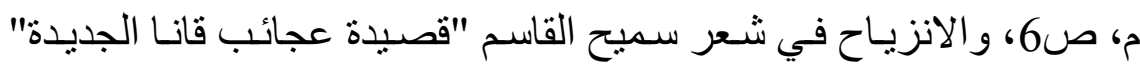

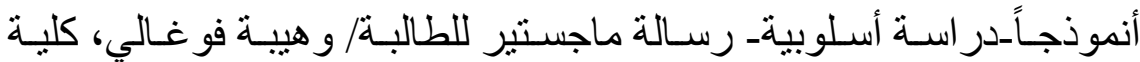

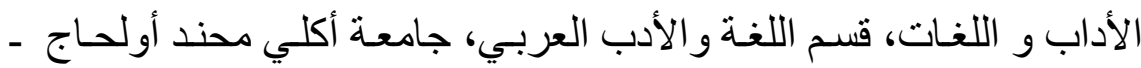

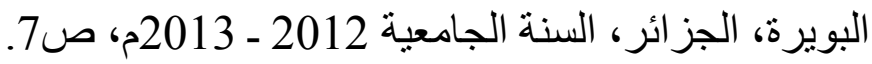
(1) ينظر : مجلة الموقف الأدبي ـ تصدر عن اتحاد الكتاب العرب بدمشق -

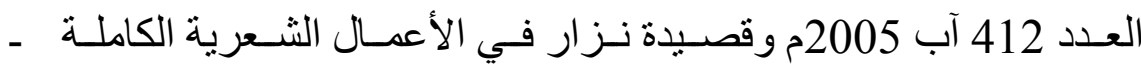

$$
\text { منشور ات نزار قباني الطبعة } 13 \text {-1993 جـ 1/ } 549 \text { ، } 550 \text { ـ } 550 .
$$




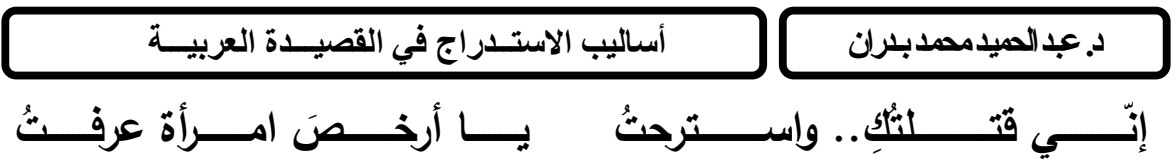

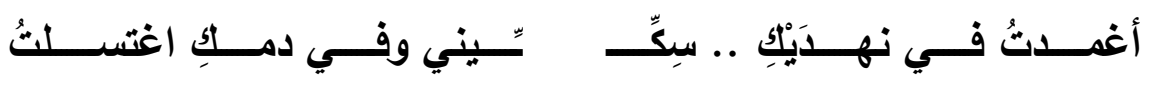

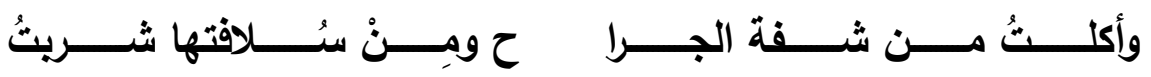

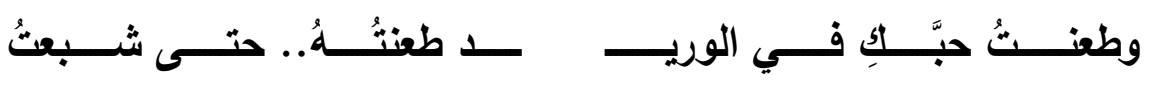

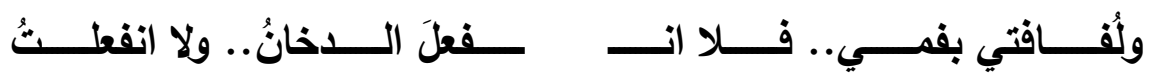

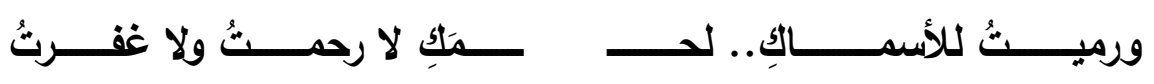

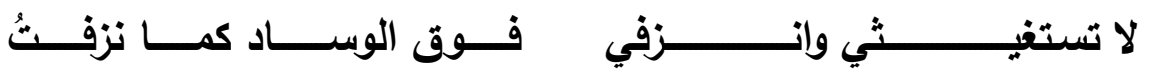

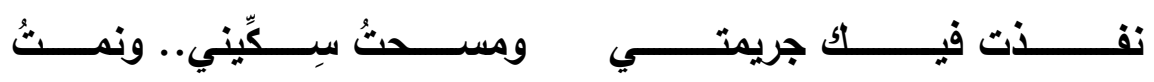
أمـا ديك الجن فلم يفعل ذلك ، فقد ظل يحبها ويرثيها بأفضل مـا قيل في الحب ، وهو الأي قتلها حتى قبل أن يعلم أنها مظلومـة ، وأن مـا حدث قـ

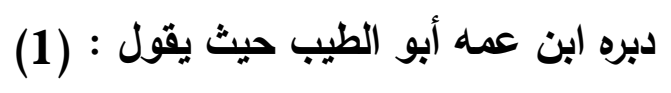

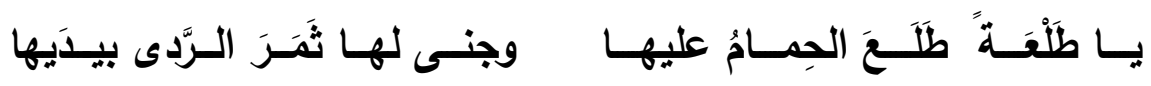

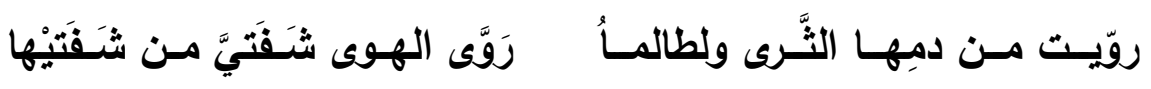

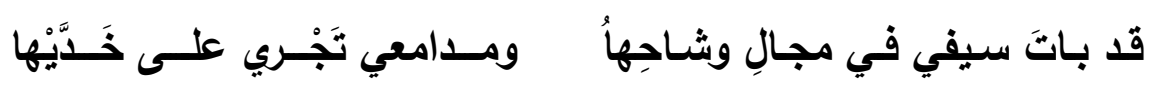

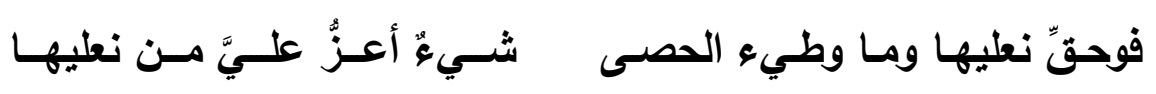
لكن نزار رغم كل هذا الإصرار على الانتقام ، ومفارقة الدلالة التراثيـة لقصـة ديك الجن ـ أصرَّ أن يستدرجنا ليعود في النهاية الى مثل مـا فعل ديك الجن

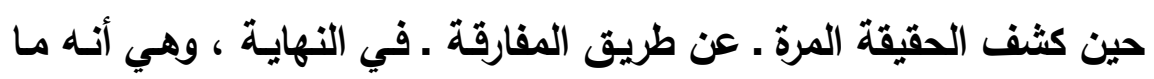

(1) ديوان ديك الجن الحمصي عبد السلام بن رغبان تحقيق / مظهر الحجي ـ منشور ات اتحاد الكتاب العرب ـ دمشق دئ 2004م صـ 288 ، 289. 


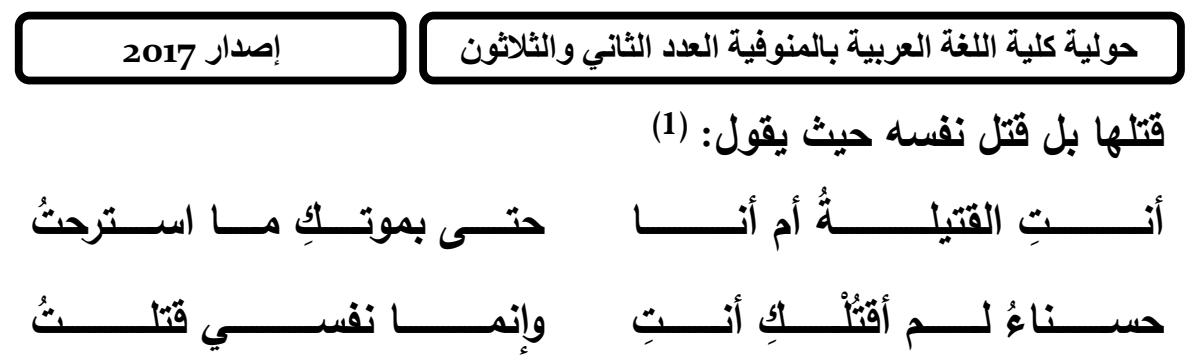

وقد توظف المفارقة في تصـوير المشـها حسب المبدأ الذي يـؤمن بـه الثاعر ، على النحو الذي يبدو في قصيدة (موت فلاح) (2) لصلاح عبد الصـبور ، فمع نهاية القصيدة التي وقف فيها الثـاعر من موت الفلاح في حقله موقفا ذا صبغة اشتراكية ، وجدناه يقول :

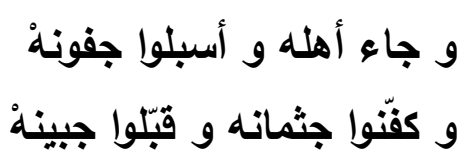
و غيّيوه في التراب في منخفض الرمال و حدّقا إلى الحقول في سكينه و أرسلوا تتهيدة قصيرة ... قصيرة ثمّ مضوا لرحلة يخوضها بقريتي الصغيرة

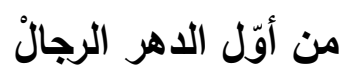
من أوّل الزمان حتّى الموت في الظهيرة

لقد تجسدت المفارقة في صورة أهل القريـة الآليين وقد تجمعوا لتجهيز المتوفى ودفنه بطريقة جافة ، حيث أسبلوا جفونـهُ ، و كفّوه و قبّلوه ، ثم هم غيّبوه في التراب ، دون أن نسـع صـرخة واحدة ، وإنمـا هـي تنهيــدة قصيرة قصيرة ، وكأن الشاعر يسخر من أهل هذه القريـة الذين اضطرتهم

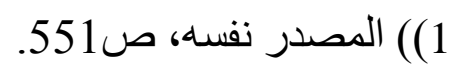
(2) ديو ان صلاح عبد الصبور ـ دار العودة بيروت ـ الأولى 1972م صـ 113، 114، 114 ـ 
ضغوط الحياة إلى دفن أحاسيسهم وكبث عواطقهم ، حيث استوى عندهم المـوت في الفراش مـع المـوت في الحقول في الظهيرة ، ويبين مفردات الحيـاة التي لامست جســـ كل يوم • كما تأتي المفارقة من الضيق بالصفة ثم الإصرار عليها ، كما يبدو في قول بعض الشعراء : (الوافز) (1)

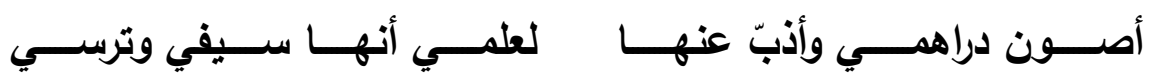

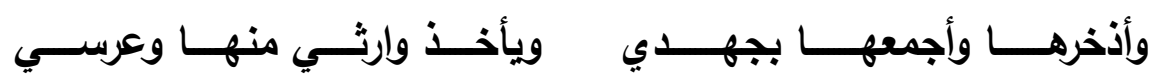

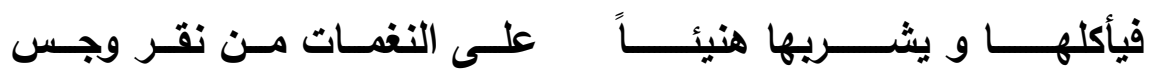

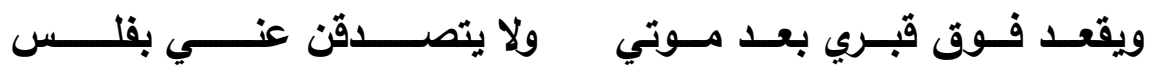
أحسب إلـي مـن قصــدي عظيمـاً كبيـراً أصــله مـن عبــ شــس أمــــ إليـــه كفـــي مســتميحا وأصــبح عبـــ خدمتــه وأمســي ويتركنـــي أجــر الرجـلـل منـــي وقـد صـارت كنفس الكلب نفسـي لقد أوهمنا الثاعر تمرده على خصلة جمع المال في بداية القصيدة ؛ لأن الـوارث لن يتصدق بفلس منهـا ، ولكنـه صدمنا في النهايـة مـن خـلال مفارقة أرينا فيها رضاه عن مثٔل هذا الصنيع ، لأنسه أولى عنده من قصد

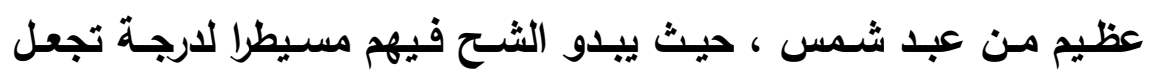
المعوز يحتقر نفسه إذا ما هم بطلب حاجة منهم .

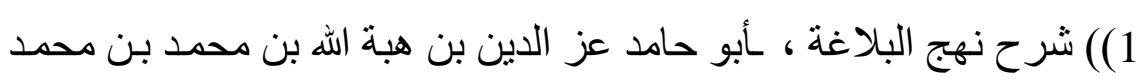

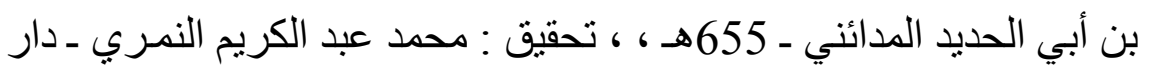

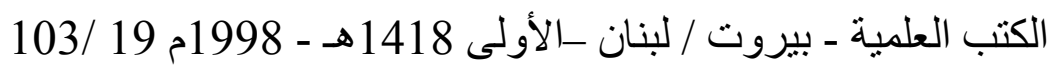


وقد تكون المفارقة (كاريكاتورية) تقوم على وصف مكونات الهيئة بصورة سـاخرة ، تقـوم على تعمـد مخالفـة الواقـع ، أو المقـاييس المعروفـة في الهيئة على النحو الذي يبدو في قول أعرابسي في امسرأة تزوجها، وقد

خطبها شابة طرية ودستوا إليه عجوزا:

عجــوز ترجّــي أن تكـون فتيّـة وقد نحل الجنبـان وإحدودب الظّهر تـدسّ إلسى العطّار سـلعة أهلهـا وهل يصلح العطـار مـا أفسد الدهر

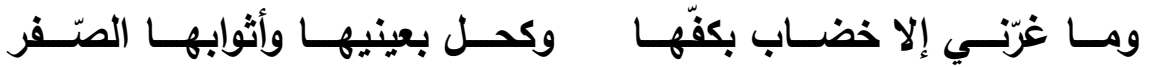

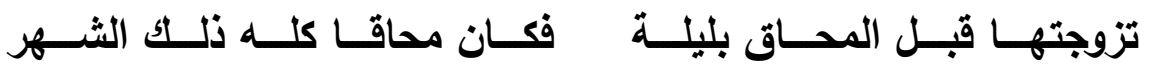
وقوله فيها أيضا : لها جسم برغوث وسـاقا بعوضـة ووجـه كوجـه القـرد بـل هـو أقبح وتبـرق عيناهــا إذا مــا رأيتهــا وتعبس في وجـه الضّجيع وتكلـح لها مضحك كالحشّ تحسب أنها إذا ضـكت في أوجـه القوم تسـلح

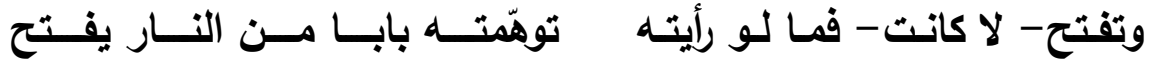
إذا عاين الشيطان صورة وجهها تعوّذذ منهـا حين يمسـي ويصسبح إن الهيئة التي وصفها الأعرابي كاريكاتورية ساخرة ، يستحيل وجودها في عالم البشر ، ولكن المفارقة ، أو قل الصدمة التي وقع فيها جعلته يضع كل الصفات والهيئات غير الجيدة في صورة امرأة ؛ لتخرج الصورة فظيعة

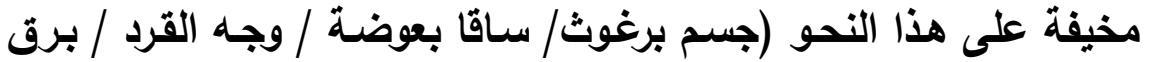
العينين / عبوس الوجه / ضحك كالسـلاح / فم كالنـار) ، لكنـه يستـرجنا بهذه الصور المفردة القبيحة ليصدمنا في نهايـة الأبيات بالمفارقة الكبرى والصورة المثلى للسخرية مع نهاية كل مقطّعة ، وهي كون الزوجة سببا 
أساليب الاستـــراج في القصيــدة العربيــة

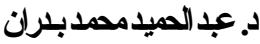

في تغيير سنن الكون ، وجعل الشهر محاقا كله ، ومفارقة تعوذ الشيطان نفسه من صورة وجهها ، وهو الكائن الذي استقرت صورته في الأذهان كمثل أعلى لقبح المنظر . وقد تبدو الصورة السـاخرة في المفارقة مصنوعة بإحكام من أجل التفنن في استخراج النوال ، على النحو الأي يبدو في وصف بشار بن برد لشـاة ضعيفة نحيلة أهلايت له ، حيث يقول : (المتقارب) (1)

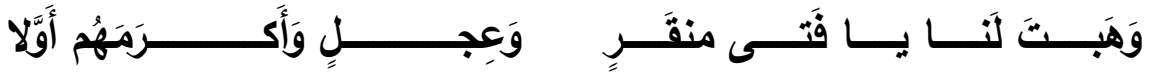

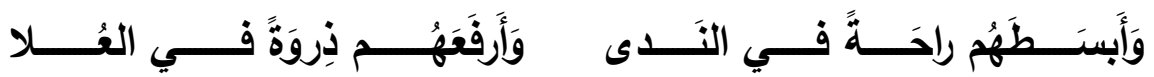

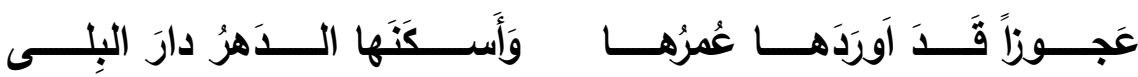

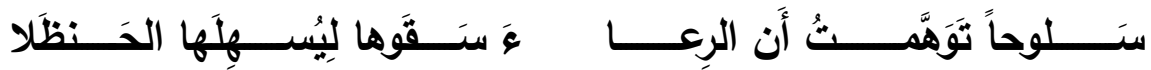

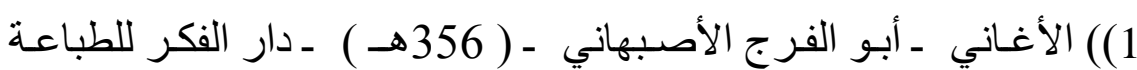

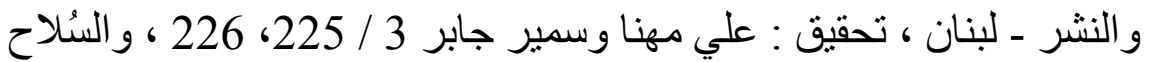

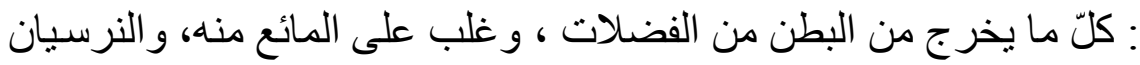

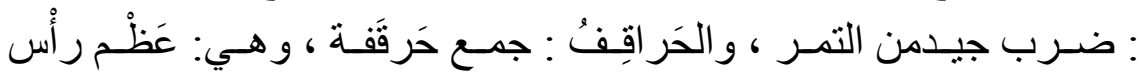
الورك، وسبب قصيدة بشار أنه كان بالبصرة فتى من بني منقر أمسه عجليـة

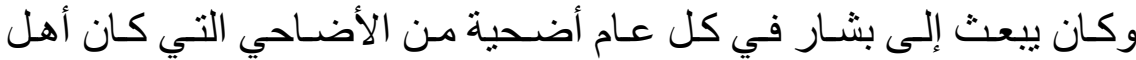

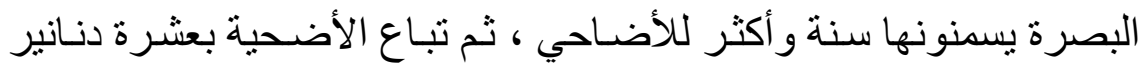

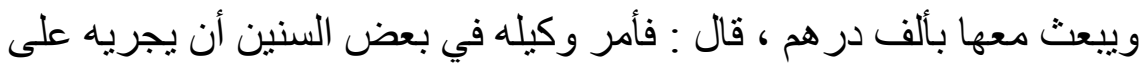

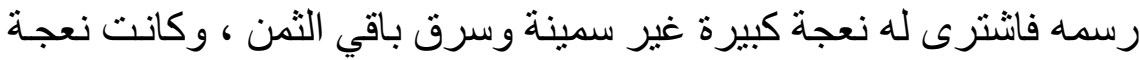

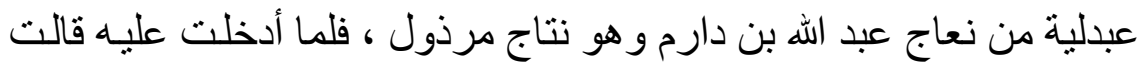

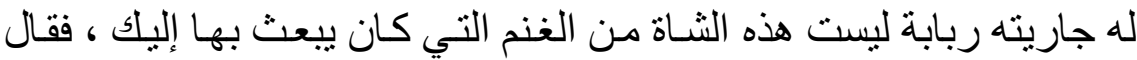

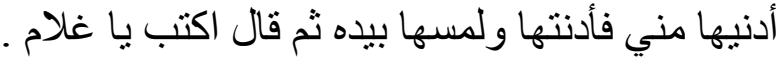




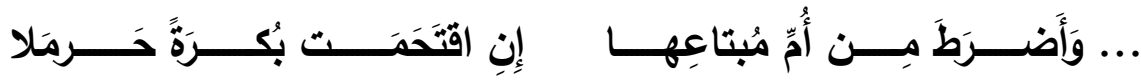

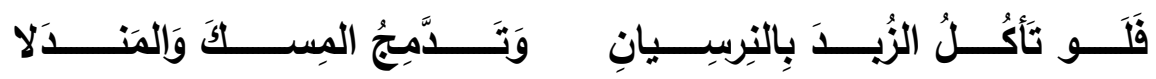

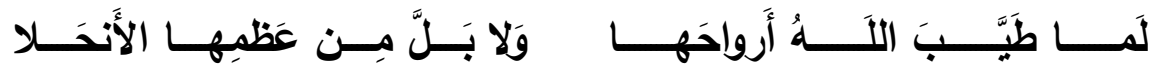

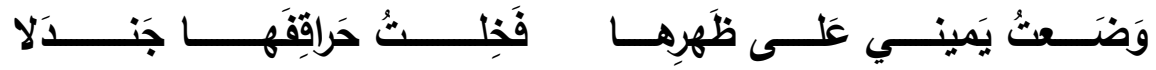

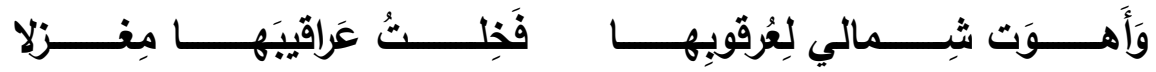

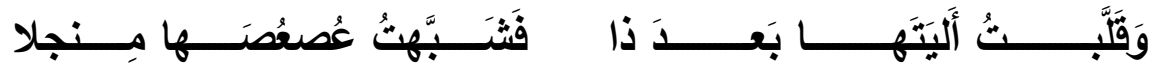

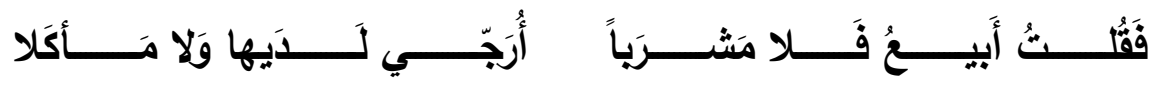

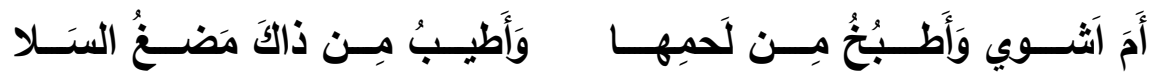

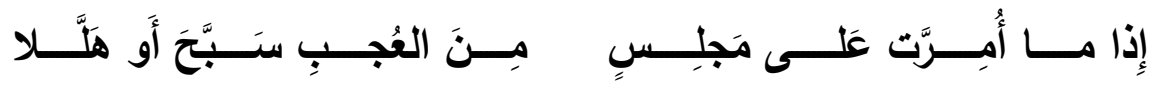

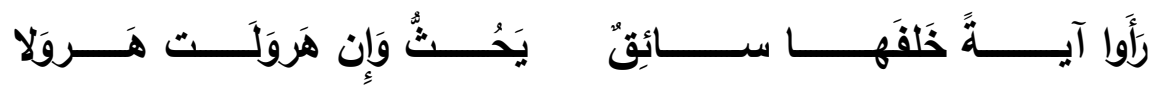

لقد رسم بشار صورة نادرة الوجود لشـاة جمعت كل الخصسال السيئة في شـياه الأرض ، بــاء مـن صـفاتها الخلقيـة ، فهي عجوز سـلوح ضـروط نحيلة ، وإنتهاء بالأثر النفسي الأي تركته في نفس المهداة لـه ، ونفس كل من رآها ، لارجة جعتهم يسبحون ويهللون تعجبا من هيئتها ، ليصل الأمر في النهاية إلى زهد المهدى له فيها.

إن المفارقة لا تكمن في السخرية من صورة الثاة بقدر ما تكمن في شدة الحاجهة وإلعوز الذين سلط عليهما الثـاعر الضوء في نهايـة القصيدة ، حيث أظهر أنه في أثد الاحتياج إلى الانتفاع بها ، في الوقت الذي هي فيه في حاجة إلى الرعاية والاهتمام ، ومن ثم أحس الشاعر أنها صارت 
أساليب الاستــــاج في القصيـــة العربيـــة

د. عبدالحميدمحد بلران

عبئـا ثقيلا عليـه ، وكأنها طقلـه الصـفير الذي يثقلـه بمتطلباتهـه ، ممـا استوجب الزهد فيها في قوله :

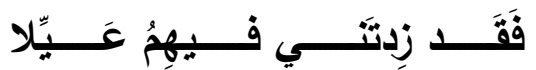

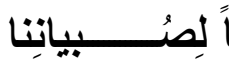

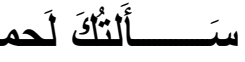

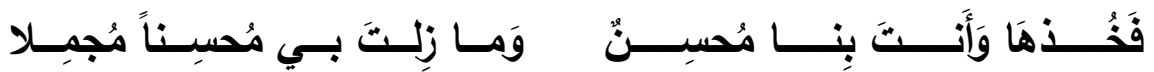
وق تظهر حدة المفارقة واضحة جلية ومكثفة في المقطعات(1) الثـعرية التي تعتمد على البيتين أو الثلاثة أبيات ، وفيها يصدم القارئ بلون شديا من ألوان السخرية التي تعري واقعا مغلوطا ، حتى لو كان دعابة ، على النحو الأي صنعه الحمدوني في معارضة أبيات عملها أَبُو حمْرَان السّلمِيّ في طيلسان له قد بلي ووهي فكان يقول : (2)

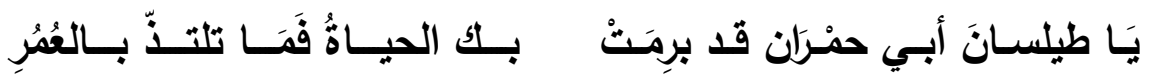

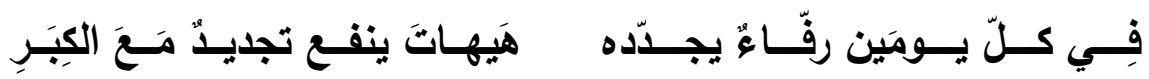

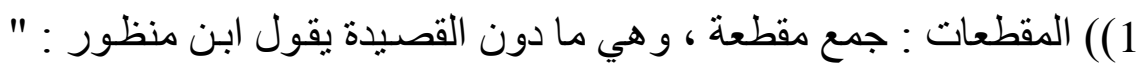

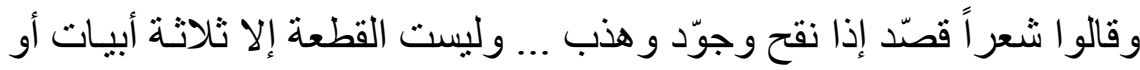

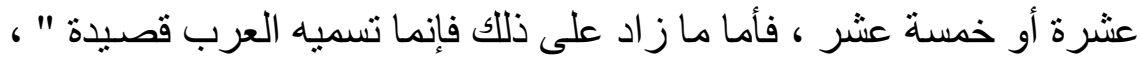

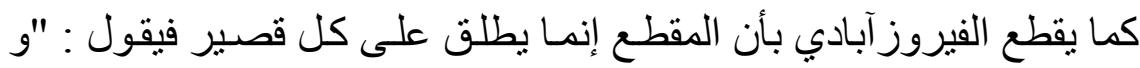

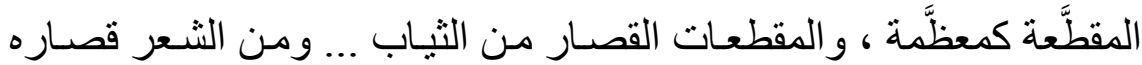

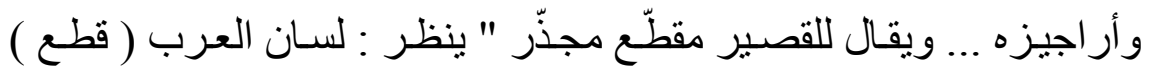
والقاموس المحيط : مجد الدين الفيروز آبادي ـ دار الحديث ـ ـ ( قطع ) . .

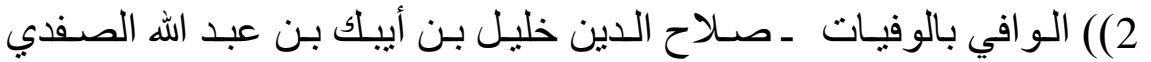

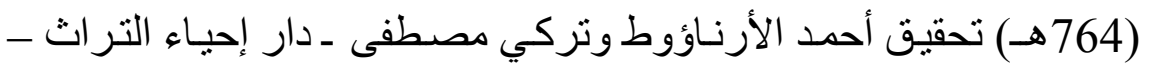

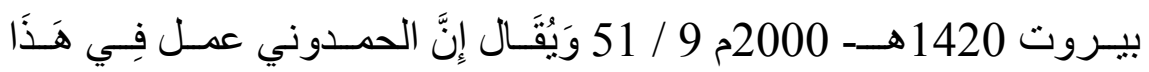
الطيلسان مِائَتي مَقْطُو ع فِي كل مَقْطُو ع معنى بديع . 


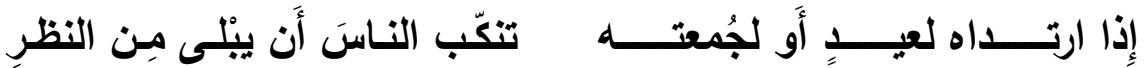
إن تناول الطيلسـان بهذه الطرافة تناول سـاخر ، ولكن التركيز مـ نهايـة المقطعة على أهم وأعمق صورة يظهر لنا كيف كان الشاعر بارعا وهو يقفنا على مدى رثاثة الطيلسان وعدم صلاحيته للبس ، من خلال الصورة في البيت الأخير ، إذ أجملت كل معاني الرثاثية في مفارقة جيدة ، جعلت عيون الناس تأنف من النظر إلى هذا الطيلسان ؛ لأنه لرثاثته يتأثر ويبلى • بمجرد النظر

ومن ذلك اللون من المفارقات التي يفلح التضمين الجيد فيها في إحداث الاهشة من ضم القرائن واللعب بالألفاظ ، توظيف بعض الشعراء آيات من القـران الكـريم ، يختمـون بهـا مقطعـاتهم ، باعتبارهـا المثل الأعلى في الفصاحة ، ليتحقق استدراج المتلقي إلى أفضل صورة يمكن لها أن تستقر في ذهنه ، على النحو الأي يبدو في قول الحمدوني في طيلسان أهداه لله أحمد بن حرب المهلبى : (مجزوء الكامل)(1)

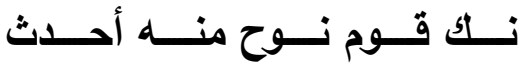

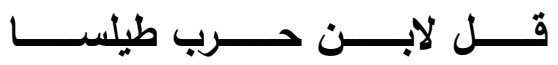
القـــرون ولــــم يـــزل عمّـن مضــى مـن قبـلـل يــورث (ٔفن

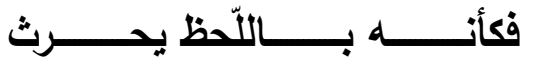

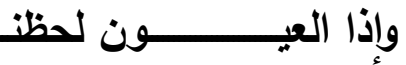

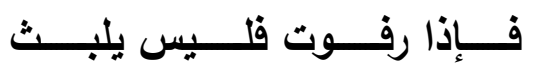

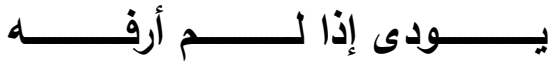

1) زهر الآداب وثمر الألباب ـ إبر اهيم بن علي بن تميم الأنصـاري، أبو إسحاق الحُصري القيرواني (453هـ) : دار الجيل، بيروت 2 / 591 ، 592 


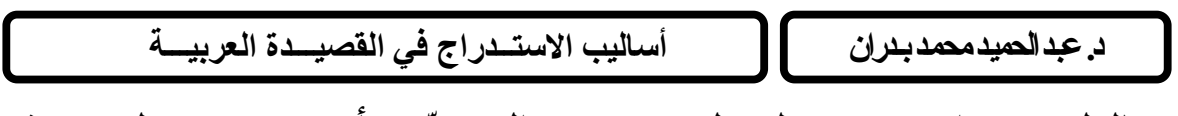

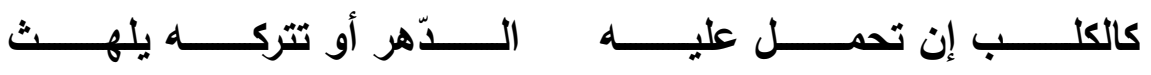

وَقَوَلهه فِيهِهِ أَيْضا: (الرمل) (1)

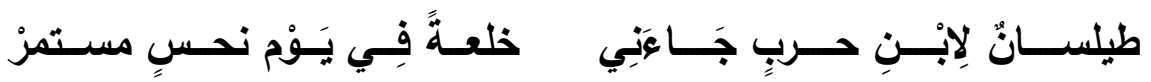

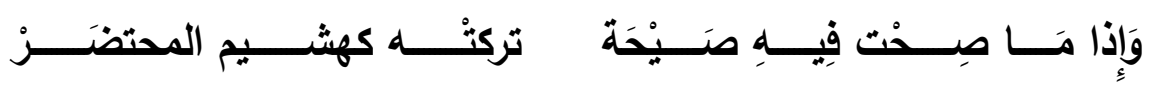

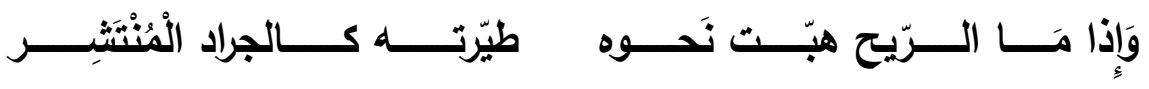

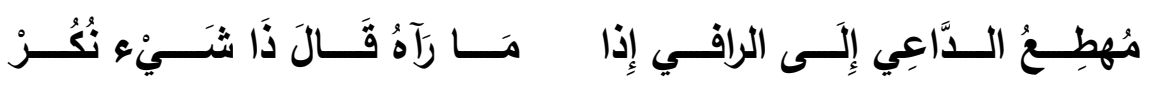

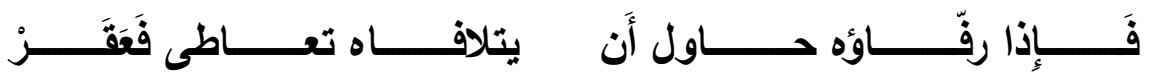

لقد طوف بنا الثـاعر في القصص القرآني من خـلال تضميناته الموحية التي أبرزت هشاشة طيلسانه ، وأنه لهشاشته ورثاثته كالكلب الذي يلهرث ، سواء حمل شيئا أم لم يحمل ، وقد انعكس موقف الثـاعر من طيلسـانه على اليوم الأي أهدي لـه فيه الطيلسـان ، فوصفه بيوم النحس المستمر الأي وصف به المولى عز وجل يوم عاد ، كما أن الطيلسان لفرط رقته يبلى من شدة الصوت ، حيث يتركه الصوت كهشيم المحتظر ، بما يوحي به الوصف في القرآن الكريم من هلاك وفنـاء ، كمـا أنـه يطير إذا داعبته الريـاح فيصير نتفا كالجراد المنتشر ، كما أن رفاءه في تأفف دائم من رويتهـ ؛ لإحساسـه بأنسه إذا أقدم على إصـلاحه فإنمـا يرتكب جرمـا عظيمـا مثل الأي صنعه عاقر الناقة (قار بن سالف) (2).

$$
\text { 1)) الو افي بالوفيات } 9 \text { / } 49 \text { ، } 50
$$

2)) قدار بن سالف عاقر ناقة صالح ـعليه السلام 


\section{الخاتمـــة}

أما بعد فقد خلص البحث في (أساليب الاستدراج في القصيدة العريية) إلى بعض النتائج نجملها فيما يأتي :

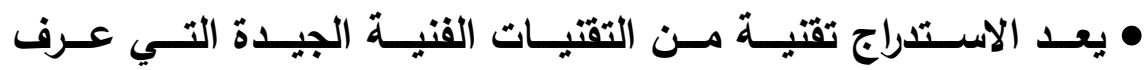
الثـاعر العربـي قيمتهـا ودورهـا فـي إحـداث يقظـة المخاطـب ، حيــ أخــ مسن الغنائيـة والقصصسية مــا جعلـه وسـيلة للغـوص فـي الغنائيـة دون أن يخضـــع لهـــا ، ويهـــيم بالقصصــية دون أن تفــرض عليـــهـ شـروطها ونمطيتها ، ومسن ثـم كانـت ملاحظـة الاسـتـراج في القصسيدة العربيـة ملاحظـة جــيرة بالاهتمــام والدراســة ، ويخاصــة أن الدراســات

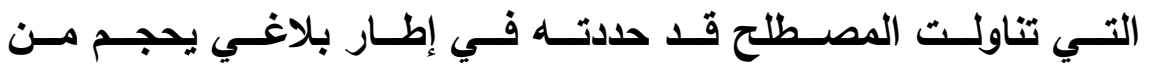
فضـاءاتهـ ، ويحصـره في كونـهـه قيمـة مـن القيم البلاغيـة التـي تنطـوي عليهـا الكتابـة الأدبيـة ، ولـيس وسـيلة فنيـة مسن وسـائل جذب القـارئ

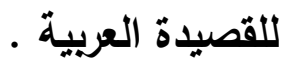

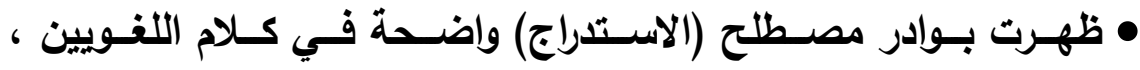

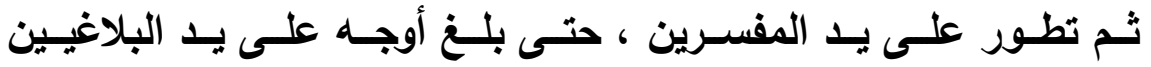
والنقـاد ، الــين لاحظـوا لجـوء بعـض الثـعراء إلـى أسـلوب الاسـتـراج رغبـة في القضـاء على الرتابـة التـي كـان المتلقـي يعيثـها مـع كثيـر مـن القصـائد النمطيـة ، وهـذا اللجـوء قـد أسـهم فـي التصـريح بوجـود

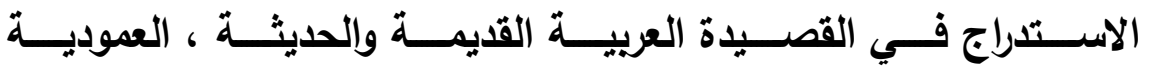
والمتحـررة مسن قيـود الشـكل الخليلـي ، ممـا أعطسى المصــلح ظهيـرا نقديا يستند إليه في مسيرته القتية .

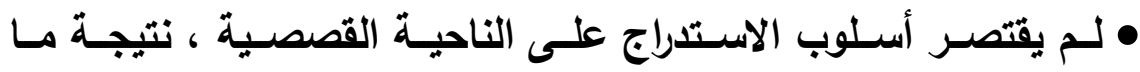




\section{أساليب الاستـــراج في القصيـــة العربيــة}

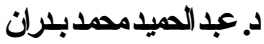

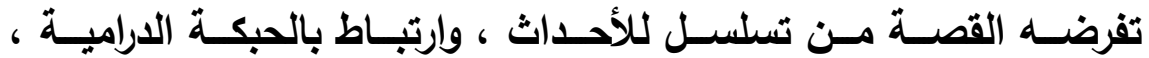
ويراعـة القـاص فـي اسـتدراج القـاريء بـوعي أو بـدون وعسي ، وإنمــا

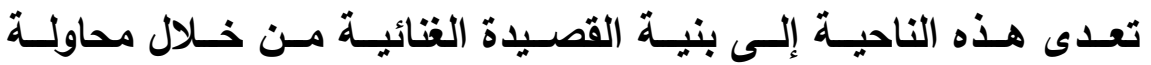
الربط بين أجزائها التي قد تبـو بعيدة للنظر الـوهلي ، ولعـل هذا هـو مـا جعل كل الإثـارات النقديـة تصـب في هـا الجانـب ، وتهتم برصــ أسسس الاســــاج التـي تخـص بنيـة القصسيدة العربيـة ، في مقـمتها

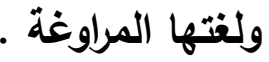

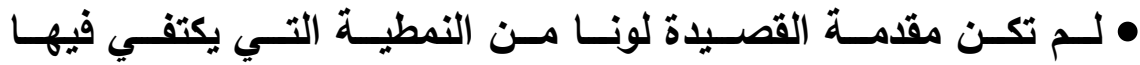
الشـاعر بـالحرص علـى (حسن الـتخلص) ، وإنمــا كثيـرا مـا جـاعت مرتبطـة بهـدف القصسيدة ، ومرشـحة مــا تحتويسه مـن مضــامين ، بـل مفتاحسا مـن مفـاتيح اسـتدراج القـارئ للإيمـان بمـا تصـبو إليـه القصـيلة وتأكيده .

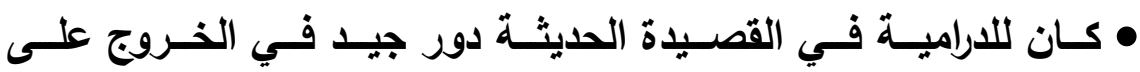
كثيـر مسن النمطيـة فـي القصسيدة الحديثـة ، حيـث عملـت على جعل المتلقـي فـي حالـة اسـتبطان مسـتمر ، بمــا هـو محكـوم فـي قـراءة النص بقـراءة الغـابر في الآنـي ، والغائب في المـتكلم ، وكل ذلــ قـ أسـهم فـي حركيـة القصسيدة العربيـة ، وسـاعد على تطورهـا مسن خـلال تقتيتي الارتداد والنهاية المفاجئة . 


\section{هراجع البحث}

• إرشـاد العقل السليم إلى مزايـا القرآن الكريم ، أبي السعود محمـ بن محمد العمادي ــدار إحياء التراث العربي - بيروت.

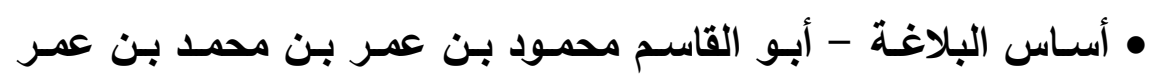
الخوارزمي الزمخشري ـ دار الفكر - 1979م .

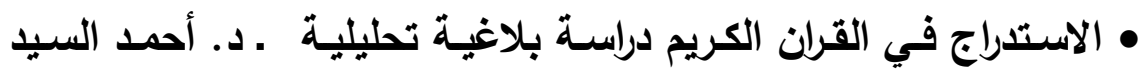
طلحة داود ـ مطبعة الثروق بالراهبين ـ الطبعة الأولى 2004م ـ

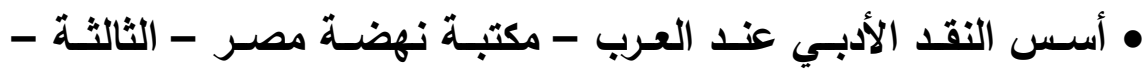
1964 • الأسلويية الروئية والتطبيت • يوسف أبو العدوس، دار المسيرة،الأردن .

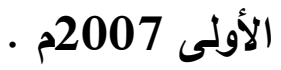

• الأعمال السياسية الكاملة، نزار قباني، الجزء السـادس، منشورات نزار قباني بيروت ـ لبنان، الطبعة الثانية كانون الثاني (يناير)ـ 1999م. • الأعمال الشعرية الكاملـة ـ أمل دنقل ـ مكتبـة مدبولي ـ القاهرة ـ الثالثة 1987 • الأعمال الشعرية الكاملة كمـال عبد الطليم ـ المجلس الأعلى للثقافة $\mathbf{2 0 0 8}$ • الأعمال الشعرية الكاملة ـ منشورات نزار قباني الطبعة 13 . 1993م

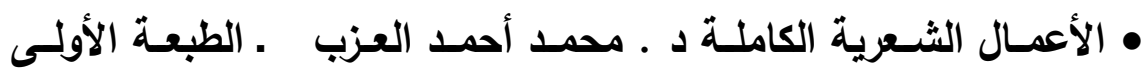
$\mathbf{1 9 9 5}$

• الأعمال الكاملة ـ سعدى يوسف ـ الجزء الخامس ديوان (حفيد امريع القيس) ـ منشورات الجمل ـ بيروث 2014 م . 
أساليب الاستــــاج في القصيــــة العربيــة

لد عبدالحميامحمدبران

• الأغاني ـ أبو الفرج الأصبهاني ـ (356هـ) ـ دار الفكر للطباعة والنشر

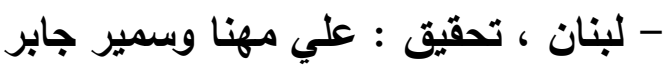

• الأقصى القريب في علم البيان للتنوخي ـ السعادة ـ الأولى 1986م • الانزياح في شعر سميح القاسم "قصيدة عجائب قانا الجديدة" أنموذجاًدراسـة أسـلويية- وهيبـة فوغـالي، رسـالة ماجسـتير في كليـة الأداب و اللغات، قسم اللغة والأدب العربي، جامعة أكلي محند أولحساج ـ البويرة، الجزائر، السنة الجامعية 2012 ـ 2013م

• بناء الرواية د ـ عبد الفتاح عثمان ـ مكتبة الشباب 1982 م

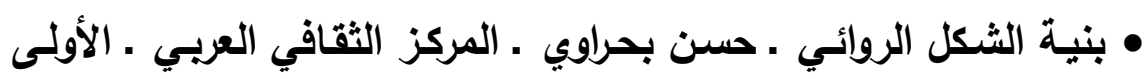
- 1990

• بنية اللغة الشعرية . جان كوهن، ترجمـة محمد الولي ومحمد العمري . دار تويقال للنشر - المغرب الطبعة الأولى - 1986 م. • تاج العروس من جواهر القاموس ـ محمد مرتضسى الحسيني الزبيدي ، تحقيق مجموعة من المحققين ـ دار الهداية • التحرير والتنوير - محمد الطاهر بن عاشور ـ الدار التونسية للنشر 1984 • تفسير البحر المحيط ـ محمد بن يوسف الثهير بأبي حيان الأندلسي .

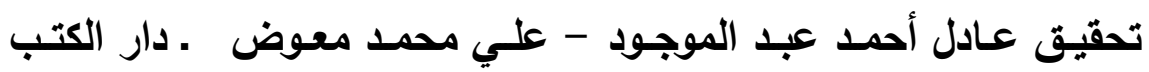
العلمية - بيروت ـ الأولى 1422هـ - 2001م • تفسير البغوي ـ معالم التنزيل في تفسير القرآن ـ أبو محمد الحسبن بن مسعود بن محمد بن الفراء البغوي الثـافعي (ت510هـ) ـ تحقيق عبد الرزاق المهدي ــدار إحياء التراث العريسي سبيروت ـ الأولى ، 1420 هـ

$.255 / 2$ 
• تفسير البيضاوي ـ ناصر الدين أبو الخير عبد الله بن عمر بن محمد

$$
\text { الشيرازي البيضاوي ـ دار الفكر - بيروت }
$$

• تفسير القرآن / اختصار النكت للماوردي ـ الإمام عز الدين عبد العزيز بن عبد السلام السلمي الامشقي الشافعي ـ تحقيق ـ د عبد الله بن إبراهيم الوهبي ـ دار ابن حزم - بيروث - الأولى 1416هـ/ 1996م • تهذيب اللفة ـ أبو منصور محمد بن أحمد الأزهري ـتحقيق محمد اهدي عوض مرعب ـ دار إحياء التراث العربي - بيروث - الأولى 2001م • ثمار القلوب في المضاف والمنسوب . عبد الملك بن محمد بن إسماعيل أبو منصور الثعالبي (ت429هـ) ـ دار المعارف - القاهرة صد 659. • جامع البيان عن تأويل آي القرآن ـ محمد بن جرير بن بزيل بن خالد

$$
\text { الطبري ـ دار الفكر - بيروت - } 1405 \text { هـ }
$$

• الجامع الكبير في صناعة المنظوم من الكلام والمنثور ـ ضياء الدين نصر الله بن محمد الثيباني، أبو الفتح ، المعروف بابن الأثير الكاتب . تحقيق مصطفى جواد ـ مطبعة المجمع العلمي ـ 1375هـ • جوهر الكنز ـ تلخيص كنز البراعة في أدوات ذوي البراعة ـ نجم الدين أحمد بن إسماعيل بن الأثير الحلبي (737هـ) تحقيق ـ محمد زغلول سلام

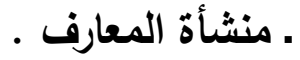
• خزانـة الأدب وغايـة الأرب ـ ابن حجـة الحموي (أبو بكر بن علي) شرح عصام شعيتو - دار الهلال - بيروت - الأولى 1987م • • خطاب الحكاية ـ جيرار جنيت، ترجمة محمد معتصم وعبد الجليل الأزدي وعمر حلي ـ المجلس الأعلى للثقافة ـ الثانية 1997م • ديوان أبي ماضي ـ دار العودة 1996م • ديوان أحمد عبد المعطي حجازي ــدار العودة بيروت ـ الثالثة 1982م 


\section{أساليب الاستـــراج في القصيـــة العربيــة}

• ديوان الأعشى الكبير تحقيق د. محمود إبراهيم محمد الرضواني - وزارة الثقافة والقنون والتراث بقطر ـ الأولى 2010م • ديوان البارودي ـ ضبط ـ علي الجارم ومحمد شفيق معروف ـ المطبعة الأميرية ، 1948م

• ديوان النابغة الذبياني تحقيق / حمدو طماس ـ دار المعرفة بيروت . الثانية 2005م • ديوان امريء القيس ـ دار صـادر • بيروت • ديـوان ديـك الجن الحمصسي عبد السـلام بـن رغبـان تحقيـق / مظهر الحجي ـ منشورات اتحاد الكتاب العرب ـ دمشث 2004م • ديوان صلاح عبد الصبور ـ دار العودة بيروت ـ الأولى 1972م • ديوان طرفة بن العبد ـ شرح مهدي محمد ناصر الدين ـ دار الكتب العلمية ـ الثانية 2002م • ديوان عمر أبو ريثة دار العودة ـ بيروت 1988م. • ديوان عمر بن أبي ريبعة ـ تحقيق د. فايز محمد ـ دار الكتاب العربي . الثانية 1996م

• روح المعاني في تفسير القرآن العظيم والسبع المثاني ـ شهاب الدين السيد محمود الألوسي البغدادي ـ دار إحياء التراث العربي - بيروت

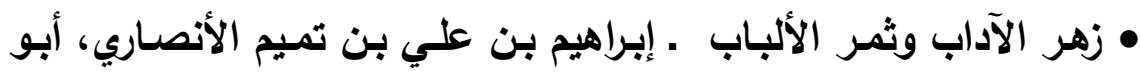

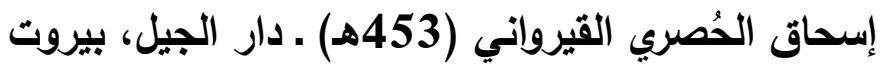

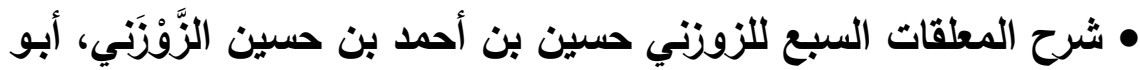
عبد الله (ت486هـ) ـ دار احياء التراث العربي ـ الأولى 1423هـ 2002 • شرح ديوان كعب بن زهير - صنعة أبي سعيد السكري - دار ا لكتب 


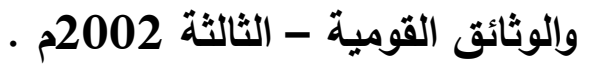

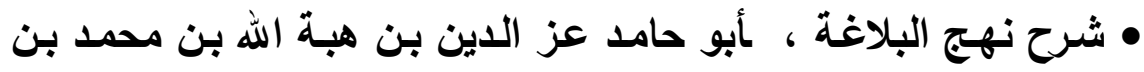

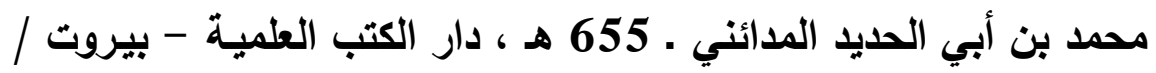

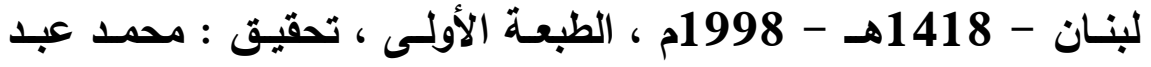

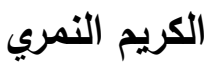

• شعر مروان بن أبي حفصة ـ تحقيق / حسين عطوان ـ دار المعارف ، الثالثة 1982م • الثـعر والثـعراء لابـن قتيبـة - تحقيـق/ أحمــ شـاكر - دار المعـارف 1982 • الصحاح الجوهري (إسـاعيل بن حمـاد) تحقيق أحمد عبد الغفور

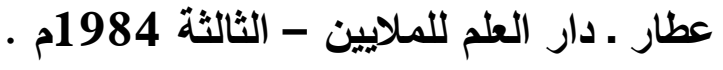
• الطراز ـ يحي بن حمزة العلوي ـ تحقيق / محمد عبد السلام شـاهين .

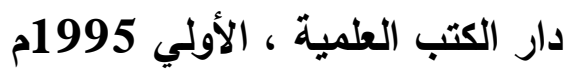
• طيف الخيال ـ الثريف المرتضى ـ تحقيق حسن كامل الصيرفي ـ الهيئة

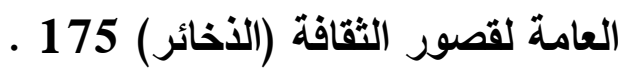
• العمدة ـ ابن رشيق القيرواني - تحقيق ـ محمد محي الدين عبد الحميد - دار الجيل - الخامسة 1981م . • عن بناء القصيدة العربية الحليثة ـ د. على عشري زايد ـ مكتبة ابن النئ

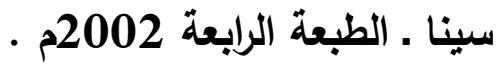

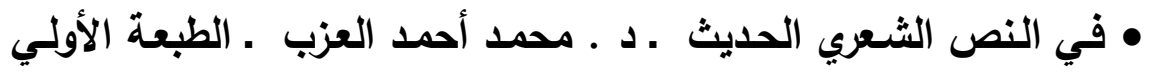
2000 • في مملكة الثعر ـ أحمد عبد المعطي حجازي ـ الهيئة المصرية العامـة لبكتاب 1999م 


\section{أساليب الاستـــراج في القصيـــة العربيــة}

د. عبد الحميدمحد بلران

• القاموس المحيط ـ مجد الدين الفيروزآبادي - دار الحديث .

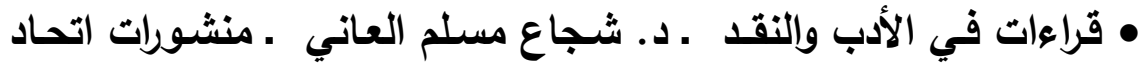

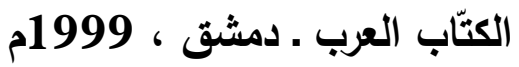
• الكثـاف عن حقائق التزيل وعيون الأقاويل في وجوه التأويل ـأبو القاسم محمود بن عمر الزمخشري الخوارزمي ـتحقيق .عبد الرزاق المهدي ـ دار إحياء التراث العربي - بيروت • لسان العرب ـ محمد بن مكرم بن على، أبو الفضل، جمال الدين ابن منظور الأنصاري الرويفعى الإفريقى (711هـ) دار صادر ـ بيروت ـ الثالثة \$414 -

• المثل السائر في أدب الكاتب والثاعر ـ ضياء الدين نصر الله بن محمد الشيباني، أبو القتح ، المعروف بابن الأثير الكاتب (ت 637هـ) ـ تحقيق أحمد الحوفي، بدوي طبانة ـ دار نهضـة مصر للطباعة والنشر والتوزيـع . القاهرة • مجلة الموقف الأدبي - تصدر عن اتحاد الكتاب العرب بامشق - العدد 412 • مجلـة فصـول - مجلـ 7 عـدد(3 ، 4) (إبريـل - سـبتمبر) 1987 (المفارقة) نبيلة إبراهيم • المصباح المنير في غريب الثرح الكبير للرافعي ـ أحمد بن محمد بن علي المقري الفيومي ـ المكتبة العلمية - بيروت • مطلع القصيدة العربية ودلالته النفسية د ـ ـ عبد الحليم حفني ـ الهيئة المصرية العامة للكتاب 1987م • المعجم الأدبي ـ نواف نصار ـ دار ورد للنشر والتوزيع ـ الأردن ـ الأولى مع مابك 


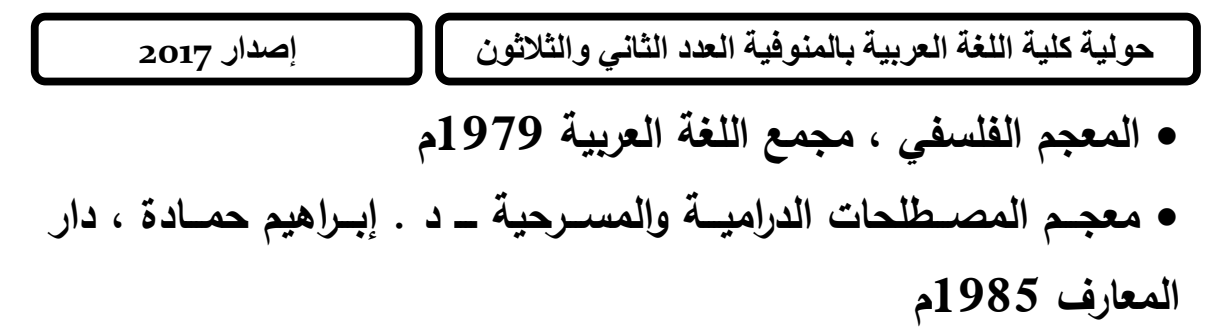

• معجم المصـطلحات العربيـة فـي اللغــة والأدب مجـدي وهبـة ، كامـل المهندس ـ مكتبة لبنان ، الثانية 1984 م

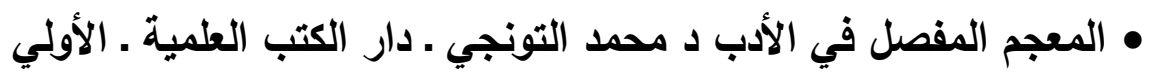
1993م

• المفارقة القرآنية د ــحمد العبد ـ دار الفكر العربي ، الأولي 1994م

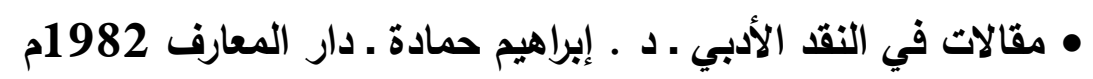

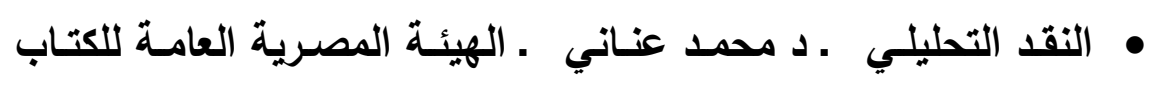
1991

• الوافي بالوفيات ـ صـلاح الدين خليل بن أيبك بن عبد الله الصفدي

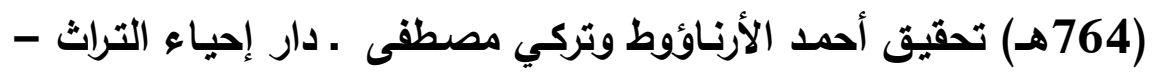

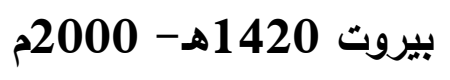




$$
\text { بـ عبدالميدمحد بلران }
$$

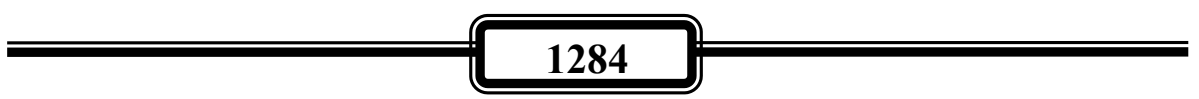




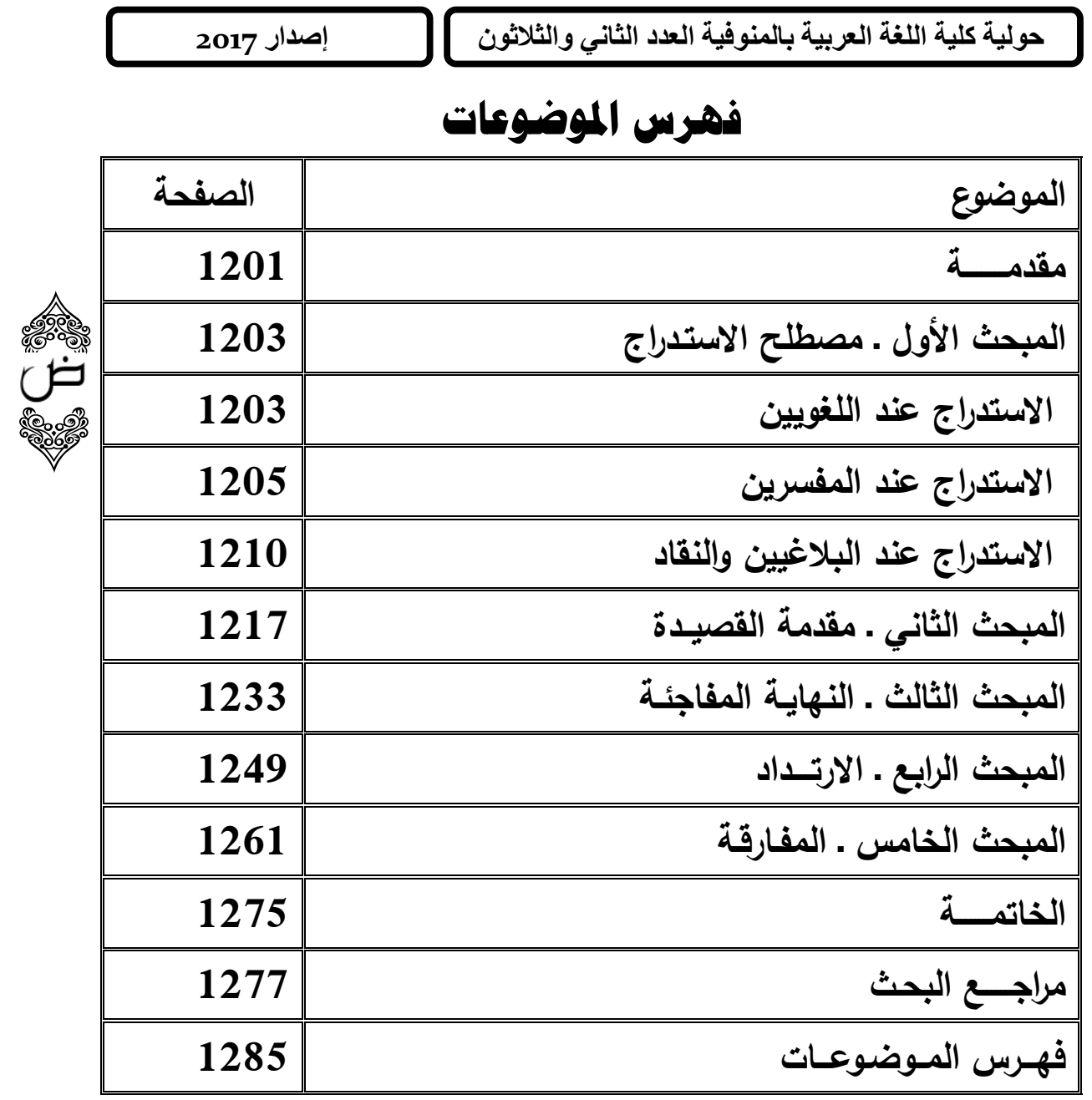




$$
\text { بـ عبدالميدمحد بلران }
$$

